\title{
p53 activity during adenovirus infection
}

\author{
Doctoral thesis \\ for the award of the degree \\ "Doctor of Philosophy (PhD)" \\ Division of Mathematics and Natural Sciences \\ of the Georg-August-Universität Göttingen
}

\author{
submitted by \\ Irina Savelyeva \\ from Saint-Petersburg, Russia
}

Göttingen 2009 
Referee: Prof. Dr. Ralf Ficner

Co-referee: Prof. Dr. Tomas Pieler

Date of the oral examination: 30.10.2009 
For my family 
2. INTRODUCTION 6

2.1. The tumour suppressor $\mathrm{p} 53 \quad 6$

2.1.1. $\mathrm{p} 53$ protein structure $\quad 6$

2.1.2. Biological functions of $\mathrm{p} 53 \quad 7$

$\begin{array}{ll}\text { Cell cycle arrest } & 7\end{array}$

Senescence $\quad 8$

Apoptosis $\quad 9$

2.1.3. Accumulation and activation of p53 by stress $\quad 10$

$\begin{array}{ll}\text { Stabilization of p53 } & 10\end{array}$

Activation and sequence-specific DNA binding of p53 12

The mechanisms of p53-activated transcription on the promoter of target genes 13

Regulation of p21 transcription by p53

2.1.4. Inactivation of p53 $\quad 15$

2.2. Adenovirus $\quad 17$

2.2.1. Structure of adenovirus genome. Virus life cycle. 17

2.2.2. Oncogenic potential of adenovirus $\quad 19$

$\begin{array}{ll}\text { 2.2.3. E1A proteins } & 20\end{array}$

2.2.4. E1B proteins 23

2.2.5. Adenovirus and cancer treatment. Oncolytic viruses. ONYX-015 24

$\begin{array}{lr}\text { 2.3. Aims of the study } & 25\end{array}$

3. MATERIALS AND METHODS $\quad 27$

$\begin{array}{lr}\text { 3.1. Materials } & 27\end{array}$

3.1.1. Technical devices $\quad 27$

3.1.2. Consumable materials $\quad 28$

3.1.3. Chemicals $\quad 29$

3.1.4. Enzymes $\quad 30$

3.1.5. Kits and reagents $\quad 31$

3.1.6. Buffers

3.1.7. Plasmids and vectors $\quad 36$

3.1.8. Oligonucleotides $\quad 36$

3.1.9. Antibodies $\quad 37$

3.1.10. Eukaryotic cell lines

3.1.11. Viruses

3.1.12. Cell culture working solutions $\quad 39$

3.2. Methods $\quad 40$

3.2.1. Cell biology $\quad 40$

Maintenance of cell cultures $\quad 40$

Cells freezing procedure $\quad 40$

3.2.2. Virology 41

Preparation of high titer viral stocks $\quad 41$

$\begin{array}{ll}\text { Virus titration } & 41\end{array}$

Infection of cells with virus $\quad 42$

3.2.3. Molecular Biology $\quad 42$

Total RNA isolation $\quad 42$

Quantification of RNA $\quad 42$ 
Purification of RNA

DNA digestion of RNA samples 43

Reverse transcription

Real-time PCR

3.2.4. Biochemistry and immunological methods 46

Immunoblot analysis $\quad 46$

Immunoprecipitation 48

Chromatin immunoprecipitation 49

$\begin{array}{ll}\text { Oligomerization studies } & 51\end{array}$

4. RESULTS

4.1. Mechanisms of p53 accumulation after infection with E1B-55 kDa-deleted viruses 53

4.1.1. p53 levels and activity in A549 cells after infection with E1B-55 kDa deletion mutants 53

4.1.2. p53 protein stability after infection with E1B-55 kDa deletion mutants 53

4.1.3. p53 protein stability after infection with E1A-deletion mutants 54

4.2. Mechanisms of p53 inactivation after adenovirus infection with E1B-55 kDa-deleted viruses 56

4.2.1. State of p53 in the infected cells 56

Intracellular localization $\quad 57$

Conformation
Oligomerization

Oligomerization
Phosphorylation at key serine residues

Phosphorylation at key serine residues $\quad 59$

4.2.2. Adenoviral and cellular proteins involved in p53 inactivation after infection 61

E1A-deletion mutants $\quad 61$

E1A-13S down-regulates p21 and mdm2 mRNA levels upon infection 62

E1A-13S inhibits pro-apoptotic Puma on the level of mRNA 65

E1A-13S blocks p21 gene expression at the level of transcription, rather than at the
posttranscriptional level

p53-binding to its DNA-elements in the p21 promoter does not depend on E1A-13S 66

E1A-13S is responsible for removing Sp1 and RNA polymerase II from the p21 promoter 67

Adenovirus blocks p53 acetylation at Lys382 residue, using aminoterminal portion of E1A protein

Blocking acetylation at Lys 382 is an additional way of inhibiting p53 activity by adenovirus, independent of E1A-13S

4.3. Restoration of p53 activity after infection

4.3.1. HDAC inhibitor TSA increases p21 transcription after infection with dl338 virus 71

4.3.2. TSA restores RNA polymerase binding to the p21 promoter start site 71

4.3.3. Adenovirus induces acetylation of $\mathrm{H} 3$ and $\mathrm{H} 4$ histones at p21 promoter 73

$\begin{array}{ll}\text { 5. DISCUSSION } & 75\end{array}$

5.1. Accumulation of p53 after infection with adenovirus 75

5.2. Inactivation of p53 after adenovirus infection 76

5.2.1. Inactivation of p53 through E1A-13S 77

5.2.2. Inhibition of p53 acetylation at residue Lys382 78

5.3. Posttranslational inactivation of p53 target gene products by E1A 79

5.4. Inactivation of p53 in the absence of adenovirus infection 79

5.5. Restoration of p53 activity after infection 81 
5.6. Evolutionary advantage for viruses with multiple mechanisms for p53 inactivation 


\section{Abstract}

Adenovirus is a small DNA tumour virus that has been extensively studied, leading to fundamental discoveries in molecular biology of mammalian cells. In particular, adenovirus oncoproteins were shown to inactivate cellular tumour suppressor pathways and this advanced our understanding of molecular mechanisms of cancer formation.

p53 is a key tumour suppressor that ensures cellular genomic integrity. Its function is impaired in most human malignancies, and DNA tumour viruses evolved multiple ways to block p53 activity in favour of productive virus infection. Human adenovirus type 5 codes for two oncoproteins, E1B-55 kDa and E4-34 kDa that bind and forward p53 to degradation in proteasomes. Deletion or mutation of E1B-55 kDa leads to a massive accumulation of the p53 protein in infected cells. Based on this fact, an idea of p53selective replicating oncolytic virus for cancer treatment was proposed. It was assumed that an infection of cancer cells containing mutant or null p53 with E1B-deficient virus should allow unrestricted virus replication and cell lysis. In contrast, normal cells, bearing wild type p53, were expected to block the replication of such virus mutants, since functional p53 should induce cell cycle arrest or apoptosis after infection. This attractive idea was implemented by the creation of an E1B-55 kDa-deleted oncolytic virus, designated ONYX-015. However, in spite of moderate successes in head and neck cancer treatment, ONYX-015 did not become a breakthrough in tumour therapy. As was shown by numerous studies later, E1B-deficient virus replication was independent of the cellular p53 status, though indeed, the virus replicated better in some cancer cells as compared to normal cells. The reason for ONYX-015 failure was understood on the molecular level, when p53 activity was carefully examined after infection. It became clear that, despite massive accumulation of p53, E1B-deficient virus blocked its transcriptional activity and thus prevented cell cycle arrest or apoptosis induction in the infected cells. Therefore, we speculated that, in addition to E1B-55 kDa, adenovirus evolved back up mechanisms of p53 inactivation that were investigated in this study. 
First of all, we show here that infection with E1B-defective adenovirus mutants induces massive accumulation of p53, without obvious defects in p53 localization, phosphorylation, conformation, and oligomerization. Nonetheless, p53 completely failed to induce its target genes, e. g. p21/CDKN1A, mdm2, and PUMA. Secondly, we found the adenovirus E1A proteins to be responsible for blocking p53 activity in the absence of E1B-55 kDa. Two regions of the E1A gene products independently contributed to p53 suppression. Depending on the E1A conserved region 3 (CR3), E1B-defective virus blocked transcription of p53 target genes, and impaired the ability of the transcription factor Sp1 to bind the $\mathrm{p} 21$ promoter. Moreover, the aminoterminal region of $\mathrm{E} 1 \mathrm{~A}$, binding the acetyltransferases p300 and CBP, blocked p53 K382 acetylation in infected cells. Mutating either of these $\mathrm{E} 1 \mathrm{~A}$ regions, in addition to $\mathrm{E} 1 \mathrm{~B}$, partially restored $\mathrm{p} 53$ activity. We conclude that adenovirus inactivates p53 by at least two E1B-independent mechanisms.

Thus, our study provides a mechanistic explanation why the lack of the E1B-55 kDa cannot be expected to result in p53-selective cytotoxicity. The mechanisms of p53 inactivation by E1A, described here, should be taken into account, when attempting to create p53-selective adenovirus for cancer therapy. Our findings may also help to understand the molecular mechanisms of p53 attenuation by other virus species and by virus-independent cancer cells. 


\section{Introduction}

Thirty years passed, since tumour suppressor p53 was discovered in 1979 by several research groups (DeLeo et al., 1979; Kress et al., 1979; Lane and Crawford, 1979; Linzer and Levine, 1979), and this opened a new chapter in cancer research. First of all, p53 is a key molecule to control DNA integrity of the cell. It represents a molecular detector, induced by genotoxic and cellular stresses. p53 determines the fate of the cell. According to the type and extent of DNA damage, it decides whether the cell should die or be repaired and continue to proliferate. In multicellular organisms, p53 is one of the molecules that control the integrity of the whole body, preventing the proliferation of cells that contain genetic abnormalities. The fact that the p53 gene is found mutated in $50 \%$ of all human cancers, and functionally inactivated in many others, makes it an attractive target for molecular and gene cancer therapy, as well as for cancer diagnosis and prognosis.

\subsection{The tumour suppressor p53}

\subsection{1. p53 protein structure}

In humans, the p53 gene is located on the short arm of chromosome 17 (Miller et al., 1986). It contains eleven exons. The structure of the 393-residue p53 protein is presented in Fig. 1. It includes two adjacent transactivation domains (TAD1, TAD2) near the $\mathrm{N}$-terminus. These interact with basal transcription factors but also with the regulator Mdm2. A proline-rich region (PRR) is responsible for multiple protein-protein interactions. The central DNA-binding domain (DBD) is frequently mutated in cancer. The DBD is followed by the oligomerization domain (TET), responsible for p53 tetramerization. p53 functionally acts as a transcription factor that binds to DNA in the form of two homo-dimers. 


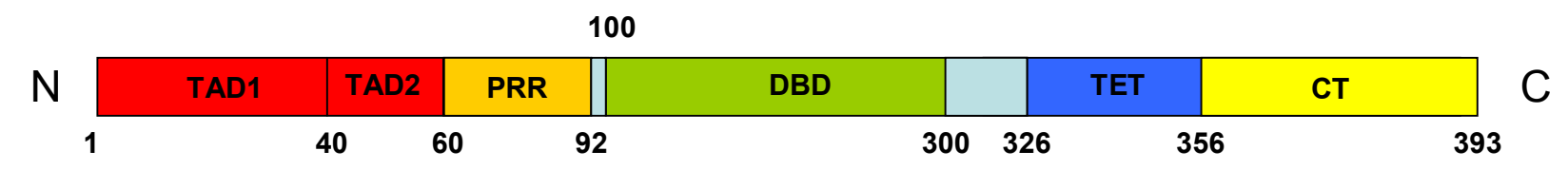

Fig. 1. The domain structure of the p53 protein. Human p53 is 393 amino acids long and has six domains: two transactivation domains (TAD1 and TAD2), proline-rich region (PRR), central DNA-binding core domain (DBD), oligomeritzation domain (TET), and C-terminal domain (CT).

\subsubsection{Biological functions of $p 53$}

\section{Cell cycle arrest}

The best-understood physiological consequences of p53 action are based on its transcription factor function in the nucleus. Many of the genes activated or repressed by p53 are categorized according to the response to p53 induction, such as cell cycle arrest genes, apoptotic genes, DNA-repair genes, senescence genes etc. (Fig. 2). Because of its high complexity, it is not clear, how exactly p53 signalling functions, but it is generally accepted that the cellular response to p53 activation depends on the cell type and the type/intensity of stress signals. In case of mild stress, for optimal repair of the damage, p53 inhibits cell proliferation in G1 phase before the cells enter a new cycle of DNA replication, or in $\mathrm{G} 2$ phase before they begin to divide. Therefore, there are two groups of G1- and G2-arrest genes that are being induced, correspondingly. The main player in a p53-inducible G1-arrest is an inhibitor of cyclin-dependent kinases (CDKs), p21/CDKN1A (later in the text p21). CDK4,6 and CDK2, together with their partners, cyclins, are the main regulators for initiation of DNA synthesis in S-phase. p21 blocks the onset of S-phase by binding to cyclin/CDK complexes and inhibiting their activities (Harper et al., 1995; Xiong et al., 1993). The G2-arrest-associated p53 target gene products GADD45, 14-3-30 and Reprimo also inhibit the activity of cyclin B/CDK1 


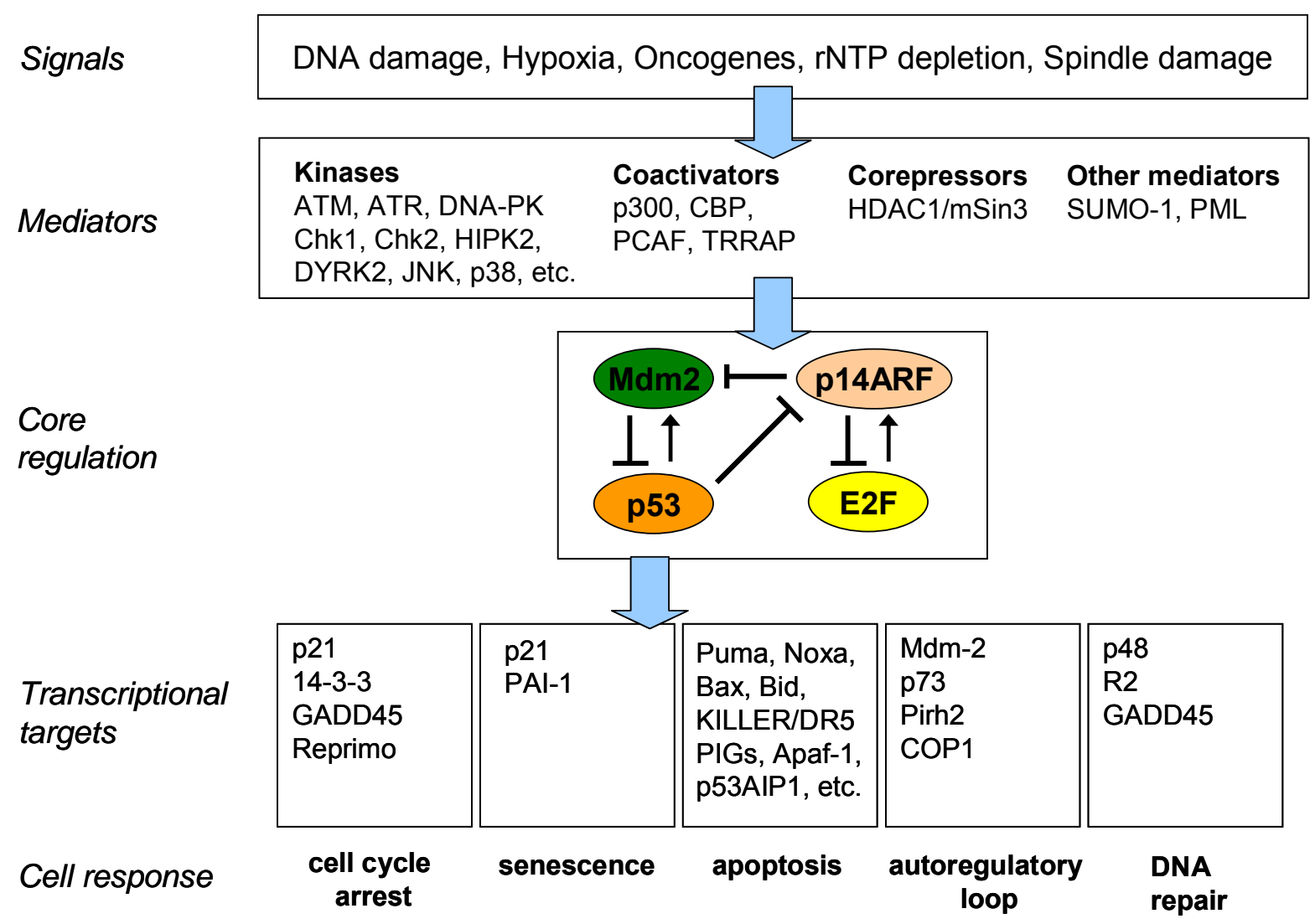

Fig. 2. Regulation of the p53 signalling. Activators, mediators and downstream targets. Figure from (Hainaut and Wiman, 2005), modified and expanded.

complexes that operate in G2 phase, and do not allow cells to enter mitosis (Laronga et al., 2000; Ohki et al., 2000; Zhan et al., 1999). Moreover, p53 represses the transcription of positive regulators of proliferation, e.g. CDK1 and cyclins B and D1, CDC25 (Krause et al., 2000; Rocha et al., 2003; Yun et al., 1999) to facilitate cell cycle arrest.

\section{Senescence}

Inducing cell cycle arrest is an important, but not the only duty of the p53 as a tumour suppressor. A transient block of proliferation may be insufficient, leading to the survival of cells with unrepaired DNA damage that can be potentially oncogenic. In this case, the cells undergo either irreversible cell cycle arrest, called senescence, or apoptosis programmed cell death. The phenomenon of senescence was first observed in cell culture as so called 'replicative senescence' that is caused by the shortening of chromosome ends (telomeres) (Olovnikov, 1971; Olovnikov, 1973). Only recently, it was 
understood that apparently telomere shortening could be perceived as a non-reparable DNA-damage by the p53 pathway. It was found that telomere dysfunction as well as DNA damage and oncogene signalling induce p53 to activate transcription of several senescence-initiating genes, e.g. p21 and PAl-1 (Brown et al., 1997; Kortlever et al., 2006). Several recent animal experiments have proven the role of p53-induced senescence in tumour suppression in vivo (Deng et al., 2008).

\section{Apoptosis}

Apoptosis is a programmed cell death that is induced by cellular stresses and is accompanied by cell shrinkage, membrane blebbing, chromatin condensation, fragmentation of nuclei and DNA. Apoptosis clearly represents a tumour suppressor function of p53 and eliminates potentially harmful precancerous cells. Pro-apoptotic p53 target genes are implicated in different death signalling pathways, operating both on intrinsic (mitochondria) and extrinsic (death receptors) cellular levels as well as in endoplasmic reticulum. All three pathways intercross and converge to activate aspartate-specific cysteine proteases (caspases) for degradation of cellular organelles and subsequent cell death.

Mitochondrial mediated apoptosis is mainly induced after DNA damage, ischemia and oxidative stresses. It starts with the permeabilization of the mitochondrial outer membrane, followed by the release of apoptogenic molecules of intermembranal space (cytochrome $\mathrm{C}$, apoptosis inducing factor AIF, etc.) into the cytoplasm, activation of caspases and subsequent cell death. p53 protein is involved in mitochondrial apoptotic process on multiple levels. First of all, it activates the transcription of pro-apototic genes, e.g. Bax (Miyashita et al., 1994b) Bid (Sax et al., 2002), Noxa (Oda et al., 2000a), PUMA (Nakano and Vousden, 2001; Yu et al., 2001), Apaf-1 (Kannan et al., 2001; Moroni et al., 2001), p53AIP1 (Oda et al., 2000b). Apart from the activation of transcription, p53 represses the transcription of anti-apoptotic factors, e.g. Bcl-2, Bcl-xL and Survivin (Hoffman et al., 2002; Miyashita et al., 1994a; Sugars et al., 2001). In some cell types, p53 may induce apoptosis in a transcription-independent manner. It was shown that after cell damage, p53 rapidly translocates to mitochondria, where it binds to the antiapoptotic Bcl-xL and Bcl-2 proteins, induce oligomerization of Bak, permeabilization of 
the outer membrane and promotes cytochrome C release (Mihara et al., 2003; Mihara and Moll, 2003).

p53-activated cell death is predominantly executed via mitochondria. However, p53 may also induce apoptosis interfering with death receptor pathway, inducing the transcription of death receptors as Fas, KILLER/DR5 and p53RDL1 (Takimoto and El-Deiry, 2000; Tanikawa et al., 2003; Wu et al., 1997), increasing the sensitivity of cells to the death ligands. Death receptors conduct the apoptotic signals from the membrane to the cytoplasm and induce caspase-8 mediated cleavage of Bid protein, thus connecting the extrinsic to intrinsic mitochondrial apoptotic pathway. Apart from activating Bid expression, as was mentioned before, p53 transactivates caspases such as caspase 6 and 10 (MacLachlan and El-Deiry, 2002; Rikhof et al., 2003). In addition, p53 induces apoptosis in endoplasmic reticulum via its target gene Scotin after DNA damage (Bourdon et al., 2002), and possesses an ability negatively regulate survival PI3K pathway (Singh et al., 2002; Stambolic et al., 2001). Thus, the regulation of apoptosis by p53 is very complex and is controlled at multiple levels.

\subsubsection{Accumulation and activation of p53 by stress}

p53 is expressed at low levels at normal conditions. A traditional model, describing p53 activation after cellular stress, includes three steps: p53 stabilization, sequence specific DNA-binding to the promoters of the target genes, and subsequent activation of their transcription by interacting of p53 with the general transcription machinery.

\section{Stabilization of p53}

It is generally accepted that p53 expression is mostly regulated post-translationally. In unstressed cells, p53 is poorly expressed, because of having a high turnover; its half-life is around 30 minutes depending upon the cell type (Oren et al., 1981; Stommel and Wahl, 2004). Low levels of p53 protein are maintained by binding to E3-ubiquitin ligases. Mdm2 is considered to be the major endogenous E3-ligase for p53 (Haupt et al., 1997; Honda et al., 1997; Kubbutat et al., 1997). This idea is supported by in vivo genetic studies that showing that embryonic lethality due to Mdm2 loss can be completely 
rescued by additional loss of p53 (Jones et al., 1995; Montes de Oca Luna et al., 1995). Mdm2 binds to a N-terminal region of p53 (minimal binding site within residues 18-26) and, when present in low levels, promotes mono-ubiquitination of p53 near its Cterminus, resulting in the export of p53 from the nucleus (Lohrum et al., 2001; Marchenko et al., 2007). High levels of Mdm2, together with p300, induce polyubiquitination that targets p53 for proteasomal degradation (Grossman et al., 2003; Li et al., 2003). However, Mdm2 is not the only E3-ligase for p53, since p53 is still degraded in the cells of Mdm2 null mice (Ringshausen et al., 2006). Indeed, recently novel E3ligases such as Cop1, Pirh2 and ARF-BP1 were found to contribute to the p53 degradation (Chen et al., 2005; Dornan et al., 2004; Leng et al., 2003). Interestingly, Mdm2, COP1 and Pirh2 are themselves transcriptionally induced by p53, establishing a negative feedback loop.

As soon as a cell undergoes stress (DNA-damage, UV-irradiation, oncogenic stress, hypoxia etc.), rapid nuclear accumulation and subsequent activation of p53 occurs. The stabilization of p53 is thought to result in the first place from the disruption of the p53Mdm2 interaction. Some oncogenes, for example, induce the expression of p14ARF, that binds Mdm2 and sequesters to the nucleoli (Weber et al., 1999). The N-terminal phosphorylation of p53 after DNA damage was shown to stabilize p53 by inhibiting its interaction with Mdm2. So far, 17 residues on the p53 molecule were found to be phosphorylated upon DNA damage (Fig. 3). The best examples that were shown to disrupt the p53-Mdm2 complex are phosphorylations at Ser15, Ser20 and Thr18, by the kinases ATM, ATR, DNA-PK, Chk1/2 and CK2, in response to ionizing radiation and UVirradiation (Appella and Anderson, 2001; Shieh et al., 2000; Shieh et al., 1997). Small chemical molecules Nutlin-3a and MI-219, also prevent Mdm2-p53 binding, stabilize and activate p53, making them attractive candidates for cancer therapy (Shangary et al., 2008; Vassilev et al., 2004). 


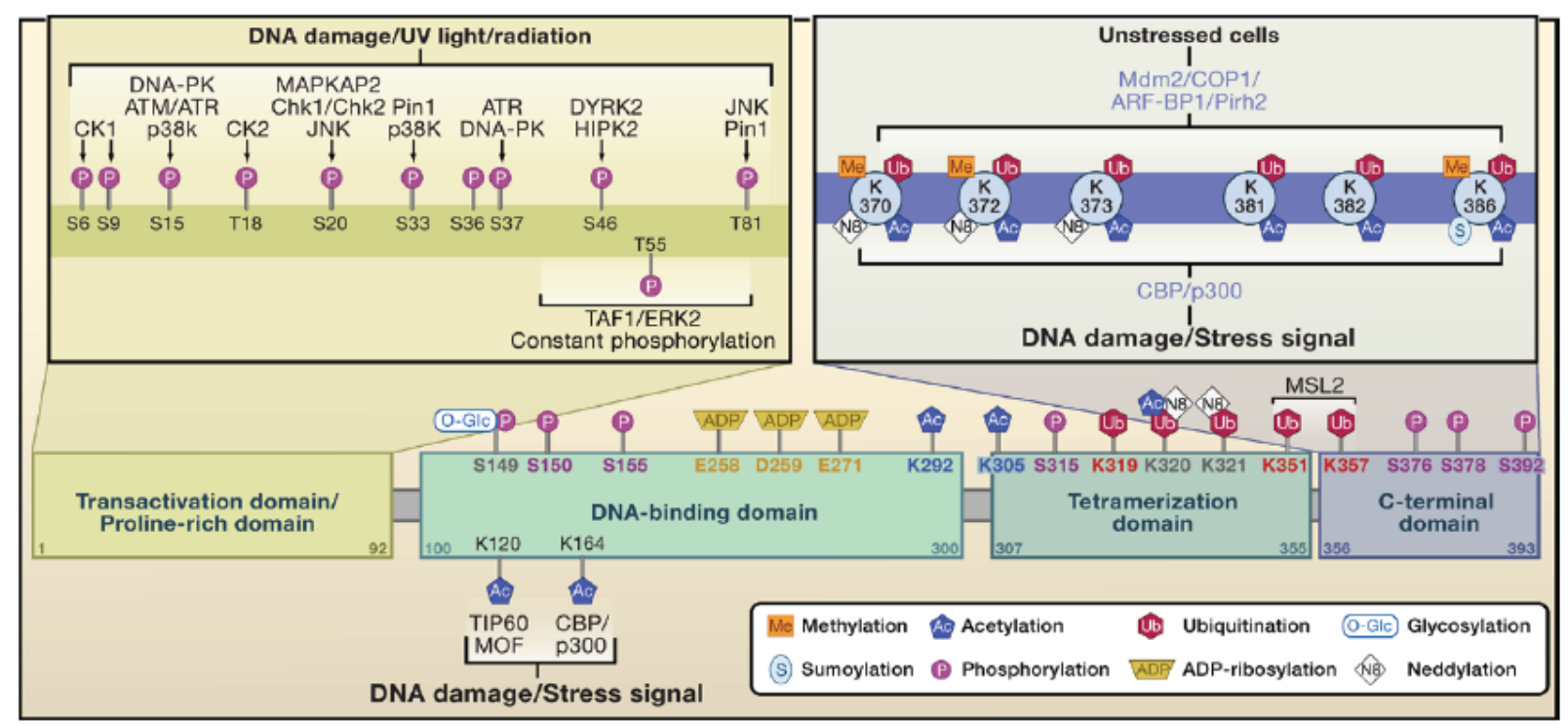

Fig. 3. Overview of the p53 posttranslational modifications. More than 36 amino acids of p53 are reported to be modified. The major sites of p53 phosphorylation (P), ubiquitination (Ub), and acetylation (Ac) are shown with the corresponding major modifying enzymes and signals. Furthermore, additional phosphorylation and acetylation sites, as well as major sites of methylation (Me), sumoylation (S), neddylation (N8), glycosylation (O-Glc) and ribosylation (ADP), are indicated. Figure from (Kruse and Gu, 2009).

There is probably an additional way of stabilizing p53 after stress without disrupting the Mdm2-p53 interaction. It is possible that DNA-damage induces the acetylation of the Cterminal portion of p53 at the same residues that are ubiquitinated by Mdm2 (Lys320, Lys370, Lys372, Lys373, Lys381 and Lys382). This may contribute to stabilization of p53 (Fig. 3). Transient transfection studies showed that simultaneous Lys to Arg mutations at these six residues (6KR p53 mutant) conferred resistance to Mdm2mediated ubiquitination and degradation (Rodriguez et al., 2000). However, 6KR mutant knock-in mice showed normal p53 stabilization before and after DNA-damage, suggesting that additional E3-ligases as well as ubiquitination of the other p53 lysines are implicated in the regulation of p53 stability in vivo (Feng et al., 2005).

\section{Activation and sequence-specific DNA binding of p53}

One of the first ideas about the function of p53 came from the observation of its sequence specific DNA binding ability. p53 binds as a 'dimer of dimers' to two half-sites 
on promoter DNA of its target genes with a sequence 5'-Pu-Pu-Pu-CA/TA/TG-Py-PyPy-3' separated by 0-13 bases (el-Deiry et al., 1992), and induces the transcription of these genes. The importance of sequence-specific DNA-binding for p53 activity is supported by the notion that the majority of tumorigenic mutations is located in the DNAbinding domain of p53 (Hainaut and Hollstein, 2000). The sequence-specific binding is regulated by the C-terminal portion of p53 through the last basic 30 amino acids. Several studies support the idea that acetylation may increase p53 DNA-binding to its target elements both in vivo and in vitro, apparently through a conformational change in the p53 tetramer (Gu and Roeder, 1997; Liu et al., 1999; Luo et al., 2004; Sakaguchi et al., 1998). In contrast, structural studies showed that wild type p53 and basic domain deletion mutants of p53 have the same structure (Ayed et al., 2001), and ChIP analysis detected that acetylation mutants of p53 (K320R, K373R, K381R and K382R) bind to the p21 promoter to a similar extent as wild type p53 (Barlev et al., 2001). Therefore, the role of acetylation, as well as phosphorylation and sumoylation, in p53-DNA binding is still under investigation. But it is clear that induction of all these modifications of p53 after DNA damage strongly correlate with p53 activation and stabilization (Ito et al., 2001; Knights et al., 2006; Luo et al., 2000; Melchior and Hengst, 2002).

Posttranslational modification seems to partially determine the promoter selectivity for p53. Thus, for example, acetylation at Lys120 in the DNA-binding domain of p53, mediated by hMOF and TIP60 acetyltransferrases after severe DNA-damage, is essential for activation of pro-apoptotic genes Bax and PUMA and is not required for p21 and $m d m 2$ induction (Sykes et al., 2006; Tang et al., 2006). The phosphorylation of Ser46 by the kinases HIPK2 (D'Orazi et al., 2002) or DYRK2 (Taira et al., 2007) is necessary for selective activation of the pro-apoptotic p53AIP1 gene (Oda et al., 2000b).

\section{The mechanisms of p53-activated transcription on the promoter of target genes}

Several dozen of p53-responsive genes have been already identified, but the mechanisms of how p53 activates transcription after binding to its target promoters are still unclear. Some studies show that p53 may stimulate transcription by recruitment of basal transcription factors as TFIIA and TFIID or facilitate transcription preintiation complex formation via interaction with components of the mediator complex (Gu et al., 
1999; Liu et al., 1993; Seto et al., 1992; Thut et al., 1995; Truant et al., 1993; Zhang et al., 2005). The other groups claim that p53-binding to its DNA-elements helps to recruit chromatin remodelling factors or histone acetyltransferase complexes, including p300/CBP, TRRAP, Tip60 and/or methyltransferases PRMT1 and CARM1, to the promoters of target genes (An et al., 2004; Avantaggiati et al., 1997; Barlev et al., 2001; Lee et al., 2002; Lill et al., 1997). This leads to the modifications of histones, chromatin rearrangement and opening of the promoter to general transcription factors and RNApolymerase (Goodman and Smolik, 2000).

\section{Regulation of $\mathrm{p} 21$ transcription by $\mathrm{p} 53$}

One of the most well characterized p53-activated genes encodes the CDK-inhibitor p21. p21 is a ubiquitously expressed protein that is involved in cell cycle regulation, terminal differentiation, and senescence. It was identified by association with CDK complexes and PCNA, a processivity factor for DNA polymerase $\delta$ (Harper et al., 1993; Zhang et al., 1993). Accumulation of p21 after stress stimuli leads to the inhibition of cyclin/CDK activities, hypophosphorylation of $\mathrm{pRB}$, inactivation of E2F transcription factors and subsequent G1-arrest (Brugarolas et al., 1999; Dulic et al., 1994). Stress-response studies showed p21 transcription to be strongly activated by p53 (el-Deiry et al., 1994; el-Deiry et al., 1993). However, many differentiation-promoting agents, like TGF- $\beta$, butyrate, NGF, and the histone deacetylase inhibitor TSA, induce p21 transcription in a p53-independent manner (Gartel and Tyner, 1999). In the latter case, p21 transcription is activated by the transcription factors $\mathrm{Sp} 1$ and $\mathrm{Sp} 3$ that bind to the proximal promoter region between positions -120 and -50 upstream of the transcription start site (Sowa et al., 1997). It was also shown that p53 and Sp1 may cooperate in activation of p21 transcription after some DNA-damaging agents in human and Drosophila melanogaster cells (Koutsodontis and Kardassis, 2004; Koutsodontis et al., 2001; Koutsodontis et al., 2005; Lagger et al., 2003). 


\subsubsection{Inactivation of $\mathrm{p} 53$}

p53 is probably the most well-known tumour supressor gene, because it is inactivated by mutations (missense and nonsense mutations or nucleotide insertions/deletions) in more than $50 \%$ of all human cancers. In the other $50 \%$, p53 is functionally impaired, resulting in cancer cell proliferation. The consequence of p53 mutations is the absence of protein (10\% of cases) or accumulation of mutant p53 (90\% of cases). Mutant p53 may act either in a dominant-negative fashion, inactivating the second wild type copy of p53 if it exists, or enhance the tumorigenic potential of cells lacking wild type p53 (gain of function).

Most of the cancerogenic mutations occur in the DNA-binding domain of p53 (Hainaut and Hollstein, 2000). About $40 \%$ of all p53 mutations concentrate in 6 hot spots at codons Arg175, Gly245, Arg248, Arg249, Arg273, Arg282. Structural studies have shown that these residues are critical for p53-DNA ineractions, either by direct contact with DNA $(248,273)$ or by stabilizing the DNA-binding surface $(175,249,282)$. Therefore mutants can be roughly divided into two groups - contact mutants and conformational mutants. It was shown that some p53 mutants acquire an ability to bind other proteins and promoters than wild type p53, inducing transcription of genes that contribute to cancerogenesis. Another class of mutations in the DBD leads to complete destabilization of the p53 protein. p53-inactivating mutations also occur in the oligomerisation domain. For example, in Li-Fraumeni or Li-Fraumeni-like syndromes, p53 is affected by germline mutations in tetramerisation domain, and this leads to full or partial loss of p53 activity (Lomax et al., 1998).

In the other half of tumours, bearing an intact p53 gene, the protein is functionally blocked by diverse mechanisms. Most of them involve regulators of p53 induction, the target genes of $\mathrm{p} 53$, or components of downstream signalling, affected by the products of these target genes. The most well characterised case is enhanced degradation of p53 by the Mdm2 protein, either because of $m d m 2$ gene amplification (in 30\% of sarcomas, (Taubert et al., 2003)) or due to the loss or epigenetic inactivation of the p14arf gene 
that negatively regulates the binding of p53 to Mdm2 (Chin et al., 1998). Amplification of WIP-1 phosphatase that inhibits activating phosphorylation of p53 was shown to reduce p53 activity (Bulavin et al., 2002). The other way of p53 inactivation implemented by cancer cells is sequestering p53 in cytoplasm. Neuroblastoma cell lines mediate cytoplasmic relocalisation of p53 at least by two proteins - Parc (Parkin-like ubiquitin ligase) and glucocorticoid receptor that bind to p53 and serve as its cytoplasmic anchor (Nikolaev et al., 2003; Sengupta et al., 2000).

p53 function is also antagonized by viruses. Being intracellular parasites, viruses reorganize the host cell replication/translation machinery to favour effective production of viral progeny. This usually results in unrestricted proliferation of infected cells that is recognised as a potentially cancerogenic situation by p53. Activation of p53-signaling is non-beneficial for virus propagation, because of a danger of preliminary apoptosis induction. Therefore, viruses encode proteins that bind to and inactivate p53 through different mechanisms. p53 was first identified in the complex with large T-antigen of simian vacuolating virus 40 (SV40 T-ag) that inhibits p53 transcriptional activity (Lane and Crawford, 1979; Linzer and Levine, 1979). Human papilomavirus (HPV type 16 and 18) E6 protein, by forming a triple complex with the E3 ubiquitin ligase E6AP and p53, promote p53 degradation (Huibregtse et al., 1991; Scheffner et al., 1992; Scheffner et al., 1990). Also, HPV E6 was shown to repress p53-mediated transcriptional activation independently of E6AP through inhibition of p300-mediated acetylation (Thomas and Chiang, 2005). Adenovirus, to which the following chapter is devoted to, inactivates p53 by means of the E1B-55 kDa and E4ORF6 proteins, by initiating p53 degradation in proteasomes. Human herpes virus 8 protects the infected cells from dying, expressing LANA protein that inhibits p53 by binding to it (Friborg et al., 1999). DNA-tumor viruses may also inactivate p53 indirectly, for example, inhibiting p14ARF-mediated induction of p53, as mouse polyoma virus does (O'Shea and Fried, 2005). 


\subsection{Adenovirus}

\subsubsection{Structure of adenovirus genome. Virus life cycle.}

Adenovirus, a small DNA tumor virus, belongs to the Adenoviridae family of viruses, which includes around 50 human adenovirus serotypes, divided into six subgroups (type A to F). It has a non-enveloped ecosahedral capsid, consisting of three main proteins hexon (II), penton base (III) and knobbed fibre (IV) and several minor ones (V, VI, VII, VIII, IX, IIla and IVa2) (Fig. 4). The viral capsid contains a linear double-stranded 36kb DNA, protected by the terminal protein, covalently linked to the $5^{\prime}$ ends (Rekosh et al., 1977).

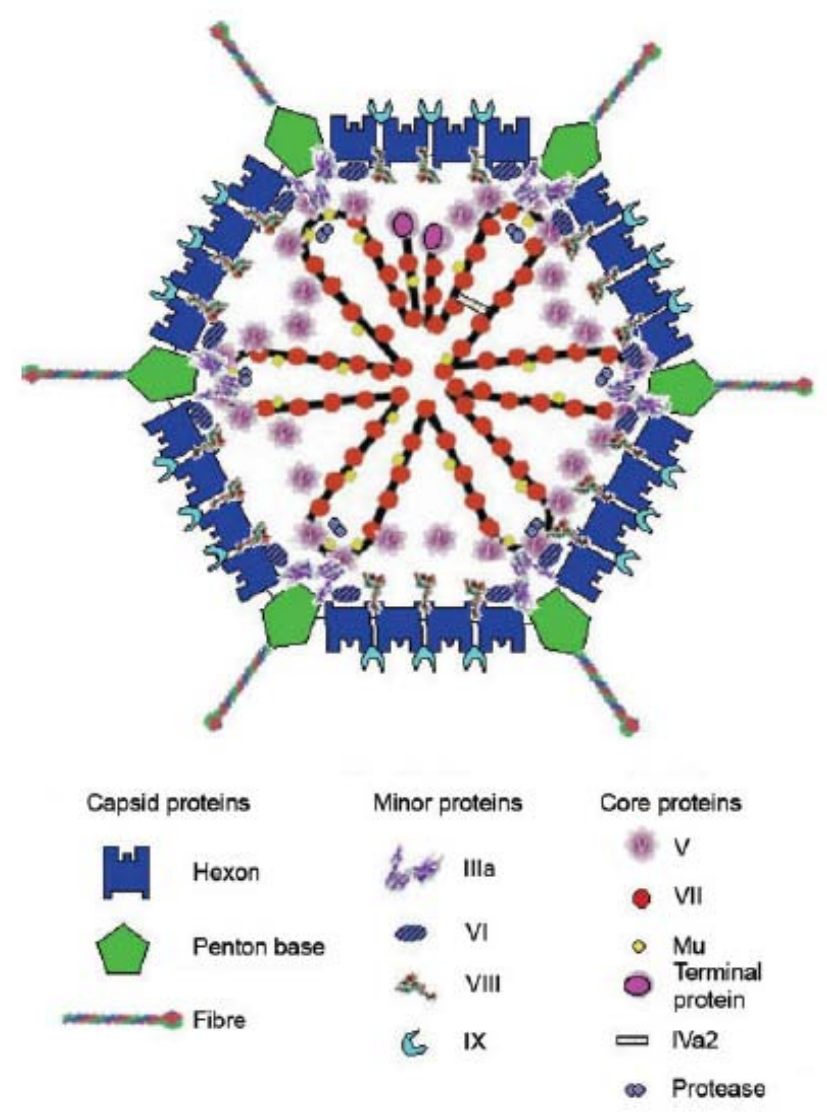

Fig. 4. Structure of adenovirus. A schematic depiction of the adenovirus structure, based on cryo-electron microscopy and crystallography. Double-stranded DNA of adenovirus (black line) with DNA-associated core proteins (V, VII, Mu, IVa2 and the terminal protein TP) is packed into an icosahedral capsid, consisting of three major proteins, hexon, penton base and knobbed fibre, and number of minor proteins (IIla, VI, VIII, IX). Figure from (Russell, 2009). 
Members of the adenovirus family infect a great variety of quiescent cells, even from highly differentiated tissues, e.g. lung, brain, heart, and sceletal muscles. The infection cycle of adenovirus is divided into two phases, early and late, occuring before and after DNA replication, respectively. The early phase begins with binding of adenovirus through the knob domain of the fiber protein to the receptor on the cell surface (CD46 for the group $B$ human adenovirus and coxsackievirus/adenovirus receptor CAR for the other serotypes). After intracellular internalization, the virion migrates to the nucleus via microtubules. Its DNA enters the nucleus through nuclear pores, where it is converted into a cellular histone complex, followed by selective transcription and translation of the early virus genes. The early region of the adenovirus genome contains four 'cassettes', named E1, E2, E3 and E4 (Fig. 5). First, the E1A gene of the E1 region is expressed. E1A proteins are responsible for the stimulation of DNA synthesis and transactivation of the other members of early regions, E1B, E2, E3 and E4. The products of the E1B gene, E1B-19 $\mathrm{kDa}$ and E1B-55 kDa, are anti-apoptotic proteins that block premature cell death, otherwise induced by the infection. The E2 cassette mediates virus replication and codes for E2A DBP (DNA-binding protein) and for two products of the E2B region the precursor of terminal protein PTP and DNA polymerase Pol. E3 genes are nonessential for viral replication in cell culture. Together with a set of non-translated VA RNAs, E3 proteins combat the immune defence mechanisms of the organism (blocking interferon activity and MHC class I translocation). The gene products of the E4 region mainly function to regulate virus mRNA metabolism, and to fulfil the host protein synthesis shut-off, often acting together with E1B proteins.

Synthesis of viral DNA begins as soon as all components essential for replication are expressed or recruited. The terminal protein, covalently bound to the 5 ' end of the adenovirus genome, serves as a primer for replication, which is mediated by the viral DNA polymerase by strand displacement mechanism. Virus production is finished in the late phase that is focused mostly on expressing structural proteins for the capsid, assembling viral particles, and induction of cellular lysis. 


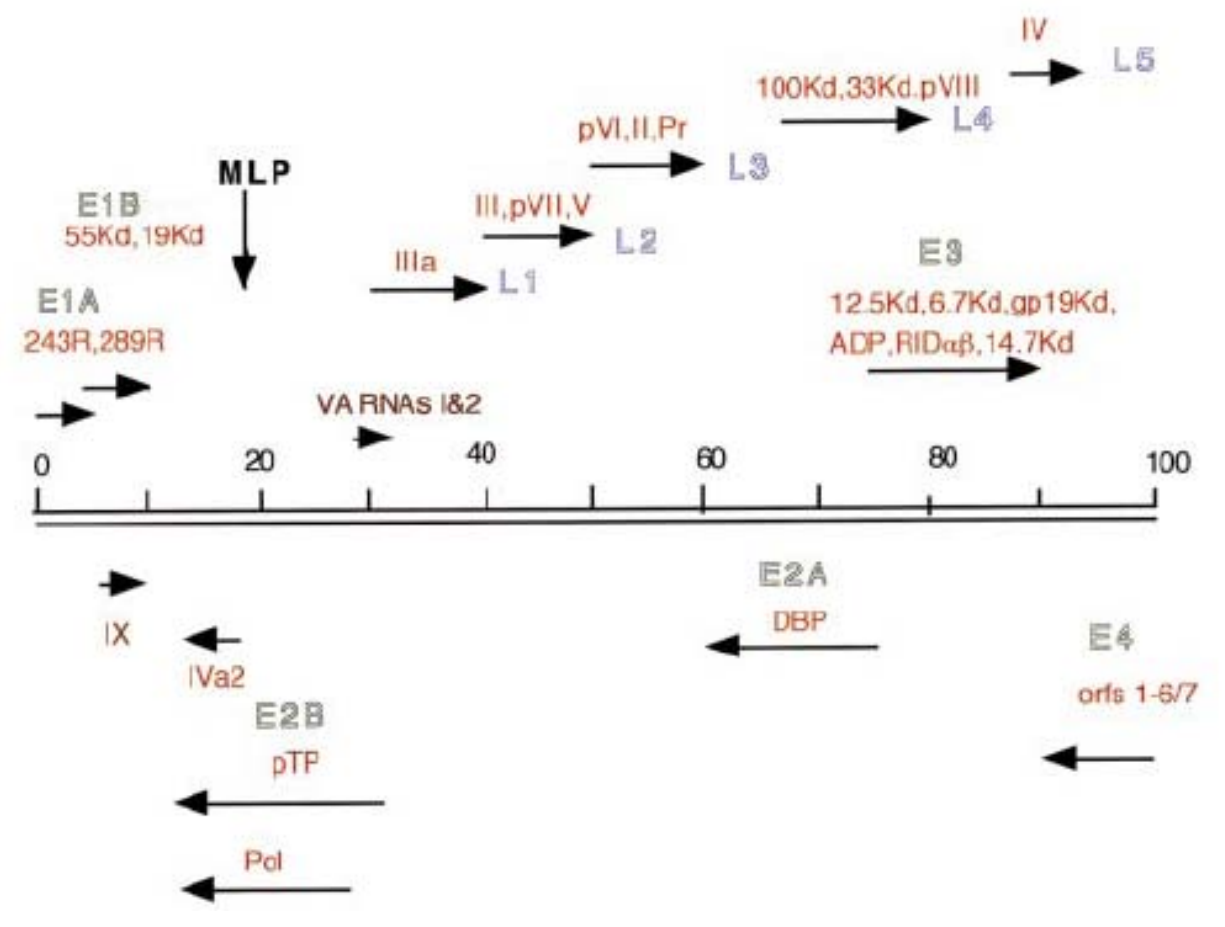

Fig. 5. Transcription of the adenovirus genome. E1A, E1B, E2A, E2, E3, E4 - early transcripts. L1-L5 - late transcripts. MLP, Major late promoter. Figure from (Russell, 2000).

\subsubsection{Oncogenic potential of adenovirus}

Viruses and tumor cells have much in common. Their final goal is to drive unlimited proliferation of cells that, in the case of the virus, is required for the maximum production of progeny virions. Adenoviruses, though having no tumorigenic potential in humans, are capable to induce cancer in immunodeficient nude mice, and some serotypes form tumours in newborn hamsters (Trentin et al., 1962). These cancerogenic abilities are mediated by adenoviral proteins that interfere with cell proliferation and tumor suppression signalling pathways. Therefore, adenovirus represents an important model system for cancer research. Most of the work concerning adenovirus and cell cycle control was performed using Ad type $2 / 5$ or Ad type 12 . Here we will mostly refer to human Ad type 5, because it was used in this work. 
First studies of adenovirus transforming potential were carried out in cultured rodent cells. They allowed identification of the virus genes responsible for cellular transformation. It was shown that introduction of the adenoviral $E 1 A$ region into rat fibroblasts is sufficient to induce repeated entry of cells into S-phase and to drive cell immortalization (Kaczmarek et al., 1986). However, E1A expression alone resulted in massive apoptosis and abortive transformation (Debbas and White, 1993; Houweling et al., 1980; Lowe and Ruley, 1993; Teodoro et al., 1995). Full oncogenic transformation occurred only in the case of co-expression of E1A and another cooperative oncogene, e.g. adenovirus $E 1 B$ or the cellular Ras oncogene (Byrd et al., 1988; Graham et al., 1974; Lin et al., 1995; Ruley, 1983).

\subsubsection{E1A proteins}

E1A is a first viral transcription unit to be transcribed in the first hour after infection with Ad type 2/5. It produces a transcript that is processed by alternative splicing into five mRNAs. Two of them, with sediment coefficients $13 \mathrm{~S}$ and $12 \mathrm{~S}$, encode the large E1A $289 \mathrm{R}$ protein and the small E1A $243 \mathrm{R}$ protein, respectively. Basically, all known biological functions of E1A are carried out by these two proteins; the other three (11S (217R), 10S (171R) and 9S (55R)) accumulate later during the early phase of infection.

Adenoviral $13 S$ and $12 S$ mRNAs encode identical proteins, except 46 amino acids referred to as CR3, unique to E1A-13S. Comparison between the serotypes identified four highly conserved regions CR1, CR2, CR3 and CR4 (Fig. 6), separated by less conserved domains. These domains are required for the interaction with cellular factors and are critical for E1A function. E1A are predominantly nuclear proteins, do not possess any known enzymatic activity, and function mainly as regulators of transcription by binding to multiple cellular proteins.

During infection, adenovirus navigates the cellular machinery in the direction of effective replication, transcription and translation of virus genome. This is believed to be mediated by several mechanisms. First of all, E1A proteins bind to the negative regulators of the cell cycle, i.e. the retinoblastoma protein pRB (p105) and pRB-related family members p107 and p130 (Ewen et al., 1991; Li et al., 1993; Whyte et al., 1988). These proteins contain several domains, including the highly conserved domains $A$ and $B$ that together 
with a linker domain form a 'pocket' that is critical for their tumour suppression function (Qin et al., 1992; Zheng and Lee, 2001). With their 'pocket', pRB family proteins were shown to bind and inhibit the activity of transcription factors of E2F family (Hiebert, 1993; Hiebert et al., 1992; Qin et al., 1992). The latter control the entry into S-phase, inducing transcription of genes required for DNA synthesis. The $\mathrm{pRb}$ protein binds E2Fs on the promoters of their target genes and inactivates them, apparently through masking their transactivation domains and recruiting co-repressors, including but not limited to histone deacetylase HDAC1 (Luo et al., 1998).

pRB activity is regulated by phopshorylation. In early $\mathrm{G} 1$ phase, pRB is present in a hypophosphorylated repressive form. Upon mitogenic stimulation, $\mathrm{pRb}$ becomes phosphorylated by cyclin-kinase complexes, leading to the dissociation of E2F factors and subsequent S-phase entry (Sherr, 2000; Zheng and Lee, 2001). E1A were shown to release $\mathrm{E} 2 \mathrm{~F}$ from repression by $\mathrm{pRb}$. In the currently accepted model, E1A competes for $\mathrm{E} 2 \mathrm{~F}$ binding to $\mathrm{pRB}$, thereby releasing active E2F factors (Ghosh and Harter, 2003). E1A mediates this first by binding to the 'pocket' of pRb family members via the $L x C x E$ sequence in CR2, and then displacing pRB from E2F by CR1 (Fattaey et al., 1993). Additionally, E1A proteins bind and block the activity of the CDK inhibitors p21 and p27, stimulating cell division (Keblusek et al., 1999).

The other way of deregulating the cell cycle in favour of virus production is an ability of E1A to interact with and modulate the activity of different host cell proteins that function as transcription factors (e.g. ATF-2, YY1, Sp1), co-activators (p300/CBP, PCAF) and corepressors (CtBP), chromatin remodelling factors (SWI/SNF member p400), components of the general transcription machinery (TBP, TAFs) and mediator complex (MED23) (depicted in Fig. 6) (Ben-Israel and Kleinberger, 2002; Berk, 2005; Frisch and Mymryk, 2002; Gallimore and Turnell, 2001). This allows E1A to selectively activate or repress transcription of cellular and viral genes, though the exact mechanisms are still not clear. As a consequence of its action, E1A promotes apoptotic cell death in p53independent, as well as in p53-dependent fashion (Lin et al., 1995; Putzer et al., 2000; Teodoro et al., 1995). The latter was shown to correlate with p53 stabilization after transfection of cells with E1A, though nobody carefully looked, whether this apoptosis 


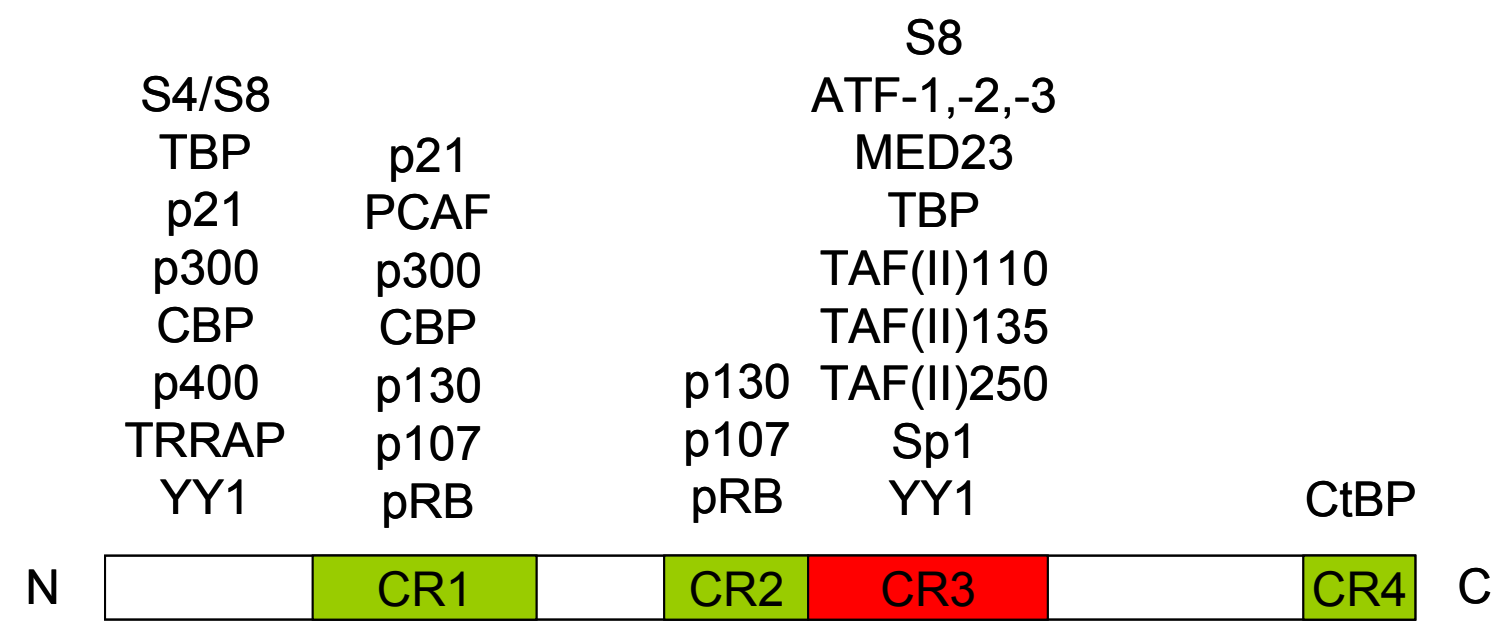

Fig. 6. Large E1A-13S protein and its cellular interaction partners. Domain structure of the large 289R E1A protein. CR1-4 - concerved regions 1-4. Numerous cellular proteins physically interact with E1A, including transcriptional activators and repressors (ATF, Sp1, YY1, CtBP), components of basal transcription machinery and mediator complex (TBP, TAFs, MED23), chromatin modifiers ( $\mathrm{p} 300 / \mathrm{CBP}, \mathrm{PCAF}, \mathrm{p} 400)$ ), cell cycle regulators ( $p R B, p 130, p 107, p 21)$, and components of proteasome (S4, S8).

induction required transcriptional activation of apoptotic genes by p53 or not (Lowe and Ruley, 1993). The mechanisms of p53 stabilization after E1A expression are still debated. It is assumed that E1A does not bind p53 directly, since no such interaction has been reported. Therefore, E1A appears to interfere with a system that controls p53 turnover. It is possible that interaction and inhibiting of the proteasome subunits by E1A may result in p53 accumulation, as it was suggested by co-transfection experiments (Turnell et al., 2000; Zhang et al., 2004).

Taken together, E1A proteins represent a powerful tool for deregulation of cellular signalling after infection. However, the precise mechanisms of their action require deeper investigation. Also, most of the obtained data come from transfection assays that may only partially reflect the physiological situation. Therefore, infection systems are of special interest in this regard. 


\subsubsection{E1B proteins}

The E1B region of the adenovirus genome encodes two proteins, E1B-55 kDa and E1B$19 \mathrm{kDa}$. E1B proteins contribute to E1A-mediated cellular transformation, antagonizing undesirable apoptosis. The small E1B-19 kDa protein is a structural homologue and may also functionally replace the anti-apoptotic $\mathrm{Bcl}-2$ protein. It functions on the level of mitochondria, heterodimerizing with Bax, Bak, Bid and also the pro-apoptotic mitochondrial BNIP3 protein, thus preventing subsequent activation of a caspase cascade (Boyd et al., 1994; Han et al., 1998).

E1B-55 kDa protein carries out a lot of important functions during viral life cycle. First of all, in the early phase of infection, it facilitates E1A-mediated transformation, by blocking p53 activity (Yew and Berk, 1992), as well as independently of p53 inhibition (Sieber and Dobner, 2007). During the late phase, E1B-55 kDa is responsible for the transport of viral mRNAs from the nucleus and controls viral protein synthesis. It also mediates the shut-off of host mRNAs nuclear export and translation of cellular proteins, in favour of the production of adenoviral components (Babiss and Ginsberg, 1984; Babiss et al., 1985; Bridge and Ketner, 1990; Leppard and Shenk, 1989; Logan and Shenk, 1984).

p53 is targeted and inhibited by E1B-55 kDa on multiple levels. Transient transfection studies indicated that E1B-55 kDa protein directly binds to the amino-terminal domain of p53 and inhibits p53-mediated transactivation (Kao et al., 1990; Martin and Berk, 1998). However, this interaction is necessary but not sufficient for inhibition of p53. It was shown that E1B-55 $\mathrm{kDa}$ possesses general transcription repression activity for a number of cellular promoters, including p53 (Yew et al., 1994). Thus, it seems more likely that E1B-55kDa binding to p53 leads to conversion of p53 from activator of transcription to the constitutive repressor (Martin and Berk, 1999).

When expressed alone or in Ad5-transformed cells, E1B-55 kDa accumulates in perinuclear cytoplasmic bodies in the complex with p53 (Roth and Dobbelstein, 2003; Zantema et al., 1985a; Zantema et al., 1985b). Cytoplasmic relocalisation of p53 is the second mechanism of p53 inactivation by E1B-55 kDa. Finally, E1B-55 kDa, when coexpressed with E4-34 kDa (the product of E4orf6 gene) or after infection with the entire adenovirus, induces proteasomal degradation of $\mathrm{p} 53$, which requires interaction of E1B- 
55 kDa with both p53 and E4-34 kDa (Fig. 7) (Cathomen et al., 1998; Querido et al., 1997; Querido et al., 2001; Roth et al., 1998; Steegenga et al., 1998).

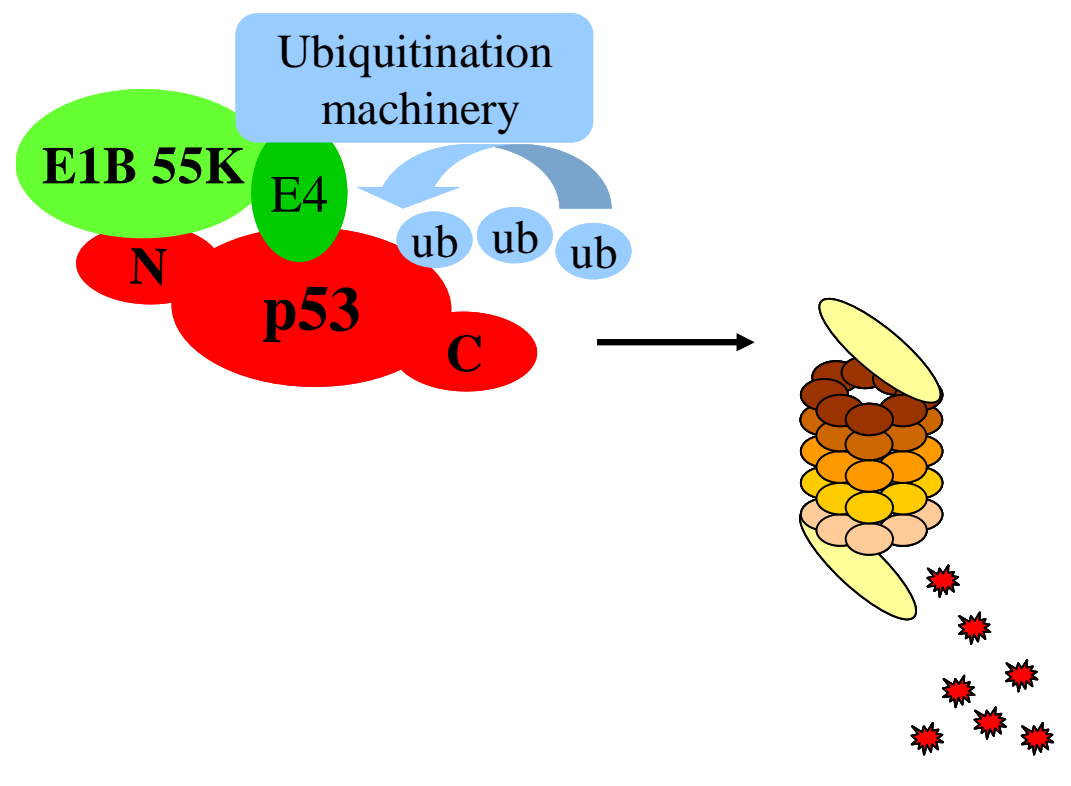

Fig. 7. Degradation of p53 by adenovirus E1B-55 KDa and E4-34 kDa proteins. E1B-55 kDa and E4-34 kDa form a triple complex with the p53 after infection. This complex recruits cellular ubiquitination machinery to the p53 and forwards it to degradation in the proteasomes.

\subsubsection{Adenovirus and cancer treatment. Oncolytic viruses. ONYX-015}

As was described before, adenovirus expresses oncogenic proteins that deregulate the function of tumour suppressors $\mathrm{pRb}$ and $\mathrm{p} 53$. The same proteins are most frequently altered in a variety of cancers. Inactivation of these signalling pathways is beneficial for virus replication, since S-phase entry is not restricted by cellular check point control. This raised the idea of engineering viruses that replicate selectively in tumor cells. Indeed, a mutant virus that is incapable to replicate in normal cells because of intact check points, but propagate and lyse cancer cells in theory represent a simple and effective solution for killing cancer cells with potentially small side effects to normal ones. One of the first oncolytic viruses created, modification of which was approved in China for treatment of head and neck cancers, was a genetically modified adenovirus named 
ONYX-015 (dl1520). This virus contains a complete deletion of E1B-55 kDa (Barker and Berk, 1987). The idea behind it was that, since E1B-55 kDa is the main inhibitor of p53 activity, E1B-55 kDa-deleted viruses should not be able to inactivate p53 and therefore should replicate selectively in cells with mutated/null p53 status, but not in cells bearing a wild type p53 gene (Bischoff et al., 1996). ONYX-015 went through numerous cell culture studies, was examined in tumor xenografts experiments in nude mice and with a moderate success in preliminary trials in patients (Heise et al., 1997; Kirn, 2001). However, the theoretical basis for this interesting approach has been disproved after some recent experiments on expanded numbers of cell lines and tumors with different p53 status. Basically, no correlation was found between p53 status and E1B-55 kDadeleted virus replication. It was shown that even in the absence of E1B-55 kDa, viruses successfully replicate in cells with wild type p53 (Goodrum and Ornelles, 1998; Rothmann et al., 1998; Turnell et al., 1999). This may be due to differential regulation of mRNA transport and protein translation (Dobner and Kzhyshkowska, 2001; Harada and Berk, 1999). In other cases, the loss of the p14ARF protein was suggested to promote replication of mutant virus in p53 wild type cells (Ries et al., 2000). Therefore, further work is required to clarify the role of p53 in adenovirus replication, in order to create an effective selective adenovirus-based anti-cancer drug.

\subsection{Aims of the study}

Our previous studies of p53 functioning after infection with E1B-55 kDa-deleted adenovirus have found that, even when E1B- $55 \mathrm{kDa}$ is not expressed, adenovirus is still able to down-regulate p53 activity. It was shown that p53 accumulates upon E1B-55 $\mathrm{kDa}$-deleted virus infection, but is functionally blocked and unable to induce expression of its target genes (Hobom and Dobbelstein, 2004; O'Shea et al., 2004).

Therefore, two important questions immediately arise from the previous observations:

1. How does adenovirus mediate the accumulation of $p 53$ ?

2. What are the mechanisms of p53 inactivation by adenovirus? 
Most of the previous results concerning p53 regulation by adenovirus were obtained from experiments with transient or stable transfection of adenoviral oncogenes. These conditions may not really reflect the physiological situation. Therefore, in this work, we use an infection system. To answer the two questions stated above, we decided to analyse a panel of E1B-55 kDa-deleted adenovirus mutants in their ability to block p53 activity. Firstly, we assesed the state of p53 after infection, i.e. posttranslational modifications of $\mathrm{p} 53$, intracellular localization, conformation, oligomerization and DNAbinding. Secondly, we asked how various E1A mutant viruses affect p53 activity. E1A was reported to regulate p53 stability in transfection studies and to bind to numerous coactivators and cofactors of p53, suggesting that E1A might indeed alter p53 modifications and activities. Finally, we searched for cellular targets that are required for p53-activity and may be modified by adenovirus infection.

Taken together, this study set out to identify the new mechanisms that adenovirus uses for inhibition of p53 activity. New findings in this field may not only lead to the construction of selectively replicating adenoviruses, but also provide insight into the mechanisms of p53 inactivation in human cancers. 


\section{Materials and Methods}

\subsection{Materials}

\subsubsection{Technical devices}

\author{
Equipment \\ Agitator, magnetic, heated \\ Bioruptor \\ Blotting-chamber, \\ semi-dry \\ Blotting-chamber, \\ wet blot \\ Centrifuge, mini \\ Centrifuge $4^{\circ} \mathrm{C}$ \\ Centrifuge $4^{\circ} \mathrm{C}$ \\ Counting chamber \\ Developing Machine
}

Electrophoresis chambers for agarose gels

Electrophoresis-System, for SDS-PAGE

Foil swelding machine

Freezer $-20^{\circ} \mathrm{C}$

Freezer $-80^{\circ} \mathrm{C}$

Heating block

Heating block (with shaking)

Ice-machine

Incubator for the cell cultures

Laminar flow cabinet

Light microscope

Liquid Nitrogen Tank

Microscope, fluorescent

Microwave-Oven

PCR machine

pH-Meter

Pipet, electric

Pipets 2.5, 20, 200, $1000 \mu \mathrm{l}$

Power supply unit

Power supply unit

Real-time PCR machine

and detection system
Name

MR 3001

UCD-200TM-EX

Minive blotter

GMC-060

5415R

Megafuge $1.0 \mathrm{R}$

Neubauer

Optimax X-Ray Film

Processor, 1170-1-000

Mini 440

Midi 450

Minive complete

Vacupack plus

Liebherr "Premium"

Product line

Hera freeze

HTB-1-131

Thermomixer comfort

B100

Hera Cell 150

Hera Safe

Axovert 40C

Lab systems LS 4800

Axiolmager.Z1

MW 17705

Thermocycler

T personal

WTW-720

Portable-XP

Eppendorf Research

Powerpack P25T

PowerPac Basic

DNA Engine (PTC-200)

Chromo4 ${ }^{\mathrm{TM}}$ Real-time

PCR Detector

\section{Company}

Heidolph

Diagenode

Harnischmacher

Labortechnik

Amersham Biosciences

LMS

Eppendorf

Heraeus Instruments

Brand

Typon Medical

Harnischmacher

Labortechnik

Amersham Biosciences

KRUPS

Liebherr

Heraeus Instruments

HLC - Haep

Labor Consult

Eppendorf

Ziegra

Heraeus Instruments

Heraeus Instruments

Zeiss

Taylor-Wharton

Zeiss

Cinex

Biometra

WTW, Weilheim, DE

Drummond

Eppendorf

Biometra

Biorad

Peltier Thermal Cycler

Bio-Rad Laboratories 


Refrigerator $4^{\circ} \mathrm{C}$
Rotator
Scales
Scales
Shaker
Shaker
Shaker
Spectrophotometer
UV-transilluminator
Vacuum pump
Vortex
Water bath

Profi Line

PTR 300

Acculab ALC-6100.1

LE623S

DRS-12

Promax 2020

Rocky

NanoDrop ND-1000

Intas UV system

Vacusafe comfort

Vortex Genie 2

TW 20
Liebherr

Grant Bio

Sartorius

Sartorius

neo Lab

Heidolph

Schütt Labortechnik

PeqLab

Intas

IBS Integra Biosciences

Scientific Industries

Julabo Labortechnik

\subsubsection{Consumable materials}

Name
4 well chamber slides, serile
6 well cell culture plates, sterile
96 well PCR duo plate, skirted
Adefodur developing-
concentrate for developing
machine
Adefodur fixer-concentrate for
developing machine
Casting trays for agarose gel
Cell scraper
Cell scraper
Centrifuge tubes
Combs for agarose gels
Coverslips
Cryo Tube Vials
Gloves, Latex
Micro tubes
Micro tubes TPX
Nitrocellulose
Protran membrane
Paster pipets, glass
Parafilm
Pipettes, sterile
Pipet tips

Sponge, Dacron
Description

Lab-Tek Permanox slide

Cellstar

for qPCR

$82 \times 70 \mathrm{~mm}$,

$82 \times 105 \mathrm{~mm}$

$16 \mathrm{~mm}$

$25 \mathrm{~mm}$

$15 \mathrm{ml}, 50 \mathrm{ml}$

$1,5 \mathrm{~mm}$ thick,

$8,13,18$ teeth

$24 \times 60 \mathrm{~mm}$

$1.8 \mathrm{ml}$

Safe Skin PFE

$0.5 \mathrm{ml}, 1.5 \mathrm{ml}, 2 \mathrm{ml}$

$1,5 \mathrm{ml}$

BA83 $(30 \mathrm{~cm} \times 3 \mathrm{~m})$

$230 \mathrm{~mm}$

$5 \mathrm{ml}, 10 \mathrm{ml}, 25 \mathrm{ml}$

with or without filter

$(20 \mu \mathrm{l}, 200 \mu \mathrm{l}, 1000 \mu \mathrm{l})$

$9 \times 10.5 \mathrm{~cm}, 6 \mathrm{~mm}(1 / 4 ")$ thick GE Healthcare

\section{Company}

Nunc

Greiner-bio-one

Sarstedt

Omnilab

Omnilab

Harnischmacher

Labortechnik

Sarstedt

Sarstedt

Sarstedt

Harnischmacher

Labortechnik

Menzel $\mathrm{GmbH}$

and Co KG

Nunc

Kimberly Clark

Sarstedt

Diagenode

Omnilab

VWR international

Pechiney

Sarstedt

Sarstedt 
Sealing tape, optically clear

Syringe

Syringe needles

Tissue culture dish, sterile

Tissue culture flask, red filter

cap, sterile

X-ray cassette

X-ray film for 96 well PCR Duo plates $1 \mathrm{ml}$

$0,6 \times 25 \mathrm{~mm}$

Cellstar, $100 \times 20 \mathrm{~mm}$

Cellstar, $75 \mathrm{~cm}^{2}, 175 \mathrm{~cm}^{2}$

ICE 60406

Fuji, RX blue, $13 \times 18 \mathrm{~cm}$
Sarstedt

BD Plastipak

BD Microlance

Greiner-bio-one

Greiner-bio-one

REGO X-Ray

$\mathrm{GmbH}$

Ernst Christiansen

$\mathrm{GmbH}$

\subsubsection{Chemicals}

Name

2-mercaptoethanol

2-propanol

$\beta$-glycerol phosphate disodium salt pentahydrate

( $\beta$-glycerophosphate)

Agarose NERO ultra quality

Ammonium persulfate (APS)

Bromphenol blue

Calcium chloride $\left(\mathrm{CaCl}_{2}\right)$

Camptothecin

Chloroform

Ciprobay 200

Cycloheximide

DAPI dilactate

Di-sodiumhydrophosphate dihydrate

$\left(\mathrm{Na}_{2} \mathrm{HPO}_{4} \times 2 \mathrm{H}_{2} \mathrm{O}\right)$

Dithiothreitol (DTT)

EDTA

Ethanol, $>99.9 \%$

Ethanol denatured, $99.8 \%$

Ethidium bromide

Fetal Calf Serum (FCS)

Formaldehyde, 37\%

Glycerol

Glycine

HEPES

Hydrochloric acid $(\mathrm{HCl})$

lodacetamide

L-glutamine

\section{Company}

Roth

Roth

Fluka

Roth

Roth

Sigma-Aldrich

Roth

Sigma-Aldrich

Roth

Bayer

Sigma-Aldrich

Sigma-Aldrich

Roth

Roth

Roth

Merck

Roth

Roth

GIBCO / Invitrogen

Roth

Roth

Roth

Roth

Roth

AppliChem

GIBCO / Invitrogen 


\begin{tabular}{|c|c|}
\hline Magnesium chloride $\left(\mathrm{MgCl}_{2}\right)$ & Roth \\
\hline Methanol & Roth \\
\hline Milk, non fat, powder & Roth \\
\hline N-ethylmaleimide & Sigma \\
\hline $\mathrm{N}, \mathrm{N}, \mathrm{N}^{\prime}, \mathrm{N}^{\prime}$-Tetramethylendiamin (TEMED) & Roth \\
\hline NP40 & USB \\
\hline Penicillin/Streptomycin & GIBCO / Invitrogen \\
\hline pH-Solution 10,01 & Roth \\
\hline pH-Solution 4,01 & Roth \\
\hline pH-Solution 7,01 & Roth \\
\hline Ponceau S & Roth \\
\hline $\begin{array}{l}\text { Rotiphorese Gel } 30 \quad(30 \% \\
\text { bisacrilamid solution; ratio } 37.5: 1)\end{array}$ & Roth \\
\hline Potassium chloride $(\mathrm{KCl})$ & Roth \\
\hline \multicolumn{2}{|l|}{ Potassium dihydrogen phosphate $\left(\mathrm{KH}_{2} \mathrm{PO}_{4}\right)$} \\
\hline Sodium acetate & Roth \\
\hline Sodium deoxycholate & AppliChem \\
\hline Sodium dodecyl sulfate (SDS) & Roth \\
\hline Sodium chloride $(\mathrm{NaCl})$ & AppliChem \\
\hline Sodium hydrogen carbonate ( $\mathrm{NaHCO} 3$ ) & Roth \\
\hline Sodium hydroxide $(\mathrm{NaOH})$ & Roth \\
\hline Tetracycline & Sigma \\
\hline Trasylol (aprotinin 500.000 KIE) & Bayer \\
\hline Trichostatin A & Sigma-Aldrich \\
\hline Tris & Roth \\
\hline Triton X-100 & AppliChem \\
\hline Trypsin-EDTA & GIBCO / Invitrogen \\
\hline
\end{tabular}

\subsubsection{Enzymes}

\section{Name}

M-MuLV Reverse Transcriptase
Catalogue number

M0253
Company

NEB 


\subsubsection{Kits and reagents}

Name

$10 \times$ Taq buffer with $\mathrm{KCl}$

$25 \mathrm{mM} \mathrm{MgCl} 2$

BSA

Chelex 100

Dulbecco's Modified Eagle's Medium

1x, powder

dNTPs, $25 \mu \mathrm{M}$ each

Fluorescent mounting medium

GlycoBlue

Immobilon western chemiluminescent

HRP substrate

$\mathrm{iQ}^{\mathrm{TM}}$ SYBR green supermix

iScript ${ }^{\mathrm{TM}} \mathrm{CDNA}$ Synthesis Kit

NEBuffer for M-MuLV reverse B0253 transcriptase

PBS tablets

Protease inhibitor cocktail tablets

Complete, EDTA free

Proteinase $\mathrm{K}$

Protein A sepharose CL-4B

RNase Inhibitor, recombinant

RQ1 RNAse-Free DNAse kit

Sepharose CL-4B (for pre-clearing)

Sonicated salmon sperm DNA

SuperSignal west femto maximum 34095

Sensitivity

Trizol

TrueBlot beads
Catalogue number Company

B38

R0971

8076.3

$142-1253$

U1420

S3023

AM9516

WBKLS0500

$170-8882$

170-8891

18912-014

11873580001

EO 0491

17-0780-01

M0307

M6101

17-0150-01

201190-81

15596-018

00-8811-25
Fermentas

Fermentas

Roth

Bio-Rad

GIBCO/

Invitrogen

Promega

DakoCytomation

Ambion

Millipore

Bio-Rad

Laboratories

Bio-Rad

Laboratories

NEB

GIBCO/

Invitrogen

Roche

Fermentas

GE Healthcare

NEB

Promega

Amersham

Bioscience

Stratagene

Pierce

Invitrogen

eBioscience 


\subsubsection{Buffers}

10x Blot Transfer Buffer (BTB)

Tris

$48 \mathrm{mM}$

Glycine

$39 \mathrm{mM}$

SDS

$0.037 \%(w / v)$

Methanol

$15 \%$

$\mathrm{pH}$ was adjusted to 8.3 with $\mathrm{HCl}$

Blocking solution

PBS

FCS

$10 \%$

\section{ChIP Buffer}

Tris-HCl pH 8.0

$50 \mathrm{mM}$

$\mathrm{NaCl}$

$150 \mathrm{mM}$

EDTA pH 8.0

$5 \mathrm{mM}$

NP40

$0.5 \%(\mathrm{v} / \mathrm{v})$

Triton X-100

$1 \%(\mathrm{v} / \mathrm{v})$

\section{ChIP++ Buffer}

ChIP buffer

NEM

$1 \mathrm{mM}$

$\beta$-glycerophosphate

$10 \mathrm{mM}$

Protease inhibitor cocktail (Roche) 


\section{ChIP Cell Collection Buffer}

Tris- $\mathrm{HCl} \mathrm{pH} 8.0$

$10 \mathrm{mM}$

$\mathrm{NaCl}$

$150 \mathrm{mM}$

EDTA pH 8.0

$1 \mathrm{mM}$

$\underline{\text { IP Buffer }}$

Tris- $\mathrm{HCl} \mathrm{pH} 8.0$

$\mathrm{NaCl}$

EDTA pH 8.0

NP40
$50 \mathrm{mM}$

$150 \mathrm{mM}$

$5 \mathrm{mM}$

$1 \%(v / v)$

Protease inhibitor cocktail (Roche) was added to the buffer freshly each time before use

$\underline{\text { Laemmli Buffer 6x }}$

Tris- $\mathrm{HCl} \mathrm{pH} 6.8$

Glycerol

SDS

DTT

Bromphenol blue

Lysis buffer

Tris-HCl pH 7.6

$\mathrm{NaCl}$

NP40
$0.35 \mathrm{mM}$

$30 \%$ (v/v)

$10 \%$ (w/v)

$9.3 \%(w / v)$

$0.012 \%(w / v)$
$50 \mathrm{mM}$

$140 \mathrm{mM}$

$0.5 \%(v / v)$ 


\section{$\underline{P B S T}$}

PBS

Tween-20

$0.1 \%(v / v)$

$\underline{P B S++}$

$\mathrm{NaCl}$

$137 \mathrm{mM}$

$\mathrm{KCl}$

$2.5 \mathrm{mM}$

$\mathrm{Na}_{2} \mathrm{HPO}_{4}$

$8 \mathrm{mM}$

$\mathrm{KH}_{2} \mathrm{PO}_{4}$

$1,47 \mathrm{mM}$

$\mathrm{MgCl}_{2}$

$0.5 \mathrm{mM}$

$\mathrm{CaCl}_{2}$

$0.9 \mathrm{mM}$

$\mathrm{pH}$ was adjusted to 7.4 with $\mathrm{HCl}$

\section{$\underline{\text { RIPA-Buffer }}$}

Tris-HCl pH 7.5

$20 \mathrm{mM}$

EDTA

$10 \mathrm{mM}$

$\mathrm{NaCl}$

$150 \mathrm{mM}$

Sodium deoxycholate

$1 \%(\mathrm{w} / \mathrm{v})$

SDS

$0.1 \%(\mathrm{w} / \mathrm{v})$

Triton-X 100

$1 \%(\mathrm{v} / \mathrm{v})$

lodacetamide

$10 \mathrm{mM}$

Trasylol

$5 \%(\mathrm{v} / \mathrm{v})$

(equals $100,000 \mathrm{KIE})$

$\mathrm{pH}$ was adjusted to 7.5 with $1 \mathrm{M} \mathrm{NaOH}$.Protease inhibitor cocktail (Roche) was added to the buffer each time before use. 
SDS Running Buffer (for SDS-PAGE)

Tris

Glycin

SDS

Stripping bufer

Tris-HCl pH 6.8

2-mercaptoethanol

SDS

$\underline{\text { Tris-Acetate (TAE) }}$

Tris

EDTA

Acetic acid

$\underline{\text { Western salts }}$

Tris

Glycine

SDS

Methanol

$\mathrm{pH}$ was adjusted to 8.3 with $\mathrm{HCl}$
$25 \mathrm{mM}$

$192 \mathrm{mM}$

$0.1 \%(w / v)$
$62.5 \mathrm{mM}$

$100 \mathrm{mM}$

$2 \%(w / v)$

$40 \mathrm{mM}$

$2 \mathrm{mM}$

$40 \mathrm{mM}$
$25 \mathrm{mM}$

$192 \mathrm{mM}$

$0.02 \%(w / v)$

$15 \%$ 


\subsubsection{Plasmids and vectors}

name

pCDNA3

p53- $\Delta \mathrm{O} ; \Delta 327-347$ source

Invitrogen

(Atz et al., 2000)

\subsubsection{Oligonucleotides}

\section{PCR}

name

p53 for

p53 rev

p21 for

p21 rev

$\mathrm{mdm} 2$ for

$\mathrm{mdm} 2 \mathrm{rev}$

puma for

puma rev

intron 1 of the p21 gene for

intron 1 of the p21 gene rev

GAPDH for

GAPDH rev

mt-RNR2 for

mt-RNR2 rev sequence

TGTGGAATCAACCCACAGCTGCAC

CTTGCCGTCCCAAGCAATGGATGA

TAGGCGGTTGAATGAGAGG

AAGTGGGGAGGAGGAAGTAG

TCAGGATTCAGTTTCAGATCAG

CATTTCCAATAGTCAGCTAAGG

GCCAGATTTGTGAGACAAGAGG

CAGGCACCTAATTGGGCTC

AAAATCCAGTTGCTGCCAAG

CACCTACCTGCCTGCTCTG

TGAAGGTCGGAGTCAACGGATTTGGT

GCAGAGATGATGACCCTTTTGGCTC

CATAAGCCTGCGTCAGATCA

CCTGTGTTGGGTTGACAGTG

\section{ChIP}

name

p21 -2283 (p53 binding site) for

p21 -2283 (p53 binding site) rev

p21 +1 (transcription start site) for p21 +1 (transcription start site) rev p21 proximal site for p21 proximal site rev

sequence

AGCAGGCTGTGGCTCTGATT

CCAGCCTCTTCTATGCCAGA

GGGGCGGTTGTATATCAGG

GGCTCCACAAGGAACTGACT

TTCTGGCCTCAAGATGCTTT

AAAACGATGCACCTCTCTGC 


\subsubsection{Antibodies}

Primary antibodies

\begin{tabular}{|c|c|c|c|c|}
\hline name & dilution & application & source & manufacturer \\
\hline Anti-p53 D01 & $1: 1000$ & WB, ChIP, IP & mouse monoclonal & $\begin{array}{l}\text { Santa Cruz } \\
\text { Biotechnology }\end{array}$ \\
\hline $\begin{array}{l}\text { Anti-p53 D01 } \\
\text { HPR-conjugated }\end{array}$ & $1: 5000$ & WB & mouse monoclonal & $\begin{array}{l}\text { Santa Cruz } \\
\text { Biotechnology }\end{array}$ \\
\hline Anti-p53 1801 & 1:1000 & WB & mouse monoclonal & $\begin{array}{l}\text { Santa Cruz } \\
\text { Biotechnology }\end{array}$ \\
\hline Anti-p53 FL-393 & $1: 200$ & IF & rabbit polyclonal & $\begin{array}{l}\text { Santa Cruz } \\
\text { Biotechnology }\end{array}$ \\
\hline Anti-p53 (pSer15) & 1:1000 & WB & mouse monoclonal & Cell Signaling \\
\hline Anti-p53 (pSer46) & 1:1000 & WB & rabbit polyclonal & Cell Signaling \\
\hline Anti-p53 (acLys382) & 1:1000 & WB & rabbit polyclona & Cell Signaling \\
\hline Anti-p53 (1620) & & IP & mouse monoclonal & Calbiochem \\
\hline Anti-p53 (240) & & IP & mouse monoclonal & Calbiochem \\
\hline Anti-p21 & $1: 500$ & WB & mouse monoclonal & Calbiochem \\
\hline Anti-Mdm2 2A10 & $1: 500$ & WB & mouse monoclonal & $\begin{array}{l}\text { Hybridoma } \\
\text { supernatant }\end{array}$ \\
\hline $\begin{array}{l}\text { Anti-Sp1 } \\
\text { Anti-RNA pol II }\end{array}$ & 1:1000 & $\begin{array}{l}\text { WB, ChIP } \\
\text { ChIP }\end{array}$ & $\begin{array}{l}\text { rabbit polyclonal } \\
\text { rabbit polyclonal }\end{array}$ & $\begin{array}{l}\text { Upstate } \\
\text { Santa Cruz }\end{array}$ \\
\hline $\begin{array}{l}\text { Anti-acetyl-histone } \\
\mathrm{H} 3(\mathrm{~K} 9 / 14)\end{array}$ & & ChIP & rabbit polyclonal & Upstate \\
\hline $\begin{array}{l}\text { Anti-acetyl-histone } \\
\mathrm{H} 4(\mathrm{~K} 5 / 8 / 12 / 16)\end{array}$ & & ChIP & rabbit polyclonal & Upstate \\
\hline Anti- $\beta$-actin & $1: 50000$ & WB & mouse monoclonal & Abcam \\
\hline Anti-HSC70 & $1: 25000$ & WB & mouse monoclonal & Santa Cruz \\
\hline Anti-HA & & ChIP & rabbit polyclonal & Santa Cruz \\
\hline Anti-SV40 & & IP & mouse monoclonal & Calbiochem \\
\hline Anti-E2A (B6-8) & $1: 20$ & WB & mouse monoclonal & $\begin{array}{l}\text { Hybridoma } \\
\text { supernatant }\end{array}$ \\
\hline
\end{tabular}

\section{Secondary antibodies}

name

Donkey a-mouse IgG $(\mathrm{H}+\mathrm{L})$

HPR-conjugated

Donkey a-rabbit lgG $(\mathrm{H}+\mathrm{L})$

HPR-conjugated

Alexa Fluor 488

anti-mouse (Alexa green)

Alexa Fluor 594

anti-rabbit (Alexa red)

\begin{tabular}{|c|c|c|}
\hline dilution & application & manufacturer \\
\hline $1: 20000$ & WB & $\begin{array}{l}\text { Jackson } \\
\text { ImmunoResearch }\end{array}$ \\
\hline $1: 20000$ & WB & $\begin{array}{l}\text { Jackson } \\
\text { ImmunoResearch }\end{array}$ \\
\hline 1:500 & IF & $\begin{array}{l}\text { Molecular Probes, } \\
\text { Invitrogen }\end{array}$ \\
\hline 1:500 & IF & $\begin{array}{l}\text { Molecular Probes, } \\
\text { Invitrogen }\end{array}$ \\
\hline
\end{tabular}




\subsubsection{Eukaryotic cell lines}

A549 - human non-small cell lung adenocarcinoma cells, p53 wild type H1299 - human non-small cell lung adenocarcinoma cells, p53-/-

HER911 - human embryonic retinoblasts, transformed with Ad5 E1-region

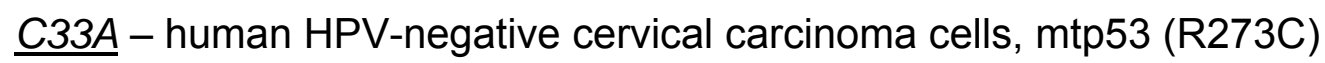

\subsubsection{Viruses}

dl309 - human Ad5 parental, pseudo-wild type virus, containing partial deletion of E3 region (Jones and Shenk, 1979)

d/338 - a derivative of dl309 virus, bearing a frame-shift deletion in E1B-55 kDa gene (Pilder et al., 1986)

$\underline{R 240 A}$ - a derivative of dl309 virus, bearing $\mathrm{R}$ to $\mathrm{A}$ point mutation at the position 240 of E1B-55 kDa (Shen et al., 2001)

$\underline{R 240 A E 1 A R 2 G}$ - a derivative of $R 240 A$ virus, carrying a substitution $R$ to $G$ at the position 2 in E1A proteins (Hobom and Dobbelstein, 2004)

E1B 2xmut - a derivative of R240A virus, carrying additional deletion of E1B-19 kDa coding region (Hobom and Dobbelstein, 2004)

dl520 - adenovirus mutant, coding E1A-12S, but not E1A-13S, lacking E1B region (does not express E1B-55 kDa and E1B-19 kDa) (Shepherd et al., 1993)

dl1101 - a derivative of dl520 virus, carrying 4-25 deletion in $\mathrm{N}$-terminal part of E1A (Shepherd et al., 1993)

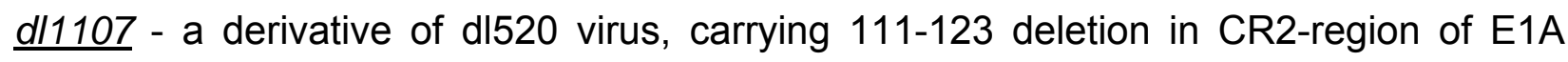
(Shepherd et al., 1993)

dl0107 - a derivative of dl520 virus, bearing 4-25 deletion in N-terminus and 111-123 deletion in CR2-region of E1A (Shepherd et al., 1993) 


\title{
3.1.12. Cell culture working solutions
}

\author{
Dulbecco's Modified Eagle Medium (DMEM-) \\ final \\ concentration \\ DMEM, $\quad 10 \mathrm{~g}$ \\ powder \\ Invitrogen \\ $\mathrm{NaHCO} 3 \quad 3.7 \mathrm{~g} / \mathrm{L}$ \\ HEPES $\quad 5.96 \mathrm{~g} / \mathrm{L}$ \\ $\mathrm{H}_{2} \mathrm{O} \quad$ up to $1 \mathrm{~L}$
}

DMEM- was filtered, and stored at $+4^{\circ} \mathrm{C}$

Dulbecco's Modified Eagle Medium with supplements (DMEM+FCS)

final

concentration

DMEM- $\quad 1 \mathrm{~L}$

FCS $\quad 10 \%$

Penicillin/Streptomycin $50 \mathrm{U} / \mathrm{mL}$

Tetracycline $\quad 2 \mu \mathrm{g} / \mathrm{mL}$

L-glutamine $\quad 200 \mu \mathrm{M}$

Ciprobay $200 \quad 10 \mu \mathrm{g} / \mathrm{mL}$

DMEM+FCS was stored at $+4^{\circ} \mathrm{C}$ and warmed up to $+37^{\circ} \mathrm{C}$ directly before use.

$\underline{\text { PBS buffer }}$

PBS for cell culture was prepared from PBS tablets (GIBCO, Invitrogen), according to manufacturer's instructions, and autoclaved. 


\subsection{Methods}

\subsubsection{Cell biology}

\section{Maintenance of cell cultures}

Adherent cells were grown in filtered culture flasks or culture dishes and maintained at $37^{\circ} \mathrm{C}$ in a humidified incubator with a $5 \% \mathrm{CO}_{2}$. All cell lines were cultivated in Dulbecco's Modified Eagle Medium (DMEM), supplemented with $10 \%$ fetal calf serum (FCS). Subcultivation was performed every 3-4 days, as soon as the cells reached $70-80 \%$ of confluence. For passaging, the medium was removed, the cells were rinsed once with the PBS buffer and incubated with $0.05 \%$ Trypsin-EDTA solution, to induce detachment from the culture dish. Trypsin was neutralized with a fresh medium, and the cells were carefully resuspended. Cells were diluted 1:8-1:10 with the fresh DMEM+FCS and passed into a new culture dish with a warm $\left(20-37^{\circ} \mathrm{C}\right)$ medium. For long term storage, the cells were frozen in liquid nitrogen. For experiments, the cell number was determined using a counting chamber (Neubauer), and the required amount of cells was seeded into corresponding culture dishes.

\section{Cells freezing procedure}

$10 \mathrm{~cm}$ culture dish or $75 \mathrm{~cm}^{2}$ culture flask with $70-80 \%$ confluent cells were used to get 1 vial of frozen cells. After trypsinization and dilution with fresh DMEM+FCS as described in chapter Maintenance of cell cultures, the cell suspension was centrifuged $5 \mathrm{~min}$ at $800 \mathrm{rpm}$. The supernatant was aspirated, the cell pellet was resuspended in $1 \mathrm{ml}$ of a cold freezing solution (10\% DMSO in FCS) and aliquoted into pre-cooled cryovials. Vials were wrapped with paper tissues, stored in $-80^{\circ} \mathrm{C}$ for 2 days and then transferred into the liquid nitrogen tank.

To recover from freezing, the vials with the cells were quickly thawed in a hand and immediately transferred into the culture dish with a warm $\left(20-37^{\circ} \mathrm{C}\right)$ medium. After one day of incubation at $37^{\circ} \mathrm{C}$, the medium was changed to the fresh one. 


\subsubsection{Virology}

\section{Preparation of high titer viral stocks}

Viruses were grown in H1299 or HER911 cells. Cells were seeded into a $175 \mathrm{~cm}^{2}$ culture flask and grown till $70-80 \%$ confluent. Cells were infected with $10 \mu \mathrm{l}$ of virus suspension in a small amount of DMEM-. Flasks were gently shaken for 3 hours in the incubator $\left(37^{\circ} \mathrm{C}, 5 \% \mathrm{CO}_{2}\right)$, medium was changed to DMEM+FCS. Cells were grown for 48-72 hours and observed once per day. When about $50 \%$ of cells was detached, they were scraped, transferred to a tube and centrifuged ( $5 \mathrm{~min}, 1000 \mathrm{rpm}$ ). The pellet was resuspended in $1 \mathrm{ml}$ of PBS and lysed by three cycles of freezing in liquid nitrogen, thawing at $37^{\circ} \mathrm{C}$ with shaking and vortexing. The lysed suspension was centrifuged $(1 \mathrm{~min}, 13000 \mathrm{rpm})$, and the supernatant was stored at $-80^{\circ} \mathrm{C}$. For getting a high titer viral stock five $175 \mathrm{~cm}^{2}$ culture flasks of H1299 or HER911 cells were infected.

\section{Virus titration}

A549 cells were seeded into 4-well chamber slide (50000 cells per well). Next day cells were infected with serial dilutions of virus stock (usually $10^{-4}, 10^{-5}, 10^{-6}$ and $10^{-7}$ ) in $0.4 \mathrm{ml}$ of DMEM-. Chamber slides were gently shaken for 3 hours in the incubator $\left(37^{\circ} \mathrm{C}, 5 \%\right.$ $\mathrm{CO}_{2}$ ), medium was changed to DMEM+FCS. Twenty-four hours post-infection cells were subjected to immunofluorescense (see the protocol in the 'Biochemistry and immunology methods') with B6-8 antibody against adenoviral E2A-72 kDa (single stranded DNAbinding protein, required for replication of virus). 4',6-Diamidino-2-phenylindol (DAPI) was used to visualize cell nuclei. Virus titer (the amount of infectious viral particles per $\mathrm{ml}$ ) was determined by counting the amount of E2A positive cells from DAPI-positive cells. The dilution that gave 4 to $40 \%$ E2A-positive cells was taken for titer calculation, according to the following formula:

Titer $=$ (amount of E2A positive cells/ amount of DAPI-positive cells) $\times 5000 \times$ inverted dilution. 


\section{Infection of cells with virus}

The required amount of cells was seeded into culture flask/dish, 6-well plate or chamber slide. Next day cells were infected with appropriate amount of virus, determined by $\mathrm{MOI}$ (multiplicity of infection - the number of infectious particle per cell). The amount of virus was calculated, using the following formula:

The amount of virus $(\mu \mathrm{l})=(\mathrm{MOI} \times$ number of seeded cells $\times 1000) /$ virus titer

The infection was performed in DMEM- for $3 \mathrm{~h}$ in the incubator $\left(37^{\circ} \mathrm{C}, 5 \% \mathrm{CO}_{2}\right)$ with a gentle shaking. The medium was changed to DMEM+FCS, cells were let grown till they were collected for the experiment.

\subsubsection{Molecular Biology}

\section{Total RNA isolation}

Cells, seeded in one well of 6-well plate was used for the preparation of total RNA, using the following procedure. Cells were scraped from the plate, transferred into eppendorf tube and centrifuged (5 min, $3000 \mathrm{rpm}$ ). The medium was removed and cell pellet was resupended in $1 \mathrm{ml}$ of Trizol (Invitrogen). Ten minutes later $200 \mu \mathrm{l}$ of chloroform was added. The mixture was vigorously shaken and let incubated for $3 \mathrm{~min}$ at room temperature, followed by centrifugation step $\left(4^{\circ} \mathrm{C}, 12000 \mathrm{rpm}, 15 \mathrm{~min}\right)$. Centrifugation resulted in separation of the mixture into 3 phases. The upper aqueous phase, containing RNA, was carefully transferred into a new tube, followed by addition $500 \mu \mathrm{l}$ of isopropyl alcohol, mixing and incubation for $10 \mathrm{~min}$ at room temperature. RNA was precipitated by centrifugation $\left(4^{\circ} \mathrm{C}, 12000 \mathrm{rpm}, 10 \mathrm{~min}\right)$, the pellet was washed with $75 \%$ ethanol, centrifuged (room temperature, $7500 \mathrm{rpm}, 5 \mathrm{~min}$ ), air dried for 15 minutes and resuspended in $30 \mu \mathrm{l}$ of nuclease free water.

\section{Quantification of RNA}

The RNA concentration was measured, using spectrophotometer NanoDrop (PeqLab). RNA absorbance was determined at $260 \mathrm{~nm}$. Ratios 260:230 and 260:280 were used to 
assess the purity of RNA. The ratios $260: 230$ around $1.8-2.0$ and $260: 280$ in the range of 2.0-2.2 were accepted as indication of 'pure' RNA. In case these values were appreciably lower, RNA was purified, as described in 'Purification of RNA'.

\section{Purification of RNA}

$30 \mu \mathrm{l}$ of RNA sample was mixed with $3 \mu \mathrm{l}$ of $125 \mathrm{mM}$ EDTA, $3 \mu \mathrm{l}$ of 3M sodium acetate and $50 \mu \mathrm{l}$ of $100 \%$ ethanol and let stand for $5 \mathrm{~min}$ at room temperature. Sample was centrifuged $15 \mathrm{~min}$ at $14000 \mathrm{rpm}$, supernatant was discarded and $210 \mu \mathrm{l}$ of $70 \%$ ethanol was added to the pellet. The pellet was washed and centrifuged (10 min, $14000 \mathrm{rpm}$ ). Supernatant was aspirated, the pellet was dried for $15 \mathrm{~min}$ and resuspended in $20 \mu \mathrm{l}$ of nuclease free water.

\section{DNA digestion of RNA samples}

To prevent false positive results in real-time PCR, caused by a contamination of isolated total RNA with genomic DNA, RNA probes were digested with DNAse, using RQ1 RNAse-Free DNAse kit (Promega). $1 \mu \mathrm{g}$ of RNA were mixed with $1 \mu \mathrm{l}$ of $10 \mathrm{x}$ reaction buffer, $1 \mu \mathrm{l}$ of DNAse $(1 \mathrm{u} / \mu \mathrm{l})$. Nuclease free water was added up to $10 \mu \mathrm{l}$. The sample was incubated at $37^{\circ} \mathrm{C}$ for $30 \mathrm{~min}$. One $\mu \mathrm{l}$ of STOP solution ( $25 \mathrm{mM}$ EDTA) was added to inactivate the enzyme and the probe was incubated for $10 \mathrm{~min}$ at $65^{\circ} \mathrm{C}$.Treated RNA was directly used as a template for reverse transcription.

\section{Reverse transcription}

Reverse transcription was performed, using either iScript ${ }^{\mathrm{TM}} \mathrm{CDNA}$ Synthesis Kit (Bio-Rad Laboratories) or home made Do-it-Yourself reverse transcription protocol.

\section{Reverse transcription with iScript ${ }^{\mathrm{TM}} C D N A$ Synthesis Kit}

The kit contained a modified Moloney murine leukemia virus-derived reverse transcriptase, dNTPs, RNAse inhibitor, oligo dT-primer and random-hexamer primer.

The reaction mix was prepared as indicated in the following table: 


\begin{tabular}{|l|l|}
\hline & \multicolumn{1}{|c|}{ volume/sample } \\
\hline 5x iSript Reaction mix & $4 \mu \mathrm{l}$ \\
\hline iSript Reverse Transcriptase & $1 \mu \mathrm{l}$ \\
\hline RNA & $\leq 1 \mu \mathrm{g}$ of total RNA \\
\hline Water & up to $20 \mu \mathrm{l}$ \\
\hline \hline
\end{tabular}

The complete reaction mix was incubated $5 \mathrm{~min} 25^{\circ} \mathrm{C}, 30 \mathrm{~min}$ at $42^{\circ} \mathrm{C}, 5 \mathrm{~min}$ at $85^{\circ} \mathrm{C}$ and then held at $4^{\circ} \mathrm{C}$. cDNA was stored at $-20^{\circ} \mathrm{C}$.

\section{Do-it-Yourself reverse transcription protocol}

Moloney murine leukemia virus-derived reverse transcriptase and the buffer for it (NEB), RNAse inhibitor (NEB), dNTPs (Promega), oligo $\mathrm{dT}_{23} \mathrm{VN}$ and random nonamers-primers were used in this protocol.

First, stock solutions were prepared:

- combined primer stock ( $15 \mu \mathrm{M}$ nonamers and $50 \mu \mathrm{M}$ oligo $\mathrm{dT}_{23} \mathrm{VN}$ )

- dNTP mix (2.5 mM of each dCTP, dATP, dTTP, dGTP)

Next, the following components were mixed (per one sample):

- $1 \mu \mathrm{g}$ of total RNA

- $2 \mu \mathrm{l}$ of combined primer stock

- $4 \mu \mathrm{l}$ of dNTP mix

- DEPC-treated water to $16 \mu \mathrm{l}$

The mix was heated $5 \mathrm{~min}$ at $70^{\circ} \mathrm{C}$, spun down briefly, put on ice.

The master mix was prepared from:

- $2 \mu$ l of NEBuffer for M-MuLV reverse transcriptase

- $0.25 \mu$ l of RNase Inhibitor (10 U)

- $0.125 \mu \mathrm{l}$ of M-MuLV Reverse Transcriptase (25 U)

- $1.625 \mu$ l of DEPC-treated water 
$4 \mu \mathrm{l}$ of master mix was added to $16 \mu \mathrm{l}$ of mix and incubated for 1 hour at $42^{\circ} \mathrm{C}$. Reverse transcriptase was inactivated at $95^{\circ} \mathrm{C}$ for $5 \mathrm{~min}$. cDNA was diluted with $30 \mu \mathrm{l}$ of nuclease free water and stored at $-20^{\circ} \mathrm{C}$

\section{Real-time PCR}

Real-time PCR technique was used to get semi-quantitative measurements of gene expression. To perform the qPCR reaction $\mathrm{iQ}^{\mathrm{TM}}$ SYBR Green Supermix, containing hotstart Taq polymerase (Bio-Rad), was used. The master mix was prepared for required amount of samples according to the table bellow:

\begin{tabular}{|l|l|l|}
\hline \multirow{2}{*}{} & for 1 sample \\
\cline { 2 - 3 } & final concentration & volume, $\mu \mathrm{l}$ \\
\hline $2 \mathrm{x}$ Supermix & $1 \mathrm{x}$ & 12.5 \\
\hline Water & & 10 \\
\hline Primer forward $(10 \mu \mathrm{l})$ & $303 \mathrm{nM}$ & 0.75 \\
\hline Primer reverse $(10 \mu \mathrm{l})$ & $303 \mathrm{nM}$ & 0.75 \\
\hline Total & & 24 \\
\hline
\end{tabular}

The master mix was aliquoted into the 96 well qPCR plate $(24 \mu \mathrm{l}$ per well) and $1 \mu \mathrm{l}$ of cDNA or $2 \mu \mathrm{l}$ of sheared DNA from ChIP procedure was added per every sample. The plate was sealed, centrifuged and incubated with a temperature conditions, described below, in the real-time PCR machine.

\begin{tabular}{|l|l|l|l|}
\hline Degree & Time & Comments & Cycles \\
\hline $95^{\circ} \mathrm{C}$ & $3 \mathrm{~min}$ & $\begin{array}{l}\text { iTaq DNA } \\
\text { Polymerase } \\
\text { Activation }\end{array}$ & 1 \\
\hline $95^{\circ} \mathrm{C}$ & $15 \mathrm{sec}$ & DNA melting & 45 \\
\hline $60^{\circ} \mathrm{C}$ & $1 \mathrm{~min}$ & $\begin{array}{l}\text { Primers } \\
\text { annealing and } \\
\text { extension }\end{array}$ & \\
\hline & & Melting curve & 1 \\
\hline
\end{tabular}


The standard curve method was used for the relative quantification of gene expression after qPCR. Calibration curves were prepared from the serial dilutions of the sample $(1: 4,1: 16,1: 64,1: 256)$, containing high cDNA amounts of gene of interest.

The relative quantities of amplified cDNA were obtained for samples and reference genes. The final values represented sample value, divided to the value of reference gene.

\subsubsection{Biochemistry and immunological methods}

\section{Immunoblot analysis}

\section{Cell harvesting and lysis}

Adherent cells were scraped in the growth medium from the 6 well plate, transferred to an eppendorf tubes and centrifuged (5 min, $1000 \mathrm{rpm}$ ). The cell pellet was lysed on ice in $100 \mu \mathrm{l}$ of RIPA buffer (cells from one well of 6 well plate). Twenty-five $\mu$ l of $6 x$ Laemmli buffer was added and samples were incubated for $5 \mathrm{~min}$ at $96^{\circ} \mathrm{C}$ for protein denaturation. Samples were vigorously shaken for $15 \mathrm{~min}$ to decrease the viscosity of DNA, centrifuged (10 min, $13000 \mathrm{rpm}$ ) and used for SDS-PAGE or kept in $-20^{\circ} \mathrm{C}$

\section{SDS-PAGE electrophoresis}

SDS-PAGE analysis is a method of separation of proteins in a polyacrilamide gel according to their electrophoretic mobility. Cell lysates, obtained by harvesting cells with RIPA buffer, as described in chapter Cell harvesting and lysis, contained denaturated proteins that possessed similar charge to mass ratios (due to SDS-binding) and were therefore resolved by size during electroforesis in SDS-PAGE.

For this, stacking and resolving polyacrylamid gels were prepared. Stacking (upper) gel contained small percentage of acrylamide $(5 \%)$ and was required for concentration of protein samples on the border of stacking and resolving gels. Resolving (lower) gel served for protein separation and the percentage of acrylamide in it was dependent on 
the molecular weight of the protein of interest. In this work $7.5 \%, 10 \%, 12 \%$ and $15 \%$ gels were used.

Gels were prepared as described in the following tables:

\begin{tabular}{|l|l|l|l|l|}
\hline Resolving gel & $7.5 \%$ & $10 \%$ & $12 \%$ & $15 \%$ \\
\hline Water & $4.8 \mathrm{ml}$ & $4.0 \mathrm{ml}$ & $3.3 \mathrm{ml}$ & $2.3 \mathrm{ml}$ \\
\hline $\begin{array}{l}30 \% \text { Acrylamide- } \\
\text { solution }\end{array}$ & $2.5 \mathrm{ml}$ & $3.3 \mathrm{ml}$ & $4.0 \mathrm{ml}$ & $5.0 \mathrm{ml}$ \\
\hline $\begin{array}{l}1.5 \mathrm{M} \text { Tris-HCl buffer } \\
\mathrm{pH} 8.8\end{array}$ & $2.5 \mathrm{ml}$ & $2.5 \mathrm{ml}$ & $2.5 \mathrm{ml}$ & $2.5 \mathrm{ml}$ \\
\hline $10 \%$ SDS in water & $100 \mu \mathrm{l}$ & $100 \mu \mathrm{l}$ & $100 \mu \mathrm{l}$ & $100 \mu \mathrm{l}$ \\
\hline $10 \%$ APS in water & $100 \mu \mathrm{l}$ & $100 \mu \mathrm{l}$ & $100 \mu \mathrm{l}$ & $100 \mu \mathrm{l}$ \\
\hline TEMED & $4 \mu \mathrm{l}$ & $4 \mu \mathrm{l}$ & $4 \mu \mathrm{l}$ & $4 \mu \mathrm{l}$ \\
\hline
\end{tabular}

\begin{tabular}{|l|l|}
\hline Stacking gel & $5 \%$ \\
\hline Water & $1.4 \mathrm{ml}$ \\
\hline $\begin{array}{l}30 \% \text { Acrylamide- } \\
\text { solution }\end{array}$ & $0.33 \mathrm{ml}$ \\
\hline $\begin{array}{l}1 \mathrm{M} \text { Tris-HCl buffer } \\
\mathrm{pH} 6.8\end{array}$ & $0.25 \mathrm{ml}$ \\
\hline $10 \%$ SDS in water & $20 \mu \mathrm{l}$ \\
\hline $10 \%$ APS in water & $20 \mu \mathrm{l}$ \\
\hline TEMED & $2 \mu \mathrm{l}$ \\
\hline
\end{tabular}

After gel polymerization, 10 to $20 \mu \mathrm{l}$ of cell lysate were loaded into the pockets of stacking gel. Electrophoresis was performed at $15 \mathrm{~mA}$ (per one gel) for a stacking gel and $20 \mathrm{~mA}$ (per one gel) for a resolving gel. 


\section{Western blot}

After separation in the SDS-PAGE proteins were transferred onto a nitrocellulose membrane by western blot technique. Semidry blot and wet blot were used, depending on needs. Semi-dry blot was conducted in BTB buffer for $50 \mathrm{~min}$ at $17 \mathrm{~V}$. Wet blot was performed in Western Salts buffer for 2,5-4 hours at $25 \mathrm{~V}$. The quality of gel loading and transfer was estimated after the staining of membranes with Ponceau $S$ solution.

\section{Immunostaining}

For protein visualization after western blot, membranes were subjected to immunostaining. First, membranes were blocked with a $5 \%$ non-fat milk solution in PBST (called 'milk') for 30 min followed by incubation with primary antibody, diluted in milk for 2 hours or overnight $\left(4^{\circ} \mathrm{C}\right)$. Subsequently, membranes were washed 3 times for 10 min in PBST and incubated with secondary HPR-conjugated antibody for one hour. Washing with PBST was repeated the same way as after the first antibody incubation. All washing and incubation steps were fulfilled with gentle shaking at room temperature, if not specified otherwise. For protein detection membranes were incubated in 1:1 solution of enhanced chemiluminescence (ECL) system (Immobilon Western Chemiluminescent HRP substrate or Super Signal West Femto, depending on strength of the signal), sealed in a transparent foil and exposed to X-ray film in X-ray cassette for $1 \mathrm{sec}-30 \mathrm{~min}$. X-ray films were developed and fixed, using Optimax X-Ray Film Processor.

\section{Stripping procedure}

In order to reuse the membranes after immunoblot they were subjected to stripping procedure that removes the antibodies from their surface. Membranes were incubated in stripping buffer at $60^{\circ} \mathrm{C}$ for 45 min with shaking, followed by washing with PBST ( 3 times for $10 \mathrm{~min}$ ). From this point membranes were ready for a new immunostaining.

\section{Immunoprecipitation}

For immunoprecipitation cells were seeded into $75 \mathrm{~cm}^{2}$ tissue culture flasks $\left(2 \times 10^{6}\right.$ cells in each). One flask was used for 4 immunoprecipitations. Cells were scraped, centrifuged (5 min, $3000 \mathrm{rpm}$ ), the pellet was resuspended in $800 \mu \mathrm{l}$ of IP buffer and 
passed 5-10 times through a syringe. The suspension was centrifuged for $10 \min \left(4^{\circ} \mathrm{C}\right.$, $13000 \mathrm{rpm}$ ) to get rid of cell debris, and the supernatant was transferred into a new eppendorf tube. The lysate was precleared with $70 \mu$ of TrueBlot anti-mouse IgG beads (eBioscience) for $30 \mathrm{~min}$ with rotation at $4^{\circ} \mathrm{C}$. The beads were then briefly spun down ( 1 min, $13000 \mathrm{rpm}, 4^{\circ} \mathrm{C}$ ) and the supernatant was transferred into a new tube. Fifty $\mu$ l of the lysate was taken as 'input', treated with $10 \mu$ l of RIPA buffer, boiled for 5 min and stored at $-20^{\circ} \mathrm{C}$. The rest was divided into 4 parts and $1 \mu \mathrm{g}$ of corresponding antibody were added to each part. Samples were diluted with IP buffer to $500 \mu \mathrm{l}$ and were rotated for 1 hour at $4^{\circ} \mathrm{C}$. Fifty $\mu \mathrm{l}$ of TrueBlot anti-mouse IgG beads (eBioscience) were added per each sample and the beads continued rotation for one more hour at $4^{\circ} \mathrm{C}$. After precipitation tubes were centrifuged $\left(2 \mathrm{~min}, 10000 \mathrm{rpm}, 4^{\circ} \mathrm{C}\right)$ and supernatant was discarded. The beads were washed with $500 \mu$ of IP buffer by vigorous shaking for 3 min at $4^{\circ} \mathrm{C}$, spinning down $\left(1 \mathrm{~min}, 6000 \mathrm{rpm}, 4^{\circ} \mathrm{C}\right)$ and aspirating the supernatant. Finally, the beads were resuspended in $70 \mu$ l of Laemmli buffer $2 x$ (prepared from Laemmli buffer $6 \mathrm{x}$, by dilution with water), vortexed and boiled for 5 min for protein denaturation. After centrifugation ( $3 \mathrm{~min}, 10000 \mathrm{rpm}$ ) $35 \mu \mathrm{l}$ of supernatant and the whole input sample were loaded on the SDS-PAGE, followed by western blot and immunostaining, as described in chapter Immunoblot analysis.

\section{Chromatin immunoprecipitation}

\section{Day 1}

Cells were seeded in $75 \mathrm{~cm}^{2}$ culture flasks or $10 \mathrm{~cm}$ culture dishes $\left(1 \times 10^{6}\right.$ cells in each).

\section{Day 2}

Cells were infected or treated with camptothecin.

\section{$\underline{\text { Day } 3}$}

Twenty-four hours later protein-DNA crosslinking was performed with $1 \%(\mathrm{v} / \mathrm{v})$ formaldenyde in PBS for 15 min, stopped by treatment with $0.125 \mathrm{M}$ glycine solution in PBS for 5 min. After washing with PBS, cells were scraped in ChIP cell collection buffer 
and centrifuged $1000 \mathrm{rpm}$ for $5 \mathrm{~min}$. Pellets were washed once with $1 \mathrm{ml}$ of ChIP++ buffer and resuspended in $300 \mu \mathrm{l}$ of ChIP++ buffer. The lysates were transferred into the TPX tubes and sonicated in water bath sonicator (Bioruptor) to shear the chromatin to a length between 500 - 1000 b.p. Samples were sonicated 25 cycles with two ice-fresh water changes in between, using the following settings: power $\mathrm{H}, 1$ cycle $-30 \mathrm{sec}$ on, $30 \mathrm{sec}$ off. The lysates were cleared by centrifugation at $12000 \mathrm{rpm}, 10 \mathrm{~min}$, at $4^{\circ} \mathrm{C}$, and supernatants were transferred to new tubes. The sepharose for pre-clearing was washed 3 times with ChIP buffer. After final wash ChIP buffer was added to the beads to achieve $50 \%$ slurry. One-hundred $\mu \mathrm{l}$ of sepharose suspension was added to the sheared chromatin and samples were placed on the rotator at $4^{\circ} \mathrm{C}$ for 1 hour for pre-clearing. Samples were centrifuged at $12000 \mathrm{rpm}, 10 \mathrm{~min}$, at $4^{\circ} \mathrm{C}$, and supernatants were transferred to new tubes. The pre-cleared chromatin was diluted with $\mathrm{ChIP++}$ buffer according to the number of immunoprecipitations at a rate of $100 \mu \mathrm{l}$ of lysate per precipitation and $100 \mu \mathrm{l}$ for input. One or two $\mu \mathrm{g}$ of antibody per $100 \mu \mathrm{l}$ of lysate was added, samples were further diluted with ChIP++ buffer up to $500 \mu \mathrm{l}$ and incubated overnight at $4^{\circ} \mathrm{C}$ with rotation. The input samples $(100 \mu \mathrm{l})$ were mixed with $2 \mu \mathrm{l}$ of glycogen (Glycoblue), vortexed, resuspended in $200 \mu \mathrm{ll}$ of $100 \%$ ethanol and placed for $20^{\circ} \mathrm{C}$ overnight.

Protein A sepharose (GE Healthcare) was blocked with BSA and sheared salmon sperm DNA to avoid unspecific precipitation. For this, small amount of protein $A$ sepharose powder $(0.5-1 \mathrm{ml}$ ) was put into a $15 \mathrm{ml}$ tube, followed by $0.5 \mathrm{~g}$ of BSA and $100 \mu \mathrm{l}$ of sonicated salmon sperm DNA. The tube was filled with ChIP buffer and swelled overnight at $4^{\circ} \mathrm{C}$ with rotation.

\section{Day 4}

Blocked protein A sepharose was washed three times with ChIP buffer (centrifuged at $2000 \mathrm{rpm}, 2 \mathrm{~min}, 4^{\circ} \mathrm{C}$ ) and filled with ChIP++ buffer in the end to get $50 \%$ sepharose slurry. Thirty $\mu \mathrm{l}$ of this slurry was added to each immunoprecipitation and samples were incubated for 2 hours at $4^{\circ} \mathrm{C}$ with rotation. During this time input probes were centrifuged 
(13000 rpm, $20 \mathrm{~min}, 4^{\circ} \mathrm{C}$ ), and DNA pellets were washed once with $500 \mu \mathrm{l}$ of $70 \%$ ethanol and air-dried for $15 \mathrm{~min}$.

After 2 hours of incubation the immune-sepharose complexes were washed 6 times with $1 \mathrm{ml}$ of cold ChIP buffer, centrifuged for $2 \mathrm{~min}$ at $2000 \mathrm{rpm}$ and $4^{\circ} \mathrm{C}$, and supernatant was removed. After last step supernatant was removed very carefully, without touching the beads. One-hundred $\mu \mathrm{l}$ of $10 \%(\mathrm{w} / \mathrm{v})$ Chelex 100 slurry was added to the washed beads and to the input DNA pellet. After brief vortexing, samples were heated at $95^{\circ} \mathrm{C}$ for $10 \mathrm{~min}$, followed by cooling and addition of $1-2 \mu \mathrm{l}$ of $20 \mu \mathrm{g} / \mu \mathrm{l}$ Proteinase $\mathrm{K}$ to each sample. Tubes were vortexed and incubated at $55^{\circ} \mathrm{C}$ for 30 min with shaking at 1000 $\mathrm{rpm}$. Proteinase $\mathrm{K}$ was inactivated by heating $\left(95^{\circ} \mathrm{C}, 10 \mathrm{~min}\right)$, samples were centrifuged (12000 rpm, $1 \mathrm{~min}, 4^{\circ} \mathrm{C}$ ), supernatants were carefully transferred into new tubes, and 2 $\mu$ was used for $\mathrm{qPCR}$.

\section{Immunofluorescence}

Prior to immunofluorescence, the cells were grown in chamber slides. At the day of the experiment, the medium was removed, the cells were washed with PBS++ and fixed in $4 \%$ solution of formaldehyde in PBS++ for 20 min. After fixation, the cells were washed twice with PBS++ and permealized with $0.2 \%$ of Triton X-100, diluted in PBS++, for 25 $\min$.

Cells were thoroughly washed with PBS ++4 times and incubated in blocking solution for $10 \mathrm{~min}$. First antibodies were diluted in blocking solution and added to the slides for 1 hour, followed by a washing step (3 times, PBS++). Thereafter slides were incubated with secondary antibodies (diluted in blocking solution), conjugated to different fluorochromes, for $40 \mathrm{~min}$ in the dark. After the second washing ( 3 times, PBS++) slides were incubated with $0.1 \mu \mathrm{g} / \mathrm{ml}$ DAPI-solution in PBS++ for $5 \mathrm{~min}$ and mounted. The fluorescent pictures were taken, using the fluorescent microscope Axioiscope (Zeiss)

\section{Oligomerization studies}

Cells were grown in 6 well plates. At the day of experiment they were scraped off from the plate, transferred into $1.5 \mathrm{ml}$ tubes and centrifuged (3000 rpm, $5 \mathrm{~min}$ ). Supernatants 
were aspirated, the cells were washed once with PBS and spun again (3000 rpm, 5 min). The pellets were lysed in $100 \mu \mathrm{l}$ of Lysis buffer for $20 \mathrm{~min}$ on ice. After the centrifugation step $\left(13000 \mathrm{rpm}, 30 \mathrm{~min}, 4^{\circ} \mathrm{C}\right)$ the supernatants were transferred to the new tubes and glutaraldehyde $(0,0025 \%$ and $0,01 \%$ aqueous solution) was applied for $15 \mathrm{~min}$. Twenty $\mu$ l of $6 \mathrm{x}$ Laemmli buffer was added, samples were boiled for $10 \mathrm{~min}$ and subjected to SDS-PAGE and immunoblotting as described in chapter Immunoblot analysis. 


\section{Results}

\subsection{Mechanisms of p53 accumulation after infection with E1B-55 kDa-deleted viruses}

\subsection{1. p53 levels and activity in A549 cells after infection with E1B-55 kDa deletion mutants}

In order to assess the influence of adenovirus infection on p53 levels and activity, A549 cells (wt p53) were infected with adenoviruses bearing a E1B-55 kDa deletion (dl338, an analogue of the ONYX-015 virus) or a point mutation of E1B-55 kDa (R240A) that disrupts the p53-E1B-55 kDa interaction. Wild type adenovirus (dl309) was used as a control. A549 cells were infected at a MOI (multiplicity of infection) of 20 for $24 \mathrm{~h}$ and then subjected to immunoblot analysis. As shown in Fig. 8A, p53 accumulated to high amounts after dl338 and R240A infection, but not when using wild type virus, in agreement with the essential role of E1B-55 kDa in p53 degradation. However, despite the presence of high amounts of p53, the levels of p53 target gene products p21 and Mdm2 were found down-regulated after infection, when quantifying corresponding proteins and mRNAs (Fig. 8, A and B). Hence, infection with E1B-55 kDa-deficient infection leads to the accumulation of a transcriptionally inactive form of p53 protein.

\subsection{2. p53 protein stability after infection with E1B-55 kDa deletion mutants}

To understand the mechanisms of p53 accumulation, we performed real time PCR analysis of p53 mRNA, isolated from dl338 and R240A-infected cells. As shown in Fig. $9 \mathrm{~A}$, the viruses under study did not change the mRNA levels of p53 to an extent comparable with the protein levels (Fig. 8A). Instead, treating the cells with an inhibitor 
A

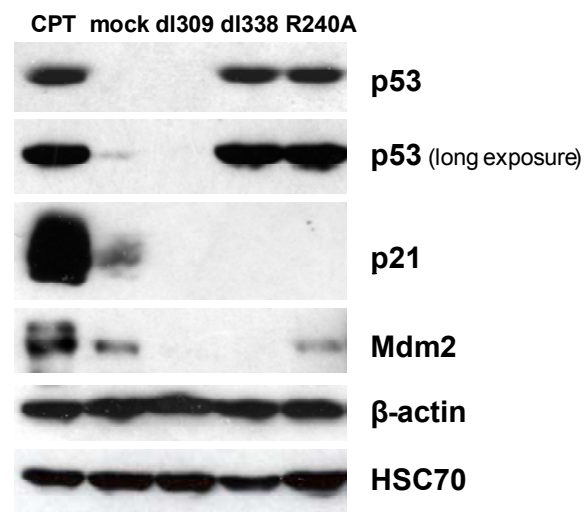

B

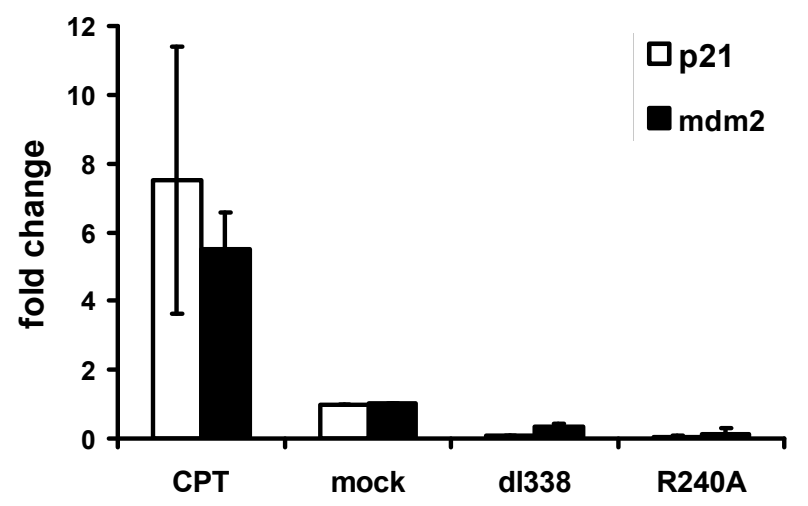

Fig. 8. Accumulation of inactive p53 after infection with E1B-55 kDa mutant adenoviruses. A549 cells were mock-infected, infected with wild type adenovirus (dl309) or with adenovirus mutants dl338 (lacking E1B-55 kDa) and R240A (carrying a substitution R to A at position 240 of E1B-55 kDa, resulting in strongly reduced p53 binding) at a multiplicity of infection (MOI) of 20. For a positive control, cells were treated with the DNA-damaging topoisomerase inhibitor camptothecin (CPT, 300nM). Twenty-four hours after infection the cells were harvested. A, p53, p21, and Mdm2 proteins were detected by immunoblot analysis with the corresponding antibodies (for p53 - D01 antibody) B, Total RNA was isolated, reverse transcribed and subjected to real-time PCR analysis with primers amplifying p21 and Mdm2 cDNA. Results were normalized to GAPDH mRNA. Mean values from three independent experiments are shown with standard deviations.

of translation, cycloheximide, indicated the stabilization of the p53 protein upon infection with E1B-55 kDa-deficient viruses (Fig. 9B).

\subsection{3. p53 protein stability after infection with E1A-deletion mutants}

Adenovirus E1A proteins were shown previously to increase p53 levels by blocking proteasomal activity (Zhang et al., 2004). These results were obtained by transient transfection of cells with E1A gene constructs, bearing deletions near the $\mathrm{N}$-terminus $(\Delta 4-25)$ and in the CR2 region $(\Delta 111-123)$ of E1A gene. These mutants code for E1A proteins that no longer bind to proteasome subunits Sug1 (S8) or S2 and thus allow p53 degradation in proteasomes according to previous analyses. We now assessed the ability of these mutants to degrade p53 in infected cells. A549 cells were infected 
with adenovirus mutants dl1101 and dl0107 that do not bind Sug1 (S8) and S2, respectively (Turnell et al., 2000; Zhang et al., 2004). Immunoblot analysis with an antibody to p53 revealed, however, that these two mutants still allow p53 accumulation, albeit with lower efficiency (Fig. 10). We conclude that proteasome inhibition by E1A contributes only partially, if at all, to the accumulation of p53.

A

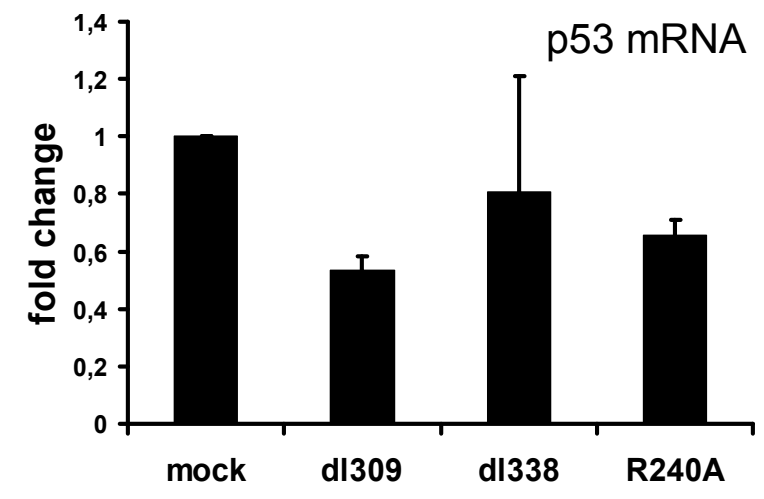

B

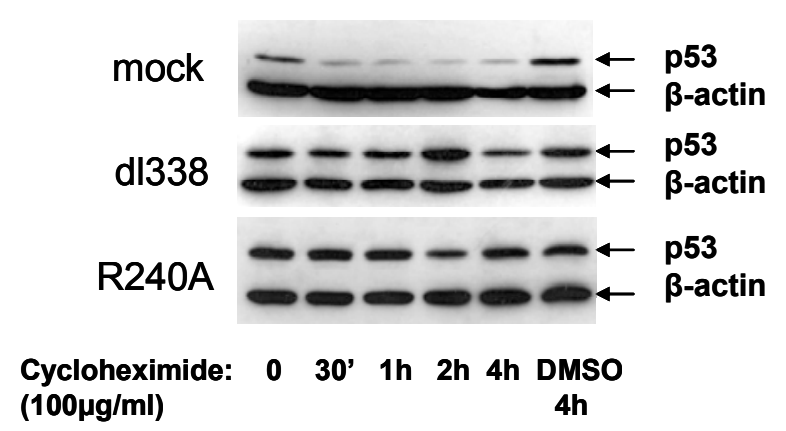

Fig. 9. Stabilization of p53 protein after adenovirus infection. A549 cells were mockinfected, infected with wild type adenovirus (dl309) or with adenovirus mutants dl338 (lacking E1B-55 kDa) and R240A (carrying a substitution R to A at position 240 of E1B-55 kDa, resulting in strongly reduced p53 binding) at a $\mathrm{MOI}$ of 20 . A, Twenty-four hours after infection, the cells were harvested, total RNA was isolated, reverse transcribed and subjected to real-time PCR analysis with primers amplifying p53 cDNA. Results were normalized to GAPDH mRNA. Mean values from three independent experiments are shown with standard deviations. B, Twenty-four hours after infection, the cells were treated with the inhibitor of translation cycloheximide for the indicated durations, or with the DMSO solvent alone for 4 hours. p53 levels were determined by immunoblot analysis with D01 antibody. Note that a longer exposure was used in the case of mock-infected cells. 


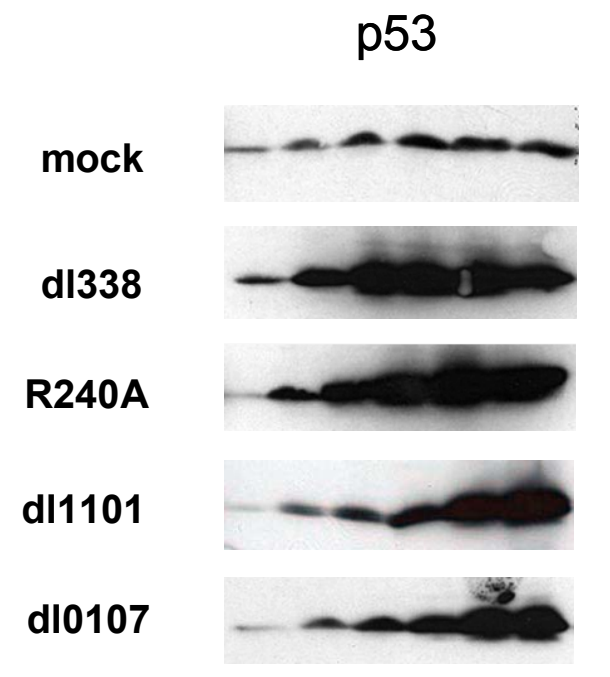

$\begin{array}{lllllll}4 & 12 & 18 & 24 & 36 & 48 & \text { hours }\end{array}$

Fig. 10. p53 accumulates after infection with E1A-deletion mutants incapable to block proteasome. A549 cells were mock-infected, infected with E1B-55 kDa adenovirus mutants dl338 and R240A or E1A-deletion mutants dl1101 and dl0107, described in Materials and Methods at a $\mathrm{MOI}$ of 50 . At the indicated time points post infection, the cells were harvested and subjected to immunoblotting using p53 D01 antibody.

\subsection{Mechanisms of $\mathrm{p} 53$ inactivation after adenovirus infection with E1B-55 kDa-deleted viruses}

\subsubsection{State of p53 in the infected cells}

Stress signalling and DNA-damage increase the half-life of the p53 protein as well as its transcriptional activity. Accumulation of p53 is required but not sufficient for p53 activation. It is generally accepted that to become transcriptionally active, p53 must possess proper oligomerization and conformation, acquire multiple posttranslational modifications, localize in the nucleus and bind its DNA target elements. Experiments, described in this chapter, were conducted to check, whether adenovirus may interfere with any of these properties of p53 in order to block its activity. 


\section{Intracellular localization}

To address whether E1B-55 kDa-mutant viruses are inactivating p53 by dislocalization, we detected p53 by immunofluorescence after infection. As documented in Fig. 11, p53 is found in the nucleus upon infection with dl338 and R240A, whereas wild type adenovirus dl309 did not accumulate p53, as expected. Nuclear staining of p53 after infection was evenly distributed and did not merge with viral replication centres, as detected by antibodies to the E2A DNA binding protein. Thus, the lack of p53 activity can not be attributed to improper localization in infected cells.
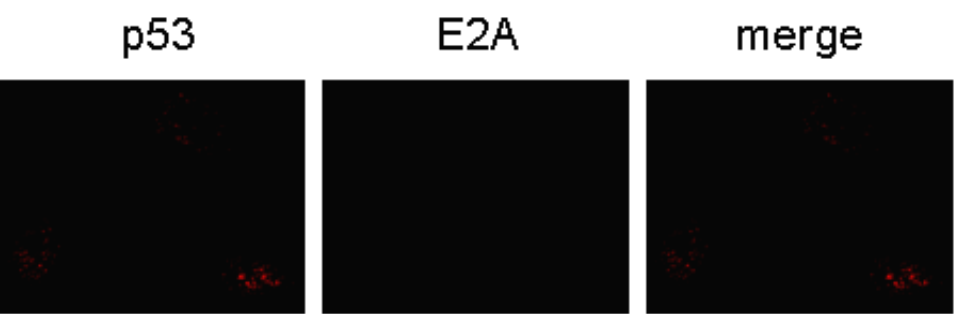

DAPI
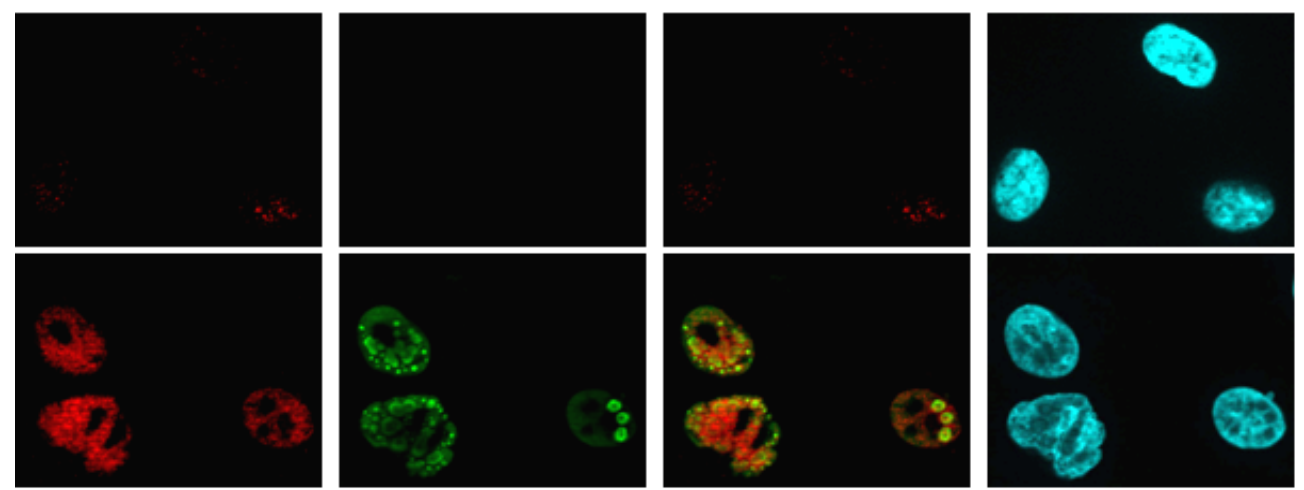

mock
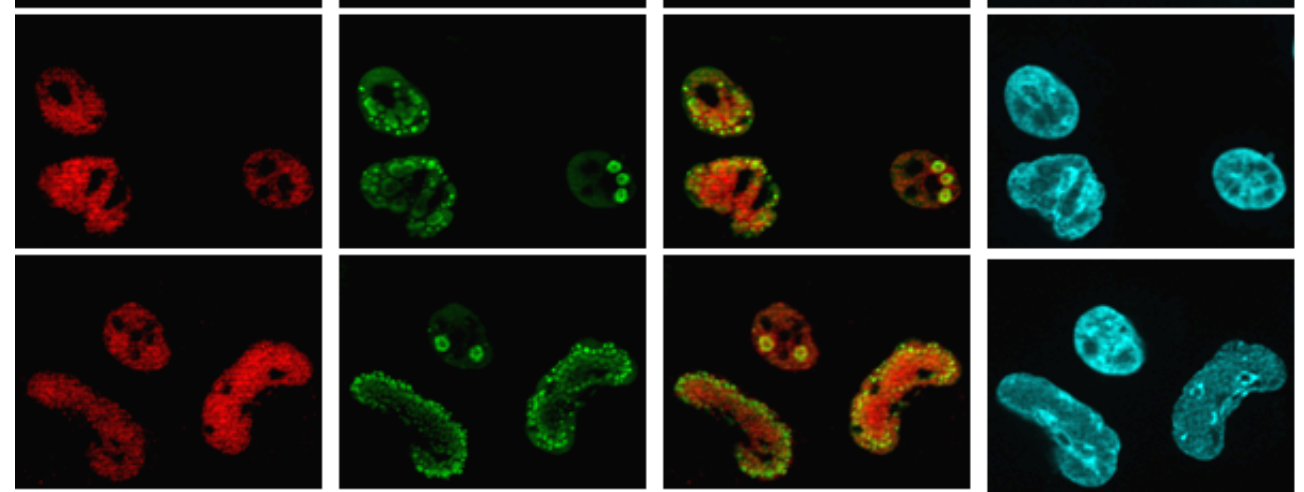

d/338
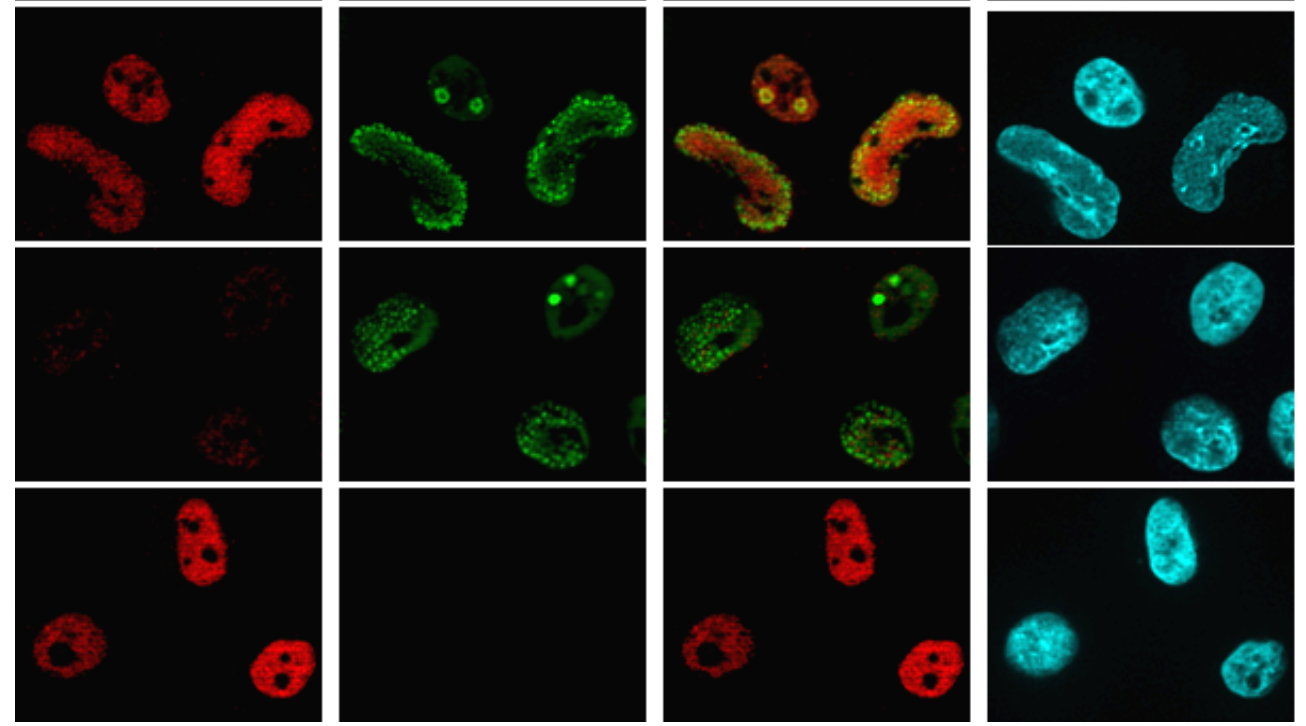

\section{$\mathrm{R} 240 \mathrm{~A}$}

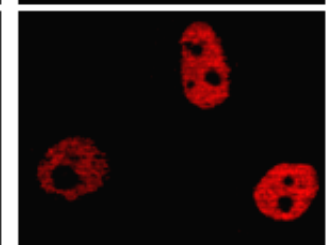

camptothecin

Fig. 11. p53 accumulates in the nuclei of A549-cells, infected with E1B-55 kDa-deleted viruses. A549 cells were mock-infected, infected with the indicated adenovirus mutants at a $\mathrm{MOI}$ of 5 or treated with DNA-damaging drug camptothecin $(300 \mathrm{nM})$ for a positive control. Twenty hours after infection or camptothecin addition, p53 and the viral E2A protein were detected by immunofluorescence. Nuclei were visualized by DAPI. 


\section{Conformation}

For its function as a transcription factor, p53 requires an active conformation. When mutated in cancer, p53 frequently looses its native conformation and thus its ability to bind DNA. These structural mutants display various epitopes that are normally hidden, and one of these is reactive with the monoclonal antibody 240. To define whether E1B$55 \mathrm{kDa}$-deleted viruses accumulate p53 in inactive or mutant-like conformation, immunoprecipitation analysis with antibodies, recognizing wild type (1620) versus mutant (240) conformation of the protein, was performed. We thereby found that p53 retains wild type conformation after infection (Fig. 12).

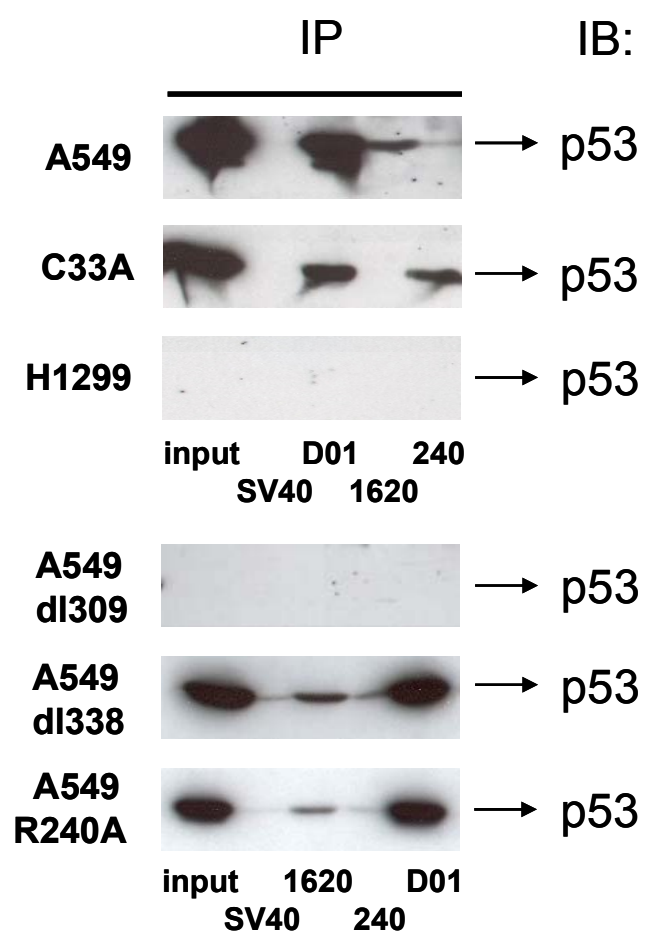

Fig. 12. p53 possesses wild type conformation after infection. A549 cells were mockinfected or infected with the indicated adenovirus mutants at a MOI of 20 . Twenty-four hours after infection, cells were harvested and subjected to immunoprecipitation (IP) with conformation-specific antibodies to p53: 1620 for wild type p53, 240 for mutant p53. DO1 antibody recognised both mutant and wild type p53 forms. p53 levels were detected by immunoblot analysis (IB) with D01 antibody, conjugated to HPR. C33A cells, bearing a p53 mutation recognised by the 240 antibody, were used as a positive control. p53 null H1299 cells and 419 anti-T antigen antibody served as negative controls. 


\section{Oligomerization}

The p53 protein exists mostly as a tetramer, and oligomerization of p53 is required for its adequate function in cells. We tested the ability of p53 to form oligomers after infection with E1B-55 kDa-mutant viruses. To this end, we used glutaraldehyde cross-linking, followed by SDS-PAGE and immunostaining with anti-p53 1801 antibodies. p53 from infected cells was compared with transiently expressed wild type p53 or a mutant that lacks a functional oligomerization domain ( $p 53-\Delta O ; \Delta 327-347$ (Atz et al., 2000)). As shown in Fig. 13, p53 from infected cells, as well as wild type p53, could be detected in two bands (around $55 \mathrm{kDa}$ and and $130 \mathrm{kDa}$ ) that correspond to monomeric and dimeric p53. In contrast, the oligomerization mutant was only found in a monomeric form, validating the assay. This argues against the idea that the virus disturbs the oligomerization of p53.

\section{Phosphorylation at key serine residues}

It has been repeatedly shown that both genotoxic and non-genotoxic stresses induce different posttranslational modifications of the p53 protein. These modifications are believed to stabilize and activate p53. The most well-known of them are phosphorylations at Ser-15 (by DNA-PK and ATM/ATR) and Ser-46 (by HIPK2) (Bode and Dong, 2004). We detected these modifications on p53 from infected cells by immunoblot analysis and found that p53 is phosphorylated at these residues to a degree comparable with camptothecin-treated cells (Fig. 14). 


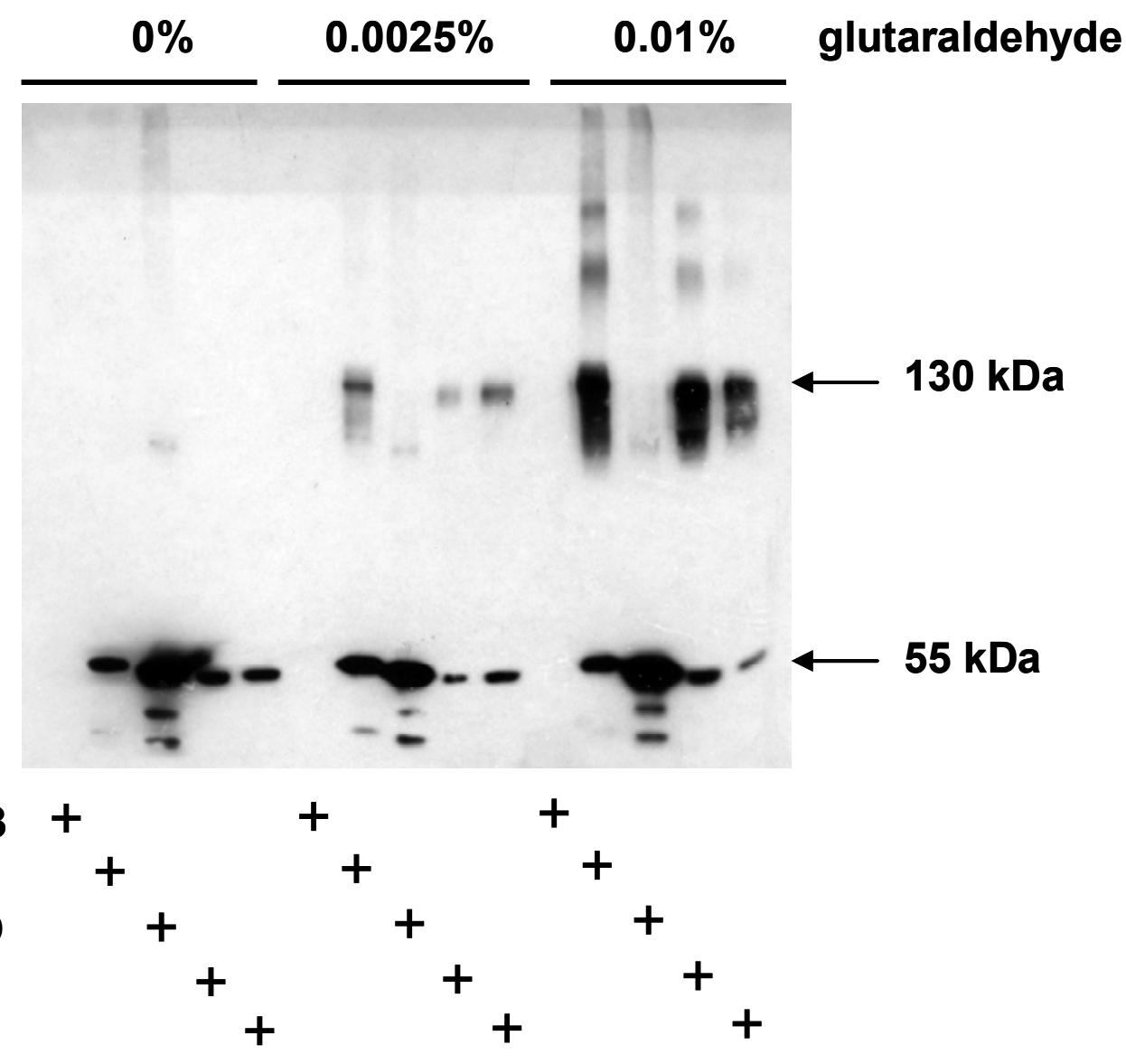

Fig. 13. p53 forms oligomers after infection. A549 cells were mock-infected or infected with the indicated adenovirus mutants at a MOI 20. The oligomerization state of p53 was assessed by glutaraldehyde cross-linking. Twenty-four hours after infection, cells were harvested, treated with glutaraldehyde for $15 \mathrm{~min}$, and subjected to SDS-PAGE analysis. Cross-linked and monomeric p53 was then detected by immunoblot with the 1801 antibody. To control the experiment, p53 from virus-infected cells was compared to p53 from H1299 cells, that were transfected either with a plasmid coding for wild type p53 (p53, positive control) or oligomerization mutant ( $553 \Delta 0$, negative control). Empty plasmid pCDNA3 was used as a negative control of the transfection. 


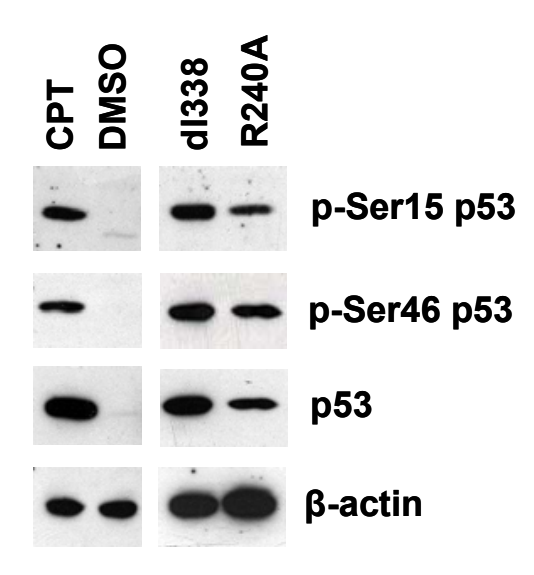

Fig. 14. p53 is phosphorylated at key serins after infection. A549 cells were mock-infected or infected with the indicated adenovirus mutants at a MOI of 20 . Twenty-four hours after infection or camptothecin addition $(300 \mathrm{nM})$, the phosphorylation of p53 was analysed by immunoblot staining with phospho-specific antibodies to p53.

Taken together, all properties of p53 under study were compatible with its active state. Nonetheless, p53-mediated transcriptional activation is blocked by E1B-55 kDa mutant adenoviruses.

\subsubsection{Adenoviral and cellular proteins involved in p53 inactivation after infection}

\section{E1A-deletion mutants}

The next step was to identify viral and cellular components that are involved in the process of p53 inactivation after infection with E1B-55 kDa-deleted viruses. From the virus side, we considered proteins of the E1A-familiy to be the most promising candidates for p53 regulation. E1A proteins are capable of affecting p53 levels and activity in a highly context dependent manner, most probably by recruiting basic transcription factors and co-activators that might contribute to p53 activity.

To understand the involvement of E1A proteins in p53 blockage during virus infection, we compared a panel of Ad5 viruses, carrying E1A mutations combined with a deletion 
of the E1B gene (schematically presented in Fig. 15), regarding their ability to block p53 activity. Using these mutants, we pursued several aims. First, we intended to separate the function of small $12 S$ from the large 13S E1A protein towards p53 inactivation. Second, we were interested whether adenovirus interferes with the function of histone acetyltransferase p300 that was reported as an essential cofactor for transcriptional activity of $p 53$. For this we tested E1A virus mutants that no longer bind $p 300$ in their ability to restore $\mathrm{p} 53$ activity. Apart from E1A deletions, these mutants also contain the deletion of another E1B gene product, the small antiapoptotic E1B-19 kDa protein. However, we observed that the additional deletion of E1B-19 kDa does not affect p21 and Mdm2 expression in the context of a E1B-55 kDa-mutant virus (Fig. 16).

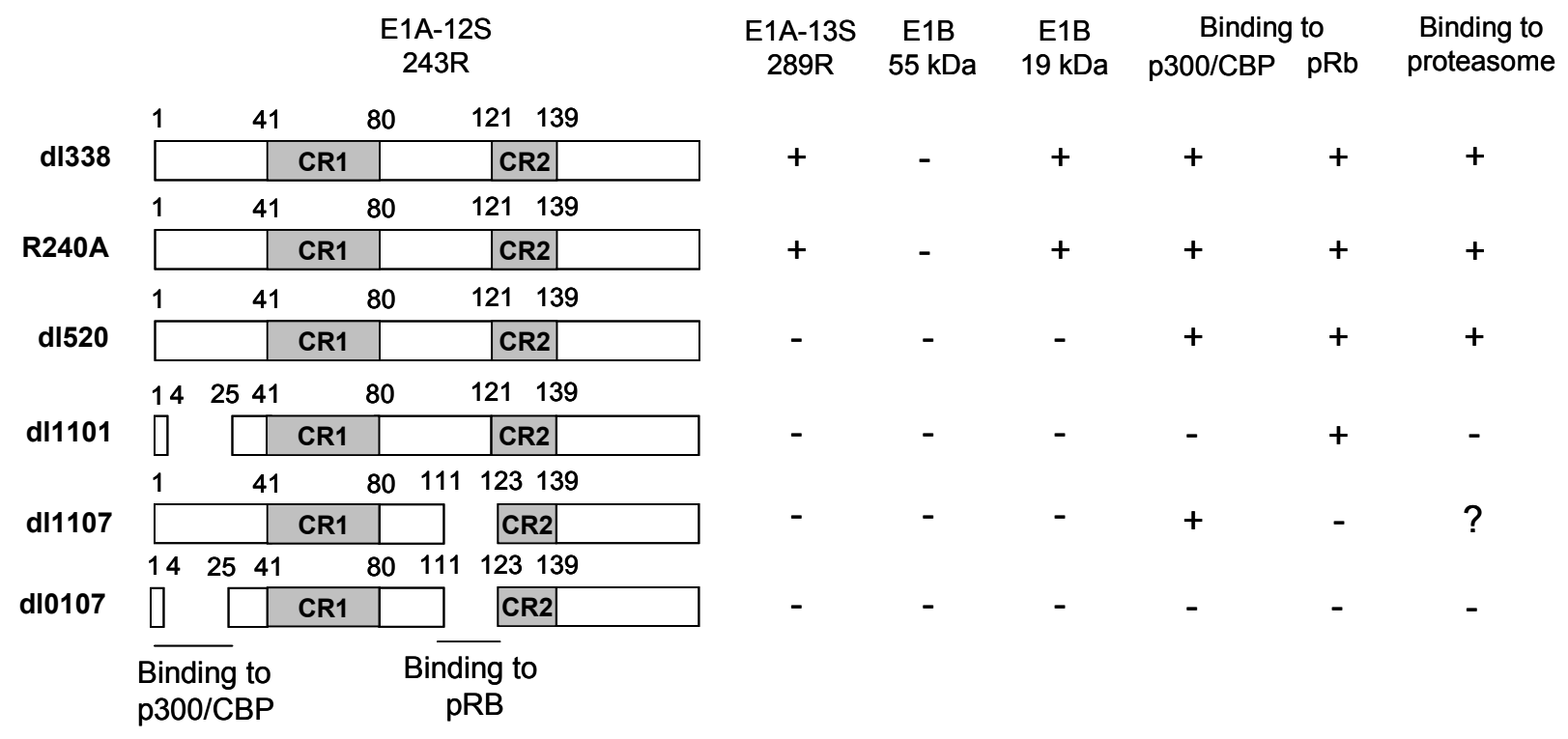

Fig. 15. E1A-deletion adenovirus mutants used in this study. Table of viruses under study, lacking the $\mathrm{E} 1 \mathrm{~B}-55 \mathrm{kDa}$ coding region and bearing different deletions in the E1A region along with the capabilities of E1A mutants to interact with p300/CBP, Rb and proteasome (? - nonstudied).

\section{E1A-13S down-regulates p21 and mdm2 mRNA levels upon infection}

After infection of A549 cells with the panel of virus mutants, we analysed the expression of two p53-activated genes, $p 21$ and $m d m 2$, by real time PCR and western blotting. We found out that, on the mRNA level the 13S E1A protein was responsible for blocking p21 
and Mdm2 expression, because E1A mutant viruses containing both 12S and 13S E1A proteins reduced p21 and Mdm2 mRNA levels more than 10 fold, whereas mutants bearing only E1A-12S were up-regulating p21 and Mdm2 mRNA by 2-4 fold, compared to mock-infected cells (Fig. 17, Q-RT-PCR panel). However, despite mRNA upregulation, E1A-12S-containing adenovirus blocked p21 and Mdm2 protein accumulation (Fig. 17, IB panel, dl520 virus).
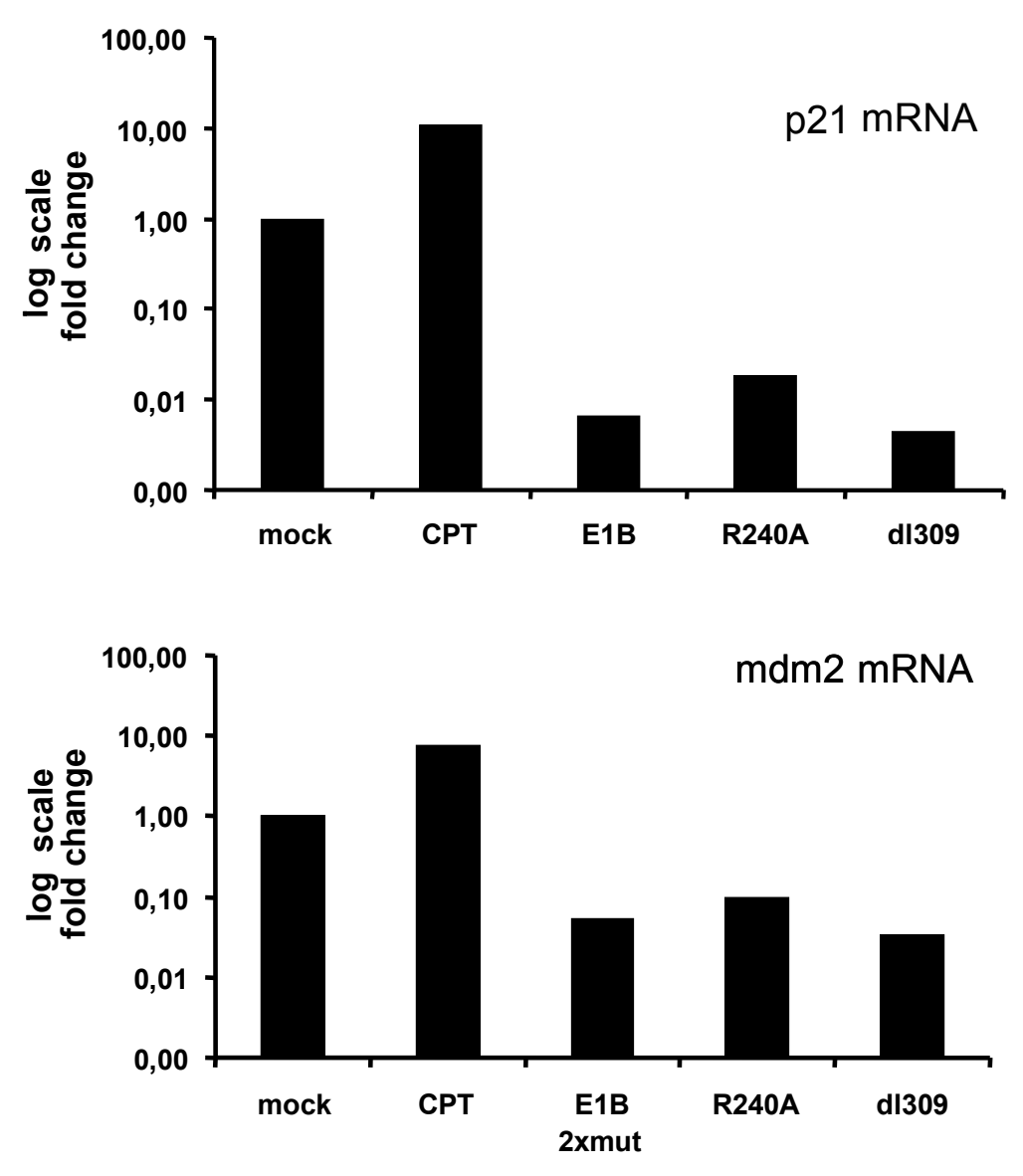

Fig. 16. A role of E1B-19 $\mathrm{kDa}$ in the regulation of $\mathrm{p} 21$ and $\mathrm{mdm} 2$ expression. A549 cells were mock-infected or infected at a MOI 50 with wild type dl309, mutant R240A or E1B 2xmut, bearing R240A in the E1B-55 kDa gene, and a deletion of E1B-19 kDa. For a positive control, cells were treated with camptothecin $(300 \mathrm{nM})$. Thirty-six hours post-infection, the cells were harvested and subjected to total RNA isolation, reverse transcription and real time PCR. Data represent Mdm2 and p21 mRNA levels, normalized to GAPDH. 


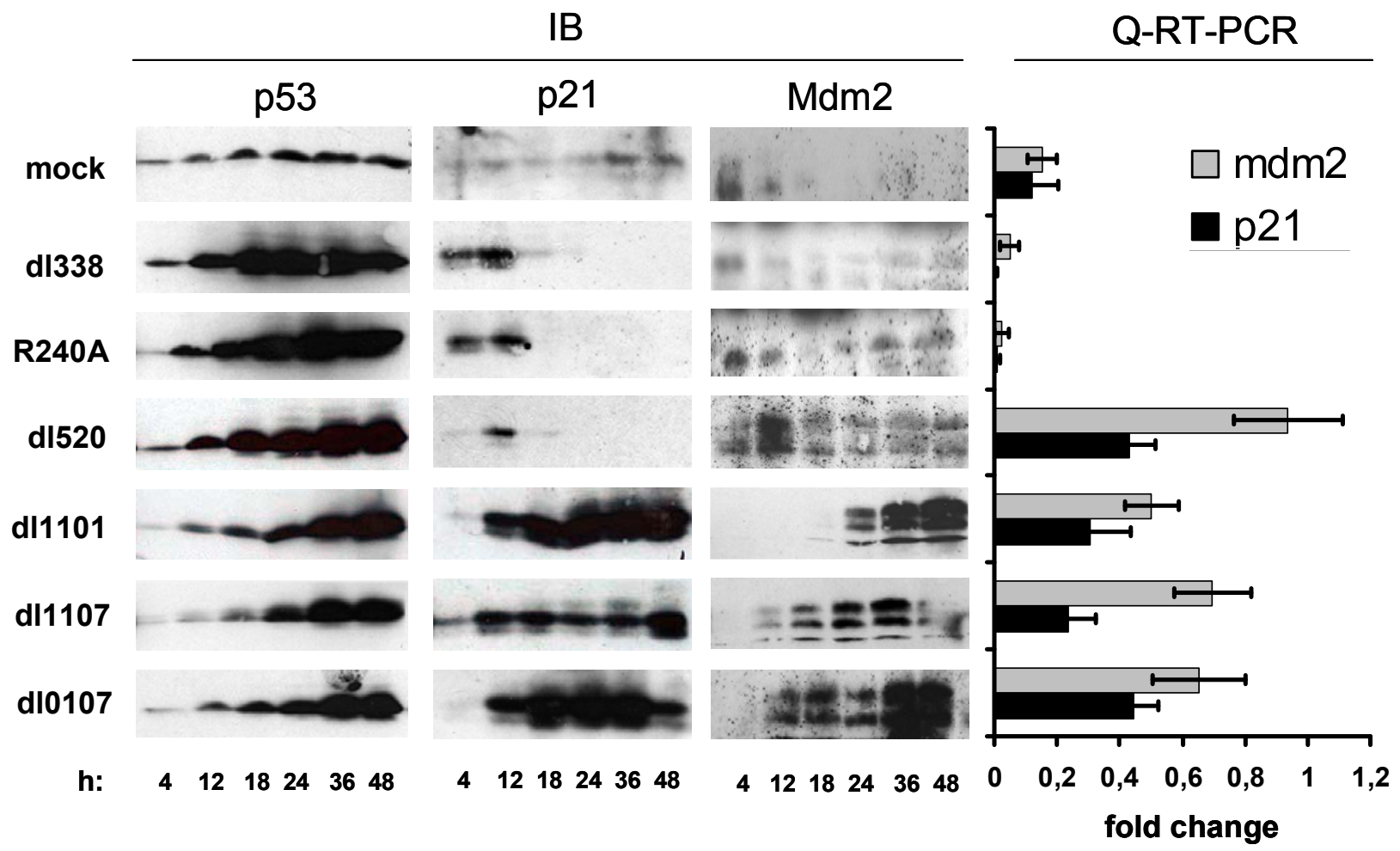

Fig. 17. p21 and mdm2 mRNA and protein levels after infection with E1A-deleted adenoviruses. A549 cells were mock-infected or infected with E1A-mutant adenoviruses, depicted at Fig. 15, at a $\mathrm{MOI}$ 50. At the indicated time points post infection, the cells were harvested and subjected to immunoblot analysis (p53 (D01 antibody), p21 and Mdm2 stainings, IB) or, 36 hours after infection, total RNA was reverse transcribed and analysed by real-time PCR. Data represent Mdm2 and p21 mRNA levels, normalized to GAPDH. Mean values from three independent experiments are shown with standard deviations.

In contrast, p21 and Mdm2 protein levels were restored upon infection of cells with viruses that express E1A-mutants with deletions in the amino-terminal part or the CR2 domain (dl1101, dl1107 and dl0107), perhaps as a result of proteasome blockage by these E1A regions (Turnell et al., 2000). We conclude that E1A proteins use a two-fold mechanism to regulate the expression of p53 target genes. E1A-13S through its CR3 region (the only region that is different between $12 \mathrm{~S}$ and $13 \mathrm{~S} \mathrm{E} 1 \mathrm{~A}$ proteins) blocks the accumulation of p21 and Mdm2 mRNA. However, when E1A is expressed only in its $12 \mathrm{~S}$ isoform, this prevents p21 and Mdm2 protein accumulation, despite elevated levels of mRNA. 


\section{E1A-13S inhibits pro-apoptotic PUMA on the level of mRNA}

p53 is known to induce genes, involved in cell cycle arrest, apoptosis and senescence. p21 protein belongs to the cell cycle arrest group of genes that are regulated by p53. To test whether pro-apoptotic p53 target genes are regulated the same way as p21 and mdm2 after infection, we performed real time PCR analysis of PUMA mRNA. Two adenovirus mutants were used in this study: dl338 and dl520, to test the importance of E1A-13S in the regulation of PUMA transcription. It was found that PUMA is 6 -fold upregulated after upon infection with dl520, containing only E1A-12S, whereas it was strongly down-regulated by the large E1A 13S-bearing virus dl338. We conclude that the large E1A protein is required for blocking PUMA mRNA accumulation (Fig. 18), in analogy to $p 21$ and $m d m 2$ gene regulation.

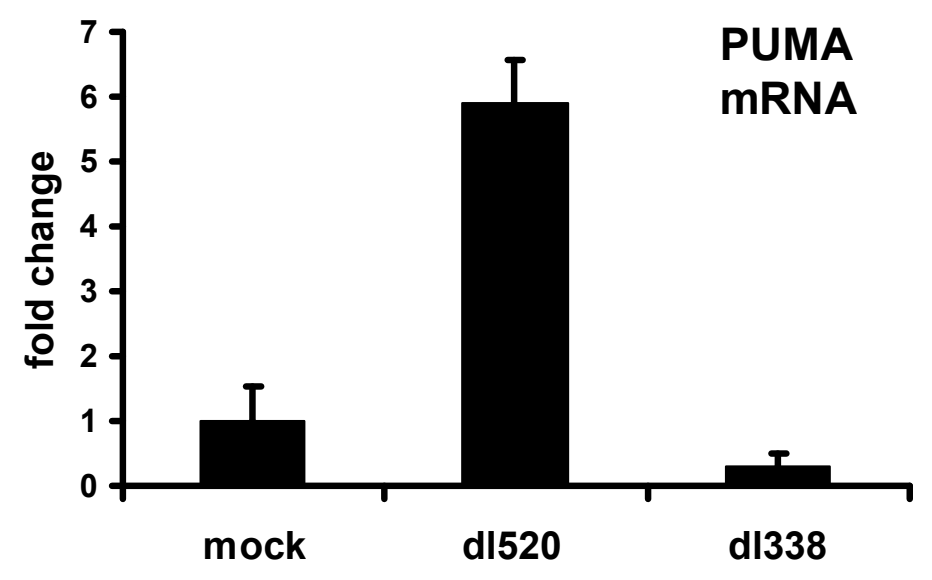

Fig. 18. E1A-13S is required for PUMA down-regulation at mRNA level. A549 cells were mock-infected or infected either with dl338 or dl520 at a MOI 50. Twenty-seven hours after infection, total RNA was reverse transcribed and analysed by real-time PCR. Data presents PUMA mRNA levels, normalized on GAPDH mRNA. Mean values from three independent experiments are shown with standard deviations. 
E1A-13S blocks p21 gene expression at the level of transcription, rather than at the posttranscriptional level

Next, we tested whether adenovirus blocked the transcription of p53-target genes or whether it interfered with mRNA processing. For this, we performed real-time PCR analysis of the pre-mRNA of the p21 gene, amplifying the mRNA samples from dl520- or dl338-infected cells with primers to the intron 1 of the p21 gene. p21 pre-mRNA levels were responding to the virus mutants much like the fully processed mRNA (Fig. 19), arguing that the regulation by E1A-13S occurs at the level of transcription, not RNA processing.

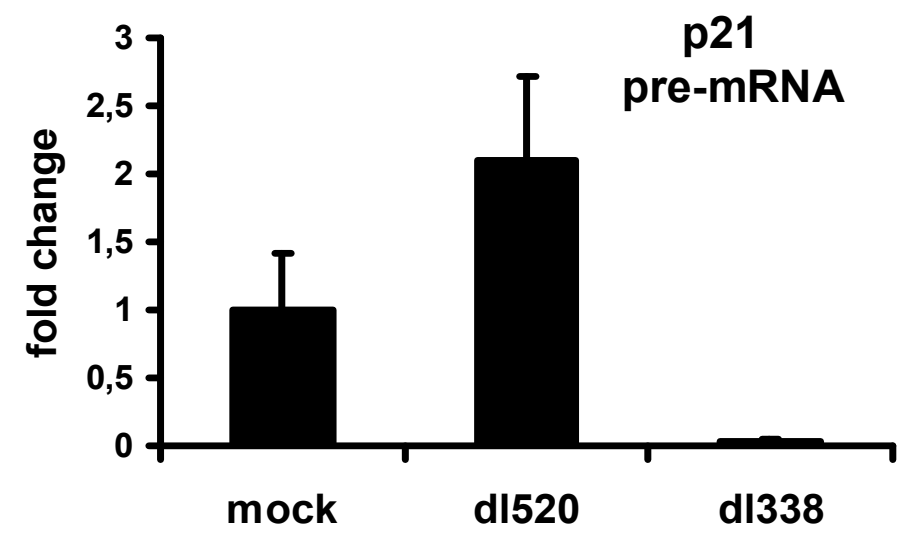

Fig. 19. p21 pre-mRNA levels are down regulated by E1A-13S after infection. The cDNA samples from Fig. 18 were subjected to real-time PCR and detection of pre-mRNA of p21 was performed, using primers to intron 1. Mean values from three independent experiments are shown with standard deviations.

p53-binding to its DNA-elements in the p21 promoter does not depend on E1A-13S

For further study, we focussed on two virus mutants that differ in ability to regulate p21 mRNA - dl338 and dl520. We examined how these virus mutants affect another important determinant of p53 activity - DNA-binding. Binding of p53 to its target DNA 
elements was analysed by chromatin immunoprecipitation. p53-associated DNA was quantified by real-time PCR with primers to the p53-binding site located at -2283 of the p21 promoter, upstream of the transcription start site. Surprisingly, despite accumulation of massive amounts of p53 (Fig. 20A), both dl520 and dl338 only permitted low p53DNA association, comparable with the non-infected samples, whereas the DNAdamaging agent camptothecin enriched p53 binding to the p21 promoter more than 10 fold (Fig. 20B). We conclude that adenovirus infection can generally prevent excessive p53-DNA complex formation despite the presence of high amounts of p53. However, this does not explain the differential p53 target gene expression upon infection with dl520 versus dl338.

\section{E1A-13S is responsible for removing Sp1 and RNA polymerase II from the p21 promoter}

The transcription of the $p 21$ and $m d m 2$ genes is also activated by the transcription factor Sp1. The p21 promoter is activated synergistically by p53 and Sp1 in several model systems (Lagger et al., 2003; Zhao et al., 2006). The E1A-13S protein, in turn, was reported to bind Sp1 within its CR3 region (Liu and Green, 1994). Thus, it was tempting to speculate that E1A -13S may impair Sp1 function in $p 21$ transactivation. We analysed the levels of Sp1 in infected cells and showed that both dl520 and dl338 viruses accumulated Sp1 protein (Fig. 20A). However, chromatin immunoprecipitation of Sp1 on the p21 promoter detected about 5-fold less Sp1 associated to the promoter, when the cells were infected with dl338 virus, containing E1A-13S, compared to dl520, bearing only E1A-12S (Fig. 20C). Similarly, the RNA polymerase II was removed from the p21 transcription start site after infection with dl338, but not after dl520 infection (Fig. 20D), suggesting that the presence of $\mathrm{E} 1 \mathrm{~A}-13 \mathrm{~S}$ reduces the formation of a functional transcription initiation complex. 
A

\section{mock dl338 dI520}

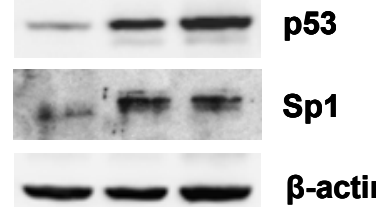

B
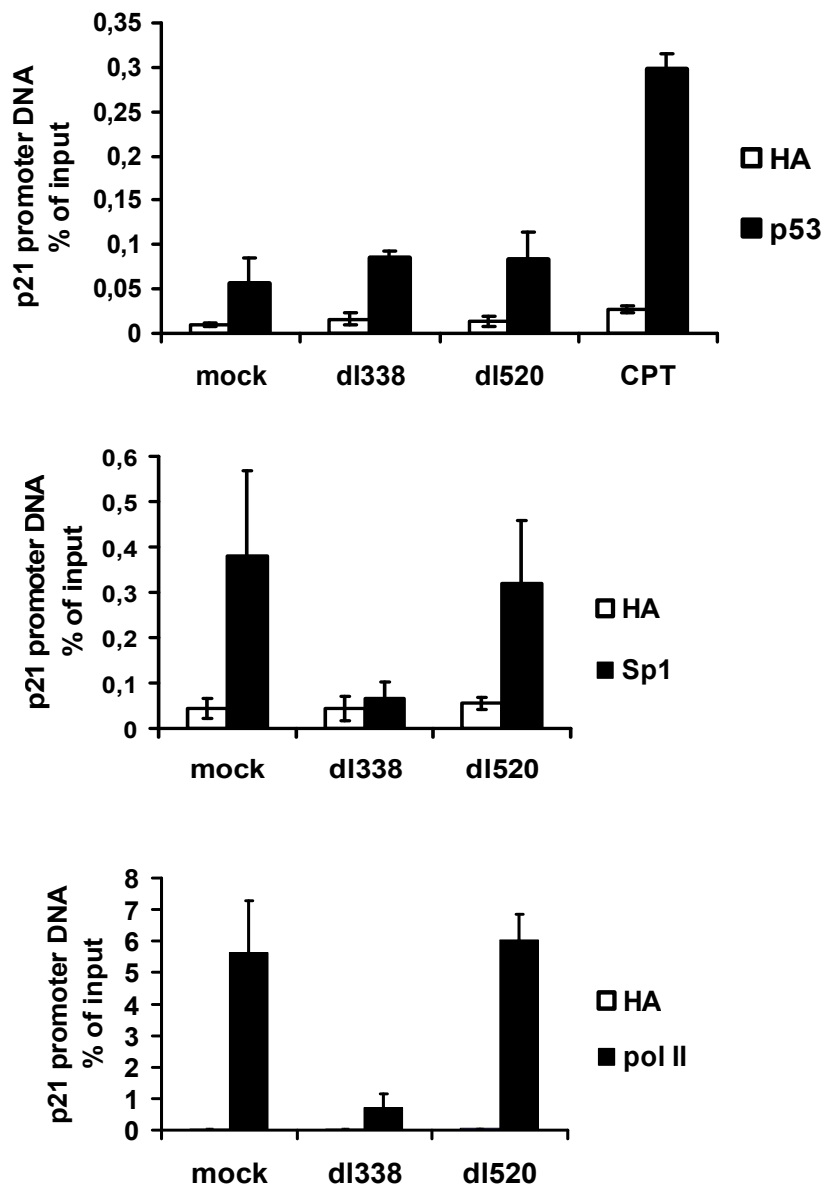

Fig. 20. Association of $\mathrm{Sp}-1$ and RNA polymerase II with the p21 promoter as a function of E1A-13S. A549 cells were mock infected, infected with dl338 or dl520 at a MOI 50, or treated with camptothecin $(300 \mathrm{nM})$ for 24 hours. Chromatin immunoprecipitation was performed with corresponding antibodies (D01 antibody for p53). Anti-HA-antibody was used as a negative control of precipitation. DNA binding was assessed by real-time PCR amplifying the corresponding promoter element. Mean values from three independent experiments are shown with standard deviations (B, D) or standard errors (C). A, A549 cells were infected with dl338, dl520 at a MOI 50, harvested and subjected to immunoblot detection of p53 and Sp1 proteins 24 hours post infection. B, p53 binding to its cognate p21 promoter element, located at -2283 upstream of the transcription start site. C, Sp1 binding at the transcription start site of the p21 gene. D, RNA polymerase II binding to the transcription start site of the p21 gene. 
Adenovirus blocks $\mathrm{p} 53$ acetylation at Lys 382 residue, using aminoterminal portion of E1A protein

Acetylation of p53 at lysine residues plays an important role in the transcriptional activity of the protein. Immunoblot analysis with antibodies recognizing p53 acetylated at position Lys382, after infection with dl338 or dl520, showed that both viruses prevent the acetylation of p53 at this residue even in the presence of the DNA-damaging drug camptothecin (Fig. 21). Interestingly, however, infection with adenovirus mutant dl1101, bearing an N-terminal mutation of E1A that prevents its binding to the histone acetyltransferase p300, allowed acetylation of p53 at Lys382 (Fig. 21). Thus, p300 binding by $\mathrm{E} 1 \mathrm{~A}$ represents a plausible mechanism for the missing p53 acetylation in infected cells.

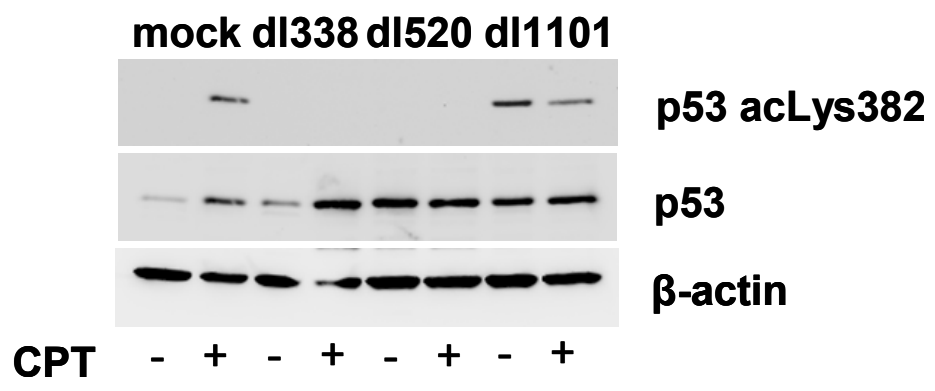

Fig. 21. Acetylation of p53 at Lys 382 after infection with adenovirus mutants. A549 cells were mock-infected, infected with dl338, dl520 or dl1101 at a MOI 50. For a positive control, cells were treated with camptothecin $(300 \mathrm{nM})$. Twenty-four hours after infection or CPT treatment, immunoblot analysis with the anti-acetyl-p53 (Lys382) or anti-p53 (D01) antibodies was performed. 
Blocking acetylation at Lys 382 is an additional way of inhibiting p53 activity by adenovirus, independent of E1A-13S

To understand whether acetylation of $p 53$ at Lys382 is required for p53-mediated transactivation even in the presence of E1A-13S protein, we analysed p21 mRNA levels after infection with adenovirus mutant E1A R2G. This mutant is derived from the adenovirus mutant R240A virus, carrying a E1B-mutation that abolishes p53 binding (Shen et al., 2001). In addition, the combined virus mutant contains E1A-13S with the point mutation $R$ to $G$ in the position 2, abolishing its interaction with $p 300$. As expected, the virus accumulated p53 with acetylated at Lys382 (Fig. 22A). Real-time PCR analysis of p21 mRNA showed that E1A R2G mutant is able to restore p21 transcription at least to the level of mock-infected cells (Fig. 22B). This argues that the blockage of p53 acetylation by $\mathrm{E} 1 \mathrm{~A}$ represents another way by that the virus impairs p53 activity, independently of E1A-CR3 and E1B-55 kDa.

A

B
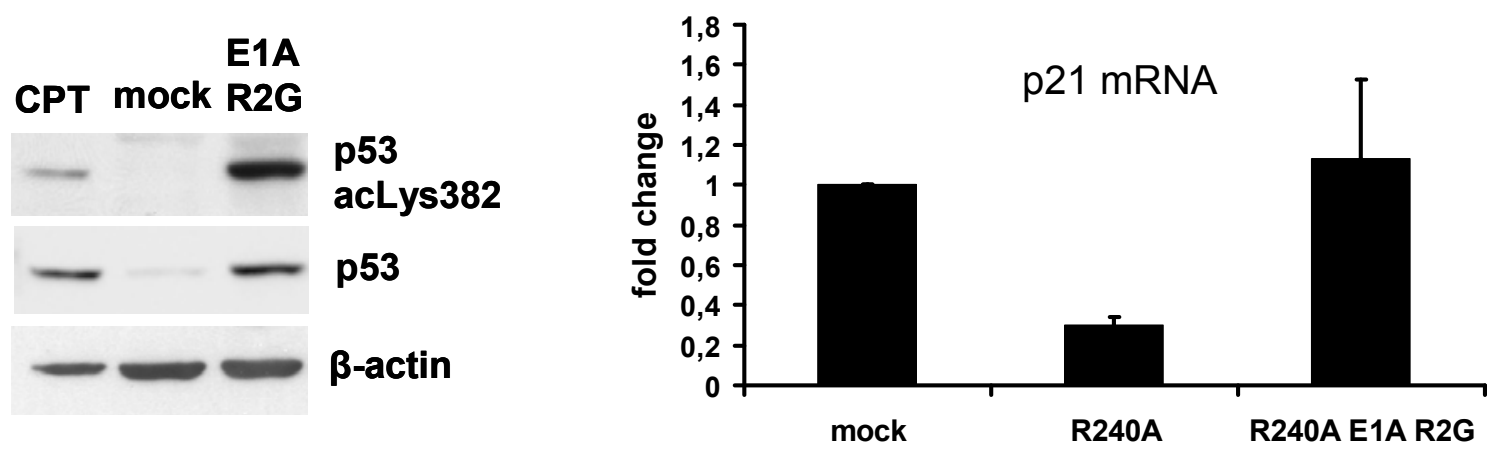

Fig. 22. E1A R2G virus accumulate p53, acetylated at Lys382 and allows p21 transcription. A549 cells were mock-infected or treated with camptothecin (300nM) for 24 hours or infected with adenovirus, carrying the E1B-55 kDa mutation $\mathrm{R}$ to $\mathrm{A}$ at residue 240 , in combination with the $E 1 A$ mutation $R$ to $G$ at position 2, resulting in strongly reduced p300 binding, at a MOI 20 for 36 hours. A, the cells were harvested and subjected to immunoblot detection of p53 with anti-acetyl-p53 (Lys382) or anti-p53 (D01) antibodies. B, Cells were harvested, total RNA was reverse transcribed and analysed by real-time PCR. Data represent p21 mRNA levels, normalized to mt-RNR2. Mean values from three independent experiments are shown with standard deviations. 


\subsection{Restoration of $p 53$ activity after infection}

\subsubsection{HDAC inhibitor TSA increases p21 transcription after infection with dI338 virus}

Next, we wanted to assess, whether it is possible to reactivate p21 transcription after infection with E1A-13S virus. For that, we treated dl338-infected cells with TSA, a histone deacetylase inhibitor that was shown to activate p21 transcription through Sp1 sites (Liu and Green, 1994). We observed that TSA restored p21 transcription up to mock-infected level, whereas it did not increase p21 mRNA levels in the case of dl520 infection (Fig. 23A). To ensure that TSA treatment does not interfere with virus replication, immunofluorescence staining of viral DNA-binding E2A protein was performed. As depicted on Fig. 23B, dl338 virus is able to form replication centres in TSA-treated cells, meaning that up-regulation of p21 by TSA in infected cells is not a result of impaired virus replication.

\subsubsection{TSA restores RNA polymerase II binding to the p21 promoter start site}

In order to understand the mechanisms of TSA-mediated induction of p21 transcription after infection with dl338-virus, we analysed the binding of RNA polymerase II to the transcription start site of the p21 promoter. Chromatin immunoprecipitation of RNA polymerase II after 24 hours of infection with dl338 virus and 21 hours of TSA treatment was performed. As depicted on Fig. 24A infection with dl338 virus cells leads to complete removal of RNA polymerase II from the p21 promoter. However, TSA restored RNA polymerase II binding to the transcription start site of the p21 promoter after infection up to the level, two fold exceeding that in mock-infected cells. 


\section{A}

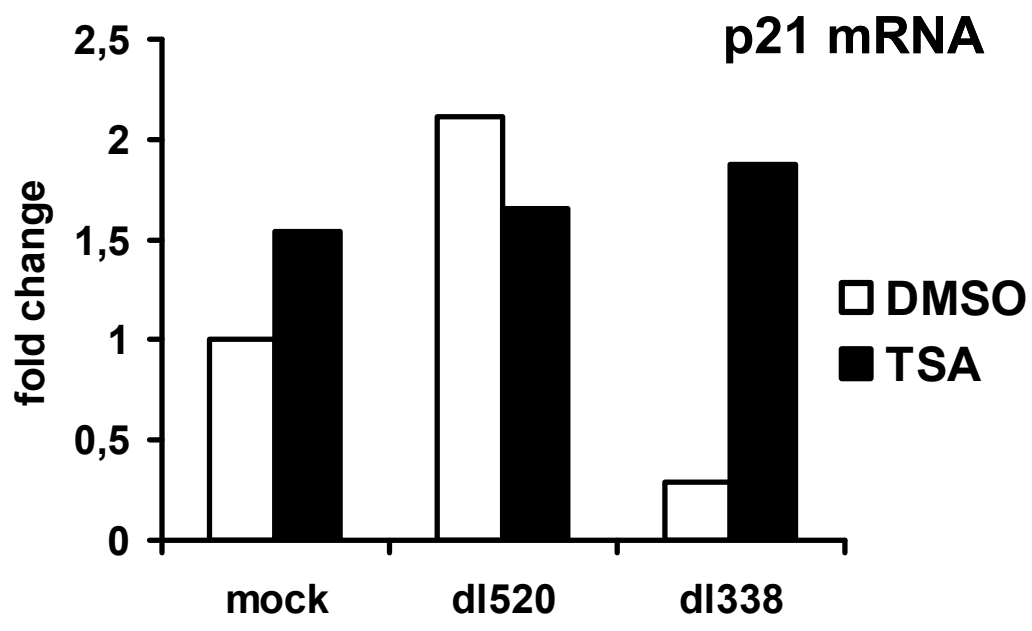

A549 cells, dl338 24h of infection
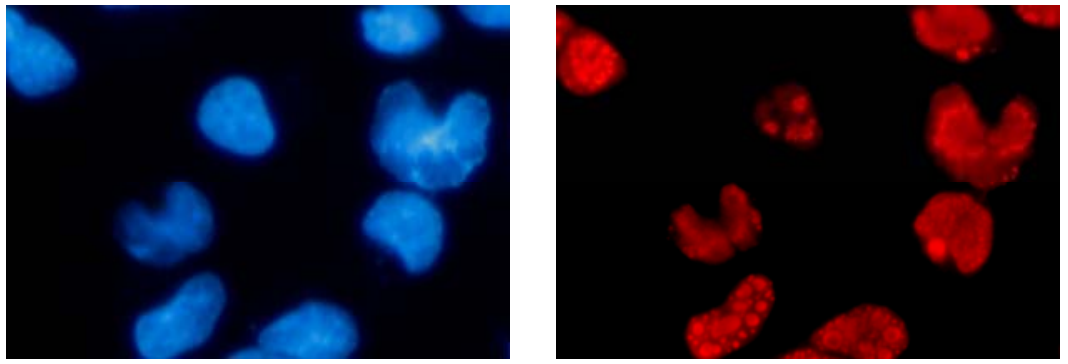

DMSO

21h
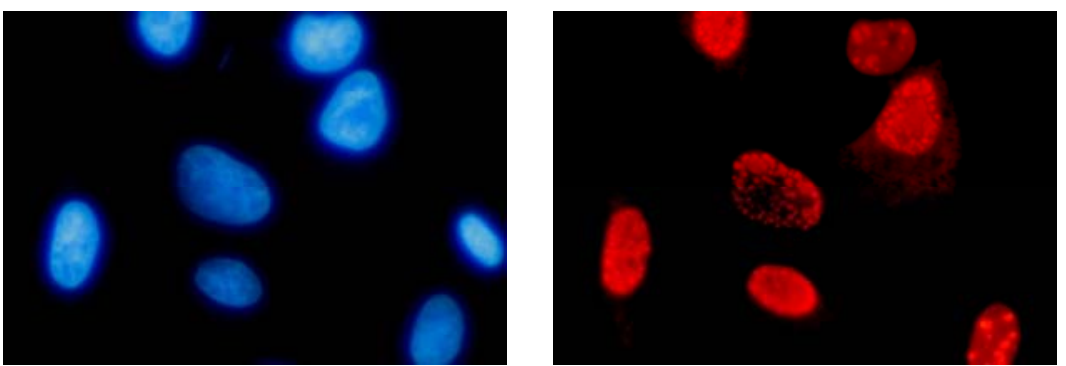

TSA

21h

DAPI

E2A

Fig. 23. p21 mRNA levels in infected cells, treated with TSA. A549 cells were mock-infected, infected with dl520 or dl338 virus for 3 hours then TSA (300nM) was added for 21 hour. A, Cells were harvested, total RNA was isolated, reverse transcribed and CDNA was analysed by realtime PCR. Data represent p21 mRNA levels, normalized to mt-RNR2. B, Adenoviral E2A protein was detected by immunofluorescence. Nuclei were visualized by DAPI. 


\subsubsection{Adenovirus induces acetylation of $\mathrm{H} 3$ and $\mathrm{H} 4$ histones at $\mathrm{p} 21$ promoter}

TSA is believed to activate transcription by inhibiting histone deacetylases and therefore sustaining acetylation of histones in the promoter regions of the activated genes. This may lead to the relaxation of the chromatin structure and facilitate the recruitment of basic transcription factor machinery to the promoters. We therefore tested, whether the lack of acetylation of core histones $\mathrm{H} 3$ and $\mathrm{H} 4$ may be a reason for blocking $\mathrm{p} 21$ activity by adenovirus and whether TSA may restore this acetylation to allow the loading of RNA polymerase II to the p21 promoter transcription start site and p21 transcription. For this, chromatin immunoprecipitation of histones $\mathrm{H} 3$ and $\mathrm{H} 4$ was performed in cells, infected with dl338 virus and subsequently treated with TSA. Real-time PCR analysis showed that proximal site in p21 promoter contains surprisingly high levels of $\mathrm{H} 3$ and $\mathrm{H} 4$ acetylation, comparable with cells, treated with DNA-damaging drug CPT (Fig. 24B). Treatment with TSA increased, to a certain extent, the acetylation of $\mathrm{H} 3$ histone and surprisingly decreased $\mathrm{H} 4$ acetylation after infection. Thus, we conclude that deacetylation of core histones can not be the reason for blocking p21 transcription by adenovirus. 


\section{A}

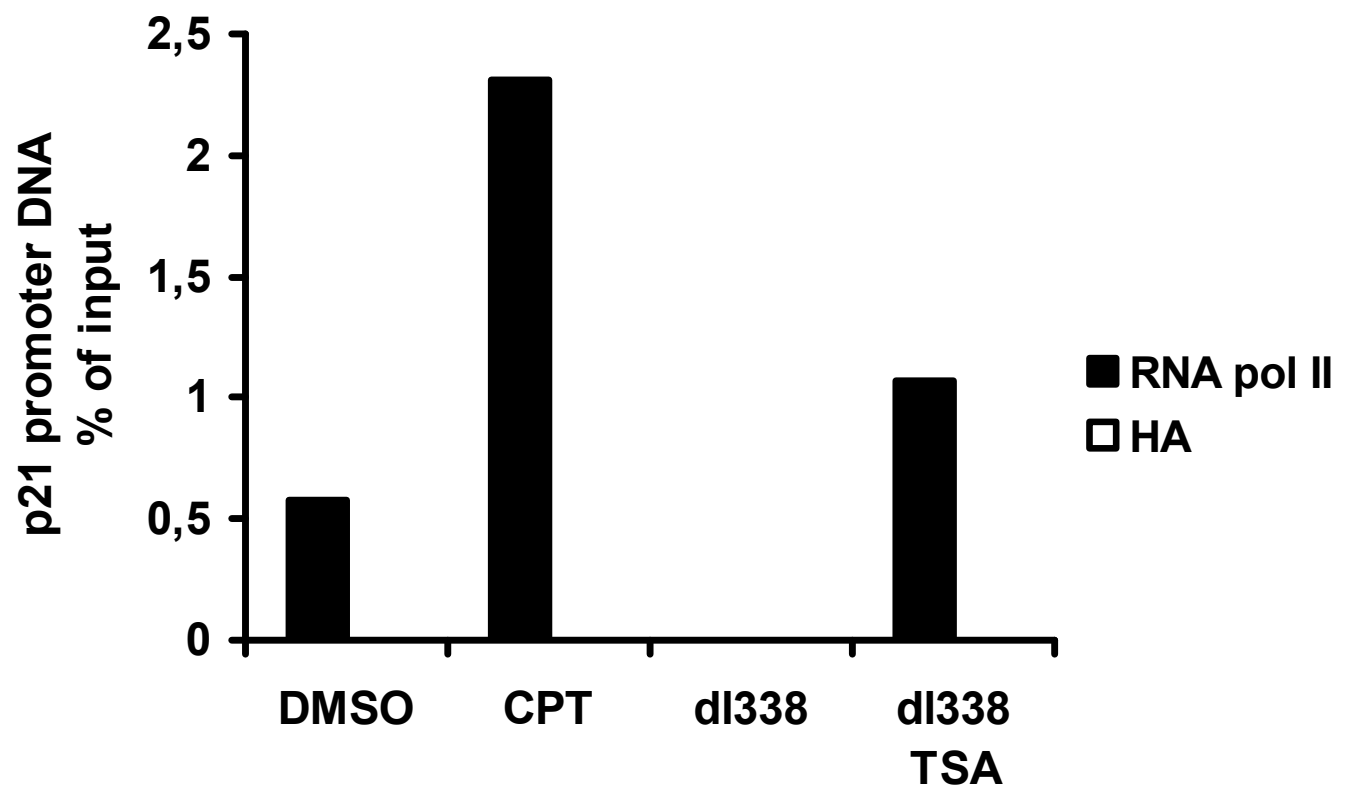

B

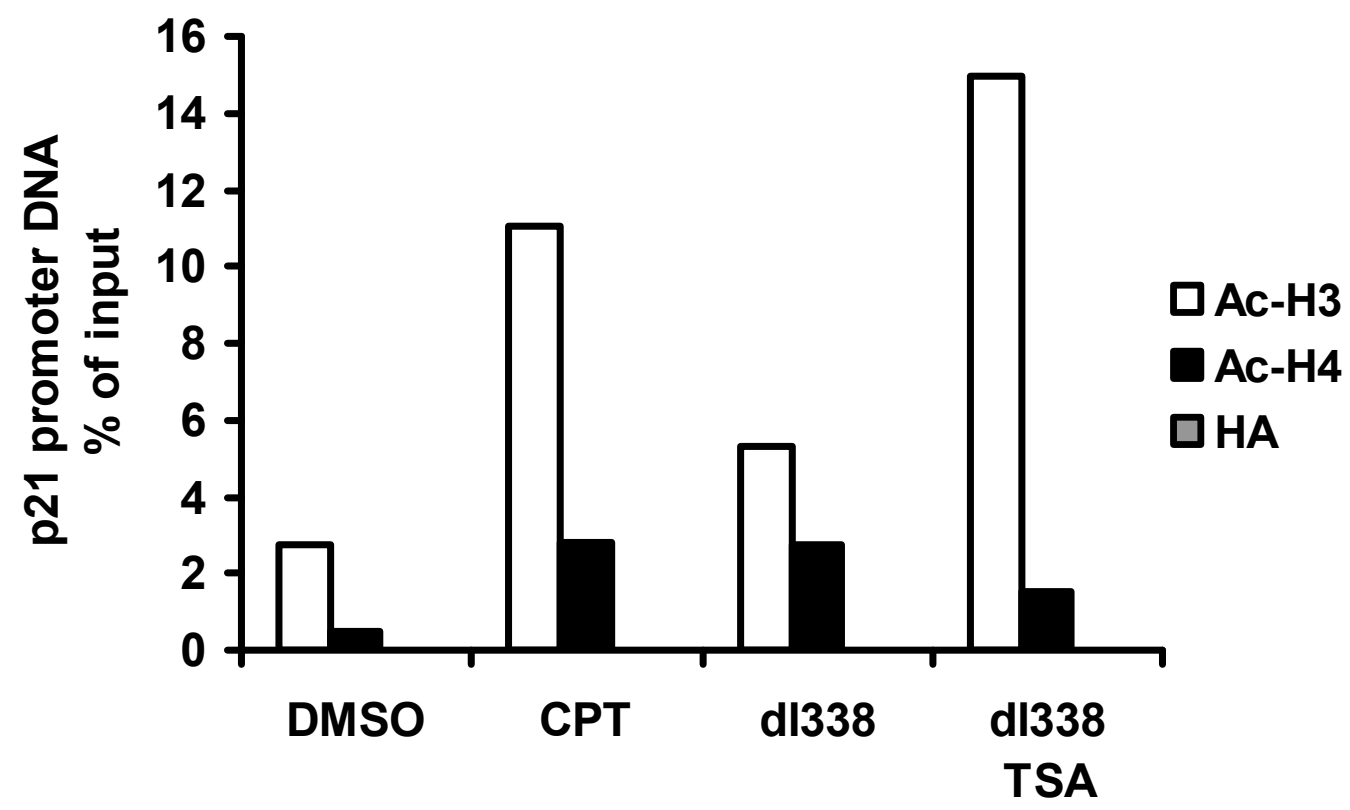

Fig. 24. RNA polymerase loading and acetylation of $\mathrm{H} 3$ and $\mathrm{H} 4$ core histones in dl338infeted cells, treated with TSA. A549 cells were mock-infected, infected with dl520 or dl338 virus for 3 hours then TSA (300nM) was added for 21 hour. Chromatin immunoprecipitation was performed with antibodies, recognising RNA polymerase II (A) or acetyated forms of $\mathrm{H} 3$ and $\mathrm{H} 4$ histones (B). Anti-HA-antibody was used as a negative control of precipitation. DNA binding was assessed by real time PCR amplifying the transcriptional start site $(\mathbf{A})$ or proximal site on p21 promoter (B). 


\section{Discussion}

\subsection{Accumulation of $p 53$ after infection with adenovirus}

Adenovirus infection brings a large amount of exogenous double stranded virus DNA into the cells, which is apparently perceived as DNA double strand breaks by cellular machinery. Moreover, adenovirus expresses oncogenes that were shown to induce DNA-damage response in tumour cells. Therefore, it is not a surprise that DNA-damage pathways are activated and p53 accumulates in cells infected with virus mutants that lack the main adenoviral inhibitor of p53, E1B-55 kDa. We showed here that the virus does not change mRNA levels of p53, whereas infection stabilizes the p53 protein. This conclusion agrees with the generally accepted mechanism of p53 stabilization after DNA damage that includes phosphorylation of p53, prevention of p53-Mdm2-interaction and thus inhibition of p53 degradation. We suspect that adenovirus interferes with Mdm2 activity, at least in part through phosphorylation of p53 at key serines and inhibition of its interaction with Mdm2. It was also shown that phosphorylation of p53 at Ser15 inhibit its nuclear export signal located in the N-terminus (Zhang and Xiong, 2001), thus suggesting a mechanism for p53 accumulation in the nucleus that we observe after infection (Fig. 11). However, a time course analysing p53 phoshorylation after infection is required to find out, whether the phosphorylation may precede and thus cause p53 stabilization. It is also possible that attenuated expression of Mdm2 contributes to the phenomenon of p53 stabilization. Although Mdm2 mRNA is most strongly reduced by viruses that carry wild type E1A-13S, p53-mediated gene expression seemed attenuated even when E1A-deletion mutant viruses, allowing Mdm2 transcription, were studied. Indeed, genotoxic treatment with camptothecin consistently activated p53responsive genes to higher levels than even adenovirus mutants that allowed transcriptional activity of $p 53$, despite comparable p53-levels. This may be explained by a strong decrease in the DNA-binding ability of p53 after infection. We therefore suspect that the virus has even more ways of counteracting p53 activity than analyzed here, thus attenuating Mdm2-expression and leading to p53 stabilization.

Several attempts were made previously to uncover viral proteins required for p53 accumulation. Mainly, this was done by transient transfection of viral oncogenes into 
cultured cells. It was found that E1A proteins then induce the stabilization of p53 and subsequent apoptosis of the transfected cells (Lowe and Ruley, 1993). The idea explaining this phenomenon was that $\mathrm{E} 1 \mathrm{~A}$ proteins may bind to several components of the proteasomal machinery and therefore inhibit the degradation of several proteasomal substrates, including p53. The transient expression of E1A-genes with deletions, coding for the proteins that no longer bind the proteasome, indeed, decreased the protein levels of p53 (Zhang et al., 2004). However, as we showed here, this does not happen during infection with virus mutants containing the same E1A-deletions. It is possible that E1A then stabilizes p53 through a different mechanism, forming a triple complex with Mdm4 and enhancing nuclear retention of p53 after infection, as was suggested by $\mathrm{Li} Z$. and colleagues based on yeast two-hybrid and transient transfection data ( $\mathrm{Li}$ et al., 2004). However, E1A reportedly binds to Mdm4 with its CR1 region, and thus, we can not assess the impact of E1A-Mdm4-interaction on p53 stabilization by this study.

\subsection{Inactivation of p53 after adenovirus infection}

The presence of direct p53 antagonists in small DNA tumor viruses has led to the discovery of p53 in the first place, initiating a new epoch of cancer research. It therefore came as a big surprise that adenoviruses lacking p53-binding E1B-55 kDa still abolish the efficient expression of p53-responsive genes, despite the accumulation of p53 in unusually high amounts (Hobom and Dobbelstein, 2004). The results presented in this study largely explain this seeming contradiction. We found that, in addition to E1B-55 $\mathrm{kDa}$, the E1A gene products also antagonize p53 during infection. Although E1A proteins do not form detectable complexes with p53, they avoid p53 activity at least in two ways. Firstly, the E1A CR3 region mediates p53 inhibition, and it interferes with Sp1promoter-interactions. Secondly, E1A interferes with p53 acetylation through its aminoterminal, p300-binding region. Both activities of E1A largely block p53 even in the absence of a direct p53 antagonist E1B-55 kDa. It should be pointed out that this scenario reflects the situation of an infected cell, not oncogenic transformation by the virus $E 1$ region. In the latter case, it has long been known that $E 1 A$ induces apoptosis largely through p53 (Debbas and White, 1993). However, infected cells contain much 
higher amounts of virus proteins than transformed cells, with little time for the host cell to adapt the levels of cellular E1A-binding proteins. We propose that this scenario leads to p53-attenuation by E1A. Of note, it has not been tested whether apoptosis after transfection of E1A genes requires transcription of the p53 targets or rather represents transcription-independent functions of p53 at the mitochondria. In the latter case transient E1A expression would accumulate transcriptionally inactive p53, as we observe after infection with the E1B-55 kDa-deleted viruses.

\subsubsection{Inactivation of p53 through E1A-13S}

A detailed comparison of virus mutants revealed that the $C R 3$ region of the E1A protein is a major determinant of how p53-responsive genes are transcribed in the absence of E1B-55 kDa. Only the virus mutants that retained the E1A-13S isoform - the sole isoform containing CR3 - were still blocking the expression of such genes. Viruses without E1A-13S were still capable of interfering with p53 acetylation but nonetheless allowed p53-induced gene expression. CR3 has long been known for its capability of interacting with numerous cellular proteins, involved in the regulation of transcription. The most interesting of them, bridging adenovirus activity with p53-mediated transcription activation, is transcription factor $\mathrm{Sp} 1 . \mathrm{Sp} 1$ is ubiquitously expressed and regulates transcription, synergistically interacting with different transcription factors, coactivators and TAFs. Sp1 binding sites were found in the promoters of many p53-target genes ( $p 21, m d m 2, P U M A, B a k$, etc.) and it was also shown to physically interact with p53 and synergistically activate some of the p53 target promoters after DNA damage (Koutsodontis and Kardassis, 2004; Lagger et al., 2003; Zhao et al., 2006). A cancerassociated polymorphism affects the interaction of Sp1 with the Mdm2 promoter, showing that this interaction is crucial for proper regulation of p53 activity (Bond et al., 2004). On the other hand, Sp1 was shown to bind the CR3 region of E1A-13S (Liu and Green, 1994) and activate transcription from early (Schmidt et al., 1989) and late viral (Parks and Shenk, 1997) promoters. These observations raise the possibility that E1A antagonizes $p 53$ by eliminating $S p 1$ activity, probably by binding to $S p 1$ and recruiting it from cellular to viral promoters. We found that Sp1 expression is increased during infection, and in agreement with the model, Sp1-DNA interaction at the p21 promoter 
was strongly diminished as a function of E1A-13S. These observations do not exclude the interaction of CR3 with other proteins as an additional mechanistic basis for p53 inactivation. It is also possible that E1A, via the CR3 domain, disrupts Sp1-p53 complex formation, since CR3 binds the same region of Sp1 that is required for interaction with p53 (Lagger et al., 2003; Liu and Green, 1994).

\subsubsection{Inhibition of p53 acetylation at residue Lys 382}

Additional mutational analysis revealed a CR3-independent activity of E1A towards p53. E1A eliminated any detectable p53 acetylation at K382, the p300-acetylation site (Ito et al., 2001). In contrast, when the aminoterminal, p300-binding region of E1A was mutated, p53 not only accumulated in infected cells but also displayed strong K382 acetylation, similar to cells undergoing genotoxic stress. Again, it is conceivable that the interaction of the E1A-aminoterminal region with other partners in addition to p300 and the related CREB-binding protein (CBP) may contribute to the lack of p53 acetylation, e. g. the histone acetyltransferase PCAF. However, p300 is one of the earliest proteins found to bind E1A with high efficiency (Harlow et al., 1986), and its role in p53 activation is well-documented (Avantaggiati et al., 1997; Lill et al., 1997). In any case, this function of E1A was required for full suppression of p53-responsive genes even when the $13 \mathrm{~S}$ isoform of $E 1 A$ was present. This strongly suggests that the aminoterminal region and the CR3 of E1A provide at least two independent but cooperating functions to antagonize p53 activity.

Acetylation of p53 seems to be critical for its activity, since many tumors and viruses evolved a strategy to prevent it, interfering with histone acetyltransferase activity. Here we examined only one lysine residue that was differentially acetylated during infection, but there could be much more affected acetylation sites. Therefore, a mass spectrometry analysis to detect the alterations of p53 postranslational modifications after infection is required for further investigations.

Finally, we also showed that adenovirus infection accumulates p53 that does not bind efficiently to its binding sites in target promoters, in the comparison with camptothecintreated cells. Though we do not know the mechanisms that adenovirus uses to block 
p53 DNA-binding activity, we suspect this could be an additional way of blocking p53dependent transcription. It is possible that the lack of acetylation at Lys382 after infection could be the reason for lack of proper conformation and therefore reduced DNA-binding of $\mathrm{p} 53$.

\subsection{Posttranslational inactivation of p53 target gene products by E1A}

In this work, we showed that E1A proteins regulate p53 target gene expression at the mRNA and protein levels. We found that, in addition to blocking transcription of p53 target genes by E1A-CR3 domain, N-terminus and to a lesser extent CR2-domain of $\mathrm{E} 1 \mathrm{~A}$ are responsible for down-regulation of $\mathrm{p} 21$ and Mdm2 proteins. This is detected after infection of cells with a deletion mutant dl520 that contains only small $12 \mathrm{~S}$ isoform of E1A. It is difficult to clarify whether E1A utilises a common mechanism for elimination p53 target proteins, e.g. interfering with proteasome activity or the mechanisms are different in any particular case. Alternatively, E1A may contribute to the elimination of individual p53 target gene products by different mechanisms. For example, p21 was reported to associate with E1A in transiently transfected cells, resulting in its inactivation but not elimination (Keblusek et al., 1999). We speculate that this interaction may foster degradation of p21 in infected cells, perhaps through association with functionally altered proteasomes.

\subsection{Inactivation of p53 in the absence of adenovirus infection}

Some of the mechanisms that directly attenuate p53 in adenovirus-infected cells may also abolish the tumour-suppressing function of p53 in cancer cells, especially when the cellular Mdm2 protein (representing the functional analogue to E1B-55 kDa) is not sufficiently expressed. Some cancer cells delete or mutate p300 and/or CBP, and CBPmutations form the basis for a syndrome of cancer-proneness (lyer et al., 2004), arguing that p300/CBP inactivation and a resulting lack in p53 acetylation may contribute to virus-independent cancer as well. Moreover, the MYC family of oncoproteins shows 
many functional analogies to E1A. MYC interacts with Sp1 and attenuates p21 expression (Gartel et al., 2001); moreover, it binds p300 (Faiola et al., 2005), perhaps modulating p53 acetylation. The mechanistic principles used by adenoviruses to attenuate p53 activity in infected cells may thus serve as guidelines for the definition of p53-inhibitory pathways in human cancer.

Adenovirus infection forces cells to perform continuous rounds of S-phase entry. Continuous S-phase induction may result in multiple errors in DNA replication, stalling replication forks, and subsequent intra S-phase check point induction. It was shown that infection of A549 cells with the Ad12 dl620 mutant, with a deletion in the E1B-55 kDa gene, leads to the accumulation of cells in S phase even 72 hours after infection (Grand et al., 1998). Although Ad5 E1B-deleted virus was not able to block rodent cells in Sphase (Shepherd et al., 1993), the cell cycle distribution after infection of human cells with this virus is unknown. From the other point, some chemicals and physiological conditions, e.g. hydroxyurea and hypoxia, that induce replication arrest, were shown to accumulate transcriptionally inactive p53 towards a list of target genes, including p21 (Koumenis et al., 2001; Mattia et al., 2007). Interestingly, it was shown that ATR kinase activity is required for p53 Ser15 phosphorylation and accumulation in S-phase arrested cells after hypoxia (Hammond et al., 2002), and ATR or Chk1 ablation rescued p21 mRNA and protein levels during the S-phase checkpoint after hydroxyurea treatment (Beckerman et al., 2009). All these data suggest that adenovirus may also interfere with ATR/Chk1-signaling and thus accumulate inactive p53 in S-phase. Therefore, the next step will be to test whether the adenovirus mutants under study perform S-phase arrest and whether chemical inhibitors of ATR/Chk1 pathways are able to restore p21 transcription after infection. Interestingly, hydroxyurea treatment was shown to induce acetylation of $\mathrm{H} 3$ and $\mathrm{H} 4$ histones at the $\mathrm{p} 21$ promoter, though the transcription of the p21 gene was blocked (Mattia et al., 2007). We also observe acetylation of $\mathrm{H} 3$ and $\mathrm{H} 4$ histones at the p21 promoter after infection, arguing that hydroxyurea and adenovirus may indeed use overlaping mechanisms of p53 inactivation. However, in the case of hydroxyurea, p21 transcription is blocked at the level of elongation (Beckerman et al., 2009), whereas we do not observe RNA polymerase II already at the transcription start 
site, suggesting an additional backup mechanism that adenovirus uses to block $p 21$ transcription.

\subsection{Restoration of p53 activity after infection}

To better understand the mechanisms of p53 inactivation by adenovirus, we searched for chemical compounds that reactivate p53-transcriptional activity after infection. We have shown that adenovirus interferes with Sp1 activity presumably blocking p21 promoter activity. It is known that some histone deacetylase (HDAC) inhibitors are able to activate p21 expression through Sp1-sites (Gartel and Tyner, 1999). One of them is Trichostatin A (TSA). We applied TSA 3 hours after infection with E1B-55 kDa-deleted dl338 virus. TSA was able to induce $p 21$ transcription after infection till the level of mockinfected cells. The exact mechanism of TSA action on p21 transcription is not clear, but there are suggestions that it blocks the activity of HDAC1, releasing it from Sp1-binding sites of the p21 promoter that correlates with acetylation of $\mathrm{H} 3$ and $\mathrm{H} 4$ histones with promoter region. However, we found that the acetylation of these histones was rather elevated, not suppressed by adenovirus, suggesting a relaxed chromatin structure at the promoter. Nevertheless, E1A-13S-containing dl338 adenovirus blocked RNA polymerase II binding to the p21 promoter that was restored by TSA. It was already described that TSA-treatment led to Sp1 and RNA polymerase II binding to other TSAactivated promoters (Schnur et al., 2007). Therefore, it would be of interest to test whether TSA restores Sp1 binding to the p21 promoter after infection and thus induces p21 transcription.

TSA-treatment only moderately increased mRNA levels of p21 after infection. It should be taken into account, however, that TSA did not induce acetylation of p53 at Lys382 in infected cells (data not shown). This acetylation is possibly required for p53 to be able to activate $p 21$ transcription synergistically with Sp1. Another HDAC inhibitor depsipeptide was described to acetylate p53 at Lys382 and activate p21 expression through both p53 and Sp1 pathways in A549 cells (Zhao et al., 2006). It seems therefore interesting to apply depsipeptide, to see whether it induces the acetylation of p53 and activation of p53 target gene transcription after infection. 


\subsection{Evolutionary advantage for viruses with multiple mechanisms for p53 inactivation}

The mechanisms of p53 inactivation after adenovirus infection through direct binding by E1B-55 kDa and degradation mediated by E4-34 kDa have long been known. This study provides at least two additional ones: transcriptional inactivation by E1A-CR3 and impaired acetylation due to the amino-terminal region of E1A. This scenario raises the question whether the parallel existence of these mechanisms still provides an evolutionary advantage to the virus. Possibly, such advantages only become evident in the context of infected tissue, with intact immune responses and associated proapoptotic mechanisms.

Indirect mechanisms to inactivate p53 are prevalent in other viruses, too. Many nononcogenic human papillomaviruses lack the ability to degrade p53 through their E6 gene products but still survived during evolution. In these cases, indirect p53 inactivation by interaction of E7 with p300 may prevent cell death (Bernat et al., 2003). Herpes virus family members do not directly antagonize p53 either, but at least in the case of cytomegalovirus (human herpes virus type 5), the virus protein IE2 binds p300 and thus inhibits p53 activity (Hsu et al., 2004). The tat protein of human immunodeficiency virus (HIV) also binds p300 and PCAF, and it attenuates p53 activity (Harrod et al., 2003; Wong et al., 2005). Such indirect mechanisms may therefore have evolved earlier than direct p53 antagonisms, and may suffice to avoid p53-induced cell death in many cases. Only a subset of viruses may have developed additional, direct targeting of p53, resulting in enhanced oncogenicity.

\subsection{A role of p53 for oncolytic virus selectivity}

Adenoviruses lacking the interaction between E1B-55 kDa and p53 have been examined for a long time as to their ability to replicate selectively in tumor cells with impaired p53 function, but with limited success. The prototype virus employed for this purpose (Bischoff et al., 1996) was later shown to display selectivity for some tumor cells, but not based on p53 activity. Rather, it takes advantage of differential mRNA 
export (O'Shea et al., 2005). The results presented here provide an explanation why the lack of E1B-55 kDa cannot be expected to result in p53-selective cytotoxicity. The question remains whether, using the knowledge provided by this study, it will be possible to create a virus replicating preferentially in p53-mutant versus p53 wild type cells. Unfortunately, the regions of E1A proteins that are responsible for blocking p53 activity are also critical for regulation of virus replication. Therefore, mutations leading to activation of p53 after infection may simultaneously reduce virus spread in tissues and hence result in a tumor-selective but generally attenuated virus with limited therapeutic use.

\subsection{Open questions}

As frequently encountered in science, there are more questions raised than answers obtained. It would be of great interest to thoroughly test the post-translational status of p53 after infection, to get more information about inactivating and/or lack of activating p53 modifications. It might be helpful to assess whether acetylation of p53 at Lys382, as found with E1A-N-terminal mutants, correlates with increased p53-binding activity to its target promoters, and whether this is applied to the majority of p53 target genes or just some of them. That may clarify, whether we have already found the virus mutant allowing a maximum of p53 DNA-binding activity, or whether this can still be improved. Finally, it is also important to know whether the detachment of Sp1 from the p21

promoter also applies to the other p53 target promoters, containing Sp1-sites. Even of higher importance in terms of p53-selective oncolytic therapy is to test whether E1A still blocks Sp1-mediated p21 transcription in p53 null cells. 


\subsection{Summary}

This study provides additional mechanistic explanations of how adenovirus inactivates p53 function. To summarize, we conclude that in the absence of the well-known p53 inhibitor E1B-55 kDa, adenovirus still is able to block p53 activity in several ways (Fig. 25):

1. By inhibiting acetylation of $p 53$ at Lys382 residue via $\mathrm{N}$-terminus of $\mathrm{E} 1 \mathrm{~A}$ protein

2. By blocking the transcription of $p 53$ target genes via CR3 domain of the large E1A$13 S$ protein

3. By inhibiting protein accumulation of p53 target gene products via $\mathrm{N}$-terminus and CR2 domain of E1A

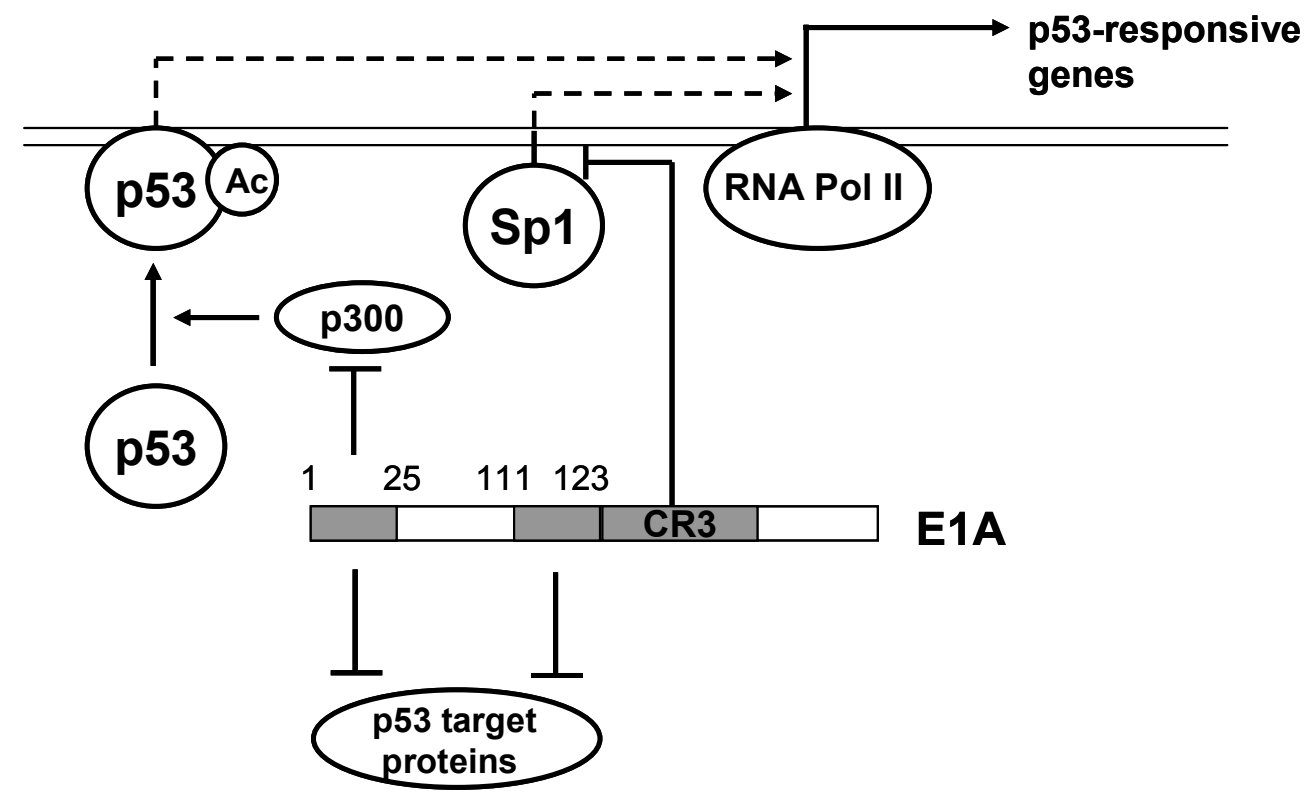

Fig. 25. The model of regulation of the p53 activity by adenovirus. Three distinct domains of E1A independently interfere with p53-mediated transcription, blocking p53 acetylation, Sp1-DNA interaction and accumulation of p53 target proteins. 
Adenovirus apparently evolved these multiple back up mechanisms of p53 inactivation to disrupt the multi-component p53 signalling network that otherwise would trigger cell cycle arrest, senescence or premature apoptosis after infection.

However, even in the case of mutant viruses which lack all these p53-inhibiting E1A activities (for example, d11101 virus), we still observe less induction of p21 transcription than upon treatment with the DNA-damaging drug camptothecin. This suggests additional mechanisms that adenovirus applies to block p53, and those remain to be explored. 


\section{References}

An, W., Kim, J. and Roeder, R.G. (2004) Ordered cooperative functions of PRMT1, p300, and CARM1 in transcriptional activation by p53. Cell, 117, 735-748.

Appella, E. and Anderson, C.W. (2001) Post-translational modifications and activation of p53 by genotoxic stresses. Eur J Biochem, 268, 2764-2772.

Atz, J., Wagner, P. and Roemer, K. (2000) Function, oligomerization, and conformation of tumor-associated p53 proteins with mutated C-terminus. J Cell Biochem, 76, 572-584.

Avantaggiati, M.L., Ogryzko, V., Gardner, K., Giordano, A., Levine, A.S. and Kelly, K. (1997) Recruitment of p300/CBP in p53-dependent signal pathways. Cell, 89, 1175-1184.

Ayed, A., Mulder, F.A., Yi, G.S., Lu, Y., Kay, L.E. and Arrowsmith, C.H. (2001) Latent and active p53 are identical in conformation. Nat Struct Biol, 8, 756-760.

Babiss, L.E. and Ginsberg, H.S. (1984) Adenovirus type 5 early region $1 \mathrm{~b}$ gene product is required for efficient shutoff of host protein synthesis. J Virol, 50, 202-212.

Babiss, L.E., Ginsberg, H.S. and Darnell, J.E., Jr. (1985) Adenovirus E1B proteins are required for accumulation of late viral mRNA and for effects on cellular mRNA translation and transport. Mol Cell Biol, 5, 2552-2558.

Barker, D.D. and Berk, A.J. (1987) Adenovirus proteins from both E1B reading frames are required for transformation of rodent cells by viral infection and DNA transfection. Virology, 156, 107-121.

Barlev, N.A., Liu, L., Chehab, N.H., Mansfield, K., Harris, K.G., Halazonetis, T.D. and Berger, S.L. (2001) Acetylation of p53 activates transcription through recruitment of coactivators/histone acetyltransferases. Mol Cell, 8, 1243-1254.

Beckerman, R., Donner, A.J., Mattia, M., Peart, M.J., Manley, J.L., Espinosa, J.M. and Prives, C. (2009) A role for Chk1 in blocking transcriptional elongation of p21 RNA during the S-phase checkpoint. Genes Dev, 23, 1364-1377.

Ben-Israel, H. and Kleinberger, T. (2002) Adenovirus and cell cycle control. Front Biosci, 7, d1369-1395.

Berk, A.J. (2005) Recent lessons in gene expression, cell cycle control, and cell biology from adenovirus. Oncogene, 24, 7673-7685.

Bernat, A., Avvakumov, N., Mymryk, J.S. and Banks, L. (2003) Interaction between the HPV E7 oncoprotein and the transcriptional coactivator p300. Oncogene, 22, 7871-7881.

Bischoff, J.R., Kirn, D.H., Williams, A., Heise, C., Horn, S., Muna, M., Ng, L., Nye, J.A., Sampson-Johannes, A., Fattaey, A. and McCormick, F. (1996) An adenovirus mutant that replicates selectively in p53-deficient human tumor cells. Science, 274, 373-376.

Bode, A.M. and Dong, Z. (2004) Post-translational modification of p53 in tumorigenesis. Nat Rev Cancer, 4, 793-805.

Bond, G.L., Hu, W., Bond, E.E., Robins, H., Lutzker, S.G., Arva, N.C., Bargonetti, J., Bartel, F., Taubert, H., Wuerl, P., Onel, K., Yip, L., Hwang, S.J., Strong, L.C., Lozano, G. and Levine, A.J. (2004) A single nucleotide polymorphism in the MDM2 promoter attenuates the p53 tumor suppressor pathway and accelerates tumor formation in humans. Cell, 119, 591-602. 
Bourdon, J.C., Renzing, J., Robertson, P.L., Fernandes, K.N. and Lane, D.P. (2002) Scotin, a novel p53-inducible proapoptotic protein located in the ER and the nuclear membrane. J Cell Biol, 158, 235-246.

Boyd, J.M., Malstrom, S., Subramanian, T., Venkatesh, L.K., Schaeper, U., Elangovan, B., D'Sa-Eipper, C. and Chinnadurai, G. (1994) Adenovirus E1B $19 \mathrm{kDa}$ and Bcl2 proteins interact with a common set of cellular proteins. Cell, 79, 341-351.

Bridge, E. and Ketner, G. (1990) Interaction of adenoviral E4 and E1b products in late gene expression. Virology, 174, 345-353.

Brown, J.P., Wei, W. and Sedivy, J.M. (1997) Bypass of senescence after disruption of p21CIP1/WAF1 gene in normal diploid human fibroblasts. Science, 277, 831-834.

Brugarolas, J., Moberg, K., Boyd, S.D., Taya, Y., Jacks, T. and Lees, J.A. (1999) Inhibition of cyclin-dependent kinase 2 by p21 is necessary for retinoblastoma protein-mediated G1 arrest after gamma-irradiation. Proc Natl Acad Sci U S A, 96, 1002-1007.

Bulavin, D.V., Demidov, O.N., Saito, S., Kauraniemi, P., Phillips, C., Amundson, S.A., Ambrosino, C., Sauter, G., Nebreda, A.R., Anderson, C.W., Kallioniemi, A., Fornace, A.J., Jr. and Appella, E. (2002) Amplification of PPM1D in human tumors abrogates p53 tumor-suppressor activity. Nat Genet, 31, 210-215.

Byrd, P.J., Grand, R.J. and Gallimore, P.H. (1988) Differential transformation of primary human embryo retinal cells by adenovirus $\mathrm{E} 1$ regions and combinations of $\mathrm{E} 1 \mathrm{~A}+$ ras. Oncogene, 2, 477-484.

Cathomen, T., Naim, H.Y. and Cattaneo, R. (1998) Measles viruses with altered envelope protein cytoplasmic tails gain cell fusion competence. J Virol, 72, 12241234.

Chen, D., Kon, N., Li, M., Zhang, W., Qin, J. and Gu, W. (2005) ARF-BP1/Mule is a critical mediator of the ARF tumor suppressor. Cell, 121, 1071-1083.

Chin, L., Merlino, G. and DePinho, R.A. (1998) Malignant melanoma: modern black plague and genetic black box. Genes Dev, 12, 3467-3481.

D'Orazi, G., Cecchinelli, B., Bruno, T., Manni, I., Higashimoto, Y., Saito, S., Gostissa, M., Coen, S., Marchetti, A., Del Sal, G., Piaggio, G., Fanciulli, M., Appella, E. and Soddu, S. (2002) Homeodomain-interacting protein kinase-2 phosphorylates p53 at Ser 46 and mediates apoptosis. Nat Cell Biol, 4, 11-19.

Debbas, M. and White, E. (1993) Wild-type p53 mediates apoptosis by E1A, which is inhibited by E1B. Genes Dev, 7, 546-554.

DeLeo, A.B., Jay, G., Appella, E., Dubois, G.C., Law, L.W. and Old, L.J. (1979) Detection of a transformation-related antigen in chemically induced sarcomas and other transformed cells of the mouse. Proc Natl Acad Sci U S A, 76, 2420-2424.

Deng, Y., Chan, S.S. and Chang, S. (2008) Telomere dysfunction and tumour suppression: the senescence connection. Nat Rev Cancer, 8, 450-458.

Dobner, T. and Kzhyshkowska, J. (2001) Nuclear export of adenovirus RNA. Curr Top Microbiol Immunol, 259, 25-54.

Dornan, D., Wertz, I., Shimizu, H., Arnott, D., Frantz, G.D., Dowd, P., O'Rourke, K., Koeppen, H. and Dixit, V.M. (2004) The ubiquitin ligase COP1 is a critical negative regulator of $\mathrm{p} 53$. Nature, 429, 86-92.

Dulic, V., Kaufmann, W.K., Wilson, S.J., Tlsty, T.D., Lees, E., Harper, J.W., Elledge, S.J. and Reed, S.I. (1994) p53-dependent inhibition of cyclin-dependent kinase 
activities in human fibroblasts during radiation-induced $\mathrm{G} 1$ arrest. Cell, 76, 10131023.

el-Deiry, W.S., Harper, J.W., O'Connor, P.M., Velculescu, V.E., Canman, C.E., Jackman, J., Pietenpol, J.A., Burrell, M., Hill, D.E., Wang, Y. and et al. (1994) WAF1/CIP1 is induced in p53-mediated G1 arrest and apoptosis. Cancer Res, 54, 1169-1174.

el-Deiry, W.S., Kern, S.E., Pietenpol, J.A., Kinzler, K.W. and Vogelstein, B. (1992) Definition of a consensus binding site for p53. Nat Genet, 1, 45-49.

el-Deiry, W.S., Tokino, T., Velculescu, V.E., Levy, D.B., Parsons, R., Trent, J.M., Lin, D., Mercer, W.E., Kinzler, K.W. and Vogelstein, B. (1993) WAF1, a potential mediator of p53 tumor suppression. Cell, 75, 817-825.

Ewen, M.E., Xing, Y.G., Lawrence, J.B. and Livingston, D.M. (1991) Molecular cloning, chromosomal mapping, and expression of the cDNA for p107, a retinoblastoma gene product-related protein. Cell, 66, 1155-1164.

Faiola, F., Liu, X., Lo, S., Pan, S., Zhang, K., Lymar, E., Farina, A. and Martinez, E. (2005) Dual regulation of c-Myc by p300 via acetylation-dependent control of Myc protein turnover and coactivation of Myc-induced transcription. Mol Cell Biol, 25, 10220-10234.

Fattaey, A.R., Harlow, E. and Helin, K. (1993) Independent regions of adenovirus E1A are required for binding to and dissociation of E2F-protein complexes. Mol Cell Biol, 13, 7267-7277.

Feng, L., Lin, T., Uranishi, H., Gu, W. and Xu, Y. (2005) Functional analysis of the roles of posttranslational modifications at the p53 C terminus in regulating p53 stability and activity. Mol Cell Biol, 25, 5389-5395.

Friborg, J., Jr., Kong, W., Hottiger, M.O. and Nabel, G.J. (1999) p53 inhibition by the LANA protein of KSHV protects against cell death. Nature, 402, 889-894.

Frisch, S.M. and Mymryk, J.S. (2002) Adenovirus-5 E1A: paradox and paradigm. Nat Rev Mol Cell Biol, 3, 441-452.

Gallimore, P.H. and Turnell, A.S. (2001) Adenovirus E1A: remodelling the host cell, a life or death experience. Oncogene, 20, 7824-7835.

Gartel, A.L. and Tyner, A.L. (1999) Transcriptional regulation of the p21((WAF1/CIP1)) gene. Exp Cell Res, 246, 280-289.

Gartel, A.L., Ye, X., Goufman, E., Shianov, P., Hay, N., Najmabadi, F. and Tyner, A.L. (2001) Myc represses the p21(WAF1/CIP1) promoter and interacts with Sp1/Sp3. Proc Natl Acad Sci U S A, 98, 4510-4515.

Ghosh, M.K. and Harter, M.L. (2003) A viral mechanism for remodeling chromatin structure in $\mathrm{G0}$ cells. Mol Cell, 12, 255-260.

Goodman, R.H. and Smolik, S. (2000) CBP/p300 in cell growth, transformation, and development. Genes Dev, 14, 1553-1577.

Goodrum, F.D. and Ornelles, D.A. (1998) p53 status does not determine outcome of E1B 55-kilodalton mutant adenovirus lytic infection. J Virol, 72, 9479-9490.

Graham, F.L., van der Eb, A.J. and Heijneker, H.L. (1974) Size and location of the transforming region in human adenovirus type 5 DNA. Nature, 251, 687-691.

Grand, R.J., Ibrahim, A.P., Taylor, A.M., Milner, A.E., Gregory, C.D., Gallimore, P.H. and Turnell, A.S. (1998) Human cells arrest in $S$ phase in response to adenovirus 12 E1A. Virology, 244, 330-342. 
Grossman, S.R., Deato, M.E., Brignone, C., Chan, H.M., Kung, A.L., Tagami, H., Nakatani, Y. and Livingston, D.M. (2003) Polyubiquitination of p53 by a ubiquitin ligase activity of p300. Science, 300, 342-344.

Gu, W., Malik, S., Ito, M., Yuan, C.X., Fondell, J.D., Zhang, X., Martinez, E., Qin, J. and Roeder, R.G. (1999) A novel human SRB/MED-containing cofactor complex, SMCC, involved in transcription regulation. Mol Cell, 3, 97-108.

Gu, W. and Roeder, R.G. (1997) Activation of p53 sequence-specific DNA binding by acetylation of the p53 C-terminal domain. Cell, 90, 595-606.

Hainaut, P. and Hollstein, M. (2000) p53 and human cancer: the first ten thousand mutations. Adv Cancer Res, 77, 81-137.

Hammond, E.M., Denko, N.C., Dorie, M.J., Abraham, R.T. and Giaccia, A.J. (2002) Hypoxia links ATR and p53 through replication arrest. Mol Cell Biol, 22, 18341843.

Han, J., Modha, D. and White, E. (1998) Interaction of E1B 19K with Bax is required to block Bax-induced loss of mitochondrial membrane potential and apoptosis. Oncogene, 17, 2993-3005.

Harada, J.N. and Berk, A.J. (1999) p53-Independent and -dependent requirements for E1B-55K in adenovirus type 5 replication. J Virol, 73, 5333-5344.

Harlow, E., Whyte, P., Franza, B.R., Jr. and Schley, C. (1986) Association of adenovirus early-region 1A proteins with cellular polypeptides. Mol Cell Biol, 6, 1579-1589.

Harper, J.W., Adami, G.R., Wei, N., Keyomarsi, K. and Elledge, S.J. (1993) The p21 Cdk-interacting protein Cip1 is a potent inhibitor of G1 cyclin-dependent kinases. Cell, 75, 805-816.

Harper, J.W., Elledge, S.J., Keyomarsi, K., Dynlacht, B., Tsai, L.H., Zhang, P., Dobrowolski, S., Bai, C., Connell-Crowley, L., Swindell, E. and et al. (1995) Inhibition of cyclin-dependent kinases by p21. Mol Biol Cell, 6, 387-400.

Harrod, R., Nacsa, J., Van Lint, C., Hansen, J., Karpova, T., McNally, J. and Franchini, G. (2003) Human immunodeficiency virus type-1 Tat/co-activator acetyltransferase interactions inhibit p53Lys-320 acetylation and p53-responsive transcription. J Biol Chem, 278, 12310-12318.

Haupt, Y., Maya, R., Kazaz, A. and Oren, M. (1997) Mdm2 promotes the rapid degradation of p53. Nature, 387, 296-299.

Heise, C., Sampson-Johannes, A., Williams, A., McCormick, F., Von Hoff, D.D. and Kirn, D.H. (1997) ONYX-015, an E1B gene-attenuated adenovirus, causes tumorspecific cytolysis and antitumoral efficacy that can be augmented by standard chemotherapeutic agents. Nat Med, 3, 639-645.

Hiebert, S.W. (1993) Regions of the retinoblastoma gene product required for its interaction with the E2F transcription factor are necessary for E2 promoter repression and pRb-mediated growth suppression. Mol Cell Biol, 13, 3384-3391.

Hiebert, S.W., Chellappan, S.P., Horowitz, J.M. and Nevins, J.R. (1992) The interaction of RB with E2F coincides with an inhibition of the transcriptional activity of E2F. Genes Dev, 6, 177-185.

Hobom, U. and Dobbelstein, M. (2004) E1B-55-kilodalton protein is not required to block p53-induced transcription during adenovirus infection. J Virol, 78, 7685-7697.

Hoffman, W.H., Biade, S., Zilfou, J.T., Chen, J. and Murphy, M. (2002) Transcriptional repression of the anti-apoptotic survivin gene by wild type p53. J Biol Chem, 277, 3247-3257. 
Honda, R., Tanaka, H. and Yasuda, H. (1997) Oncoprotein MDM2 is a ubiquitin ligase E3 for tumor suppressor p53. FEBS Lett, 420, 25-27.

Houweling, A., van den Elsen, P.J. and van der Eb, A.J. (1980) Partial transformation of primary rat cells by the leftmost $4.5 \%$ fragment of adenovirus 5 DNA. Virology, 105, 537-550.

Hsu, C.H., Chang, M.D., Tai, K.Y., Yang, Y.T., Wang, P.S., Chen, C.J., Wang, Y.H., Lee, S.C., Wu, C.W. and Juan, L.J. (2004) HCMV IE2-mediated inhibition of HAT activity downregulates p53 function. Embo J, 23, 2269-2280.

Huibregtse, J.M., Scheffner, M. and Howley, P.M. (1991) A cellular protein mediates association of p53 with the E6 oncoprotein of human papillomavirus types 16 or 18. Embo J, 10, 4129-4135.

Ito, A., Lai, C.H., Zhao, X., Saito, S., Hamilton, M.H., Appella, E. and Yao, T.P. (2001) p300/CBP-mediated p53 acetylation is commonly induced by p53-activating agents and inhibited by MDM2. Embo J, 20, 1331-1340.

lyer, N.G., Ozdag, H. and Caldas, C. (2004) p300/CBP and cancer. Oncogene, 23, 4225-4231.

Jones, N. and Shenk, T. (1979) Isolation of adenovirus type 5 host range deletion mutants defective for transformation of rat embryo cells. Cell, 17, 683-689.

Jones, S.N., Roe, A.E., Donehower, L.A. and Bradley, A. (1995) Rescue of embryonic lethality in Mdm2-deficient mice by absence of p53. Nature, 378, 206-208.

Kaczmarek, L., Ferguson, B., Rosenberg, M. and Baserga, R. (1986) Induction of cellular DNA synthesis by purified adenovirus E1A proteins. Virology, 152, 1-10.

Kannan, K., Kaminski, N., Rechavi, G., Jakob-Hirsch, J., Amariglio, N. and Givol, D. (2001) DNA microarray analysis of genes involved in p53 mediated apoptosis: activation of Apaf-1. Oncogene, 20, 3449-3455.

Kao, C.C., Yew, P.R. and Berk, A.J. (1990) Domains required for in vitro association between the cellular p53 and the adenovirus 2 E1B 55K proteins. Virology, 179, 806-814.

Keblusek, P., Dorsman, J.C., Teunisse, A.F., Teunissen, H., van der Eb, A.J. and Zantema, A. (1999) The adenoviral E1A oncoproteins interfere with the growthinhibiting effect of the cdk-inhibitor p21(CIP1/WAF1). J Gen Virol, 80 ( Pt 2), 381390.

Kirn, D. (2001) Clinical research results with dl1520 (Onyx-015), a replication-selective adenovirus for the treatment of cancer: what have we learned? Gene Ther, 8, 8998.

Knights, C.D., Catania, J., Di Giovanni, S., Muratoglu, S., Perez, R., Swartzbeck, A., Quong, A.A., Zhang, X., Beerman, T., Pestell, R.G. and Avantaggiati, M.L. (2006) Distinct p53 acetylation cassettes differentially influence gene-expression patterns and cell fate. J Cell Biol, 173, 533-544.

Kortlever, R.M., Higgins, P.J. and Bernards, R. (2006) Plasminogen activator inhibitor-1 is a critical downstream target of p53 in the induction of replicative senescence. Nat Cell Biol, 8, 877-884.

Koumenis, C., Alarcon, R., Hammond, E., Sutphin, P., Hoffman, W., Murphy, M., Derr, J., Taya, Y., Lowe, S.W., Kastan, M. and Giaccia, A. (2001) Regulation of p53 by hypoxia: dissociation of transcriptional repression and apoptosis from p53dependent transactivation. Mol Cell Biol, 21, 1297-1310. 
Koutsodontis, G. and Kardassis, D. (2004) Inhibition of p53-mediated transcriptional responses by mithramycin A. Oncogene, 23, 9190-9200.

Koutsodontis, G., Tentes, I., Papakosta, P., Moustakas, A. and Kardassis, D. (2001) Sp1 plays a critical role in the transcriptional activation of the human cyclin-dependent kinase inhibitor p21(WAF1/Cip1) gene by the p53 tumor suppressor protein. $J$ Biol Chem, 276, 29116-29125.

Koutsodontis, G., Vasilaki, E., Chou, W.C., Papakosta, P. and Kardassis, D. (2005) Physical and functional interactions between members of the tumour suppressor p53 and the Sp families of transcription factors: importance for the regulation of genes involved in cell-cycle arrest and apoptosis. Biochem J, 389, 443-455.

Krause, K., Wasner, M., Reinhard, W., Haugwitz, U., Dohna, C.L., Mossner, J. and Engeland, K. (2000) The tumour suppressor protein p53 can repress transcription of cyclin B. Nucleic Acids Res, 28, 4410-4418.

Kress, M., May, E., Cassingena, R. and May, P. (1979) Simian virus 40-transformed cells express new species of proteins precipitable by anti-simian virus 40 tumor serum. J Virol, 31, 472-483.

Kruse, J.P. and Gu, W. (2009) Modes of p53 regulation. Cell, 137, 609-622.

Kubbutat, M.H., Jones, S.N. and Vousden, K.H. (1997) Regulation of p53 stability by Mdm2. Nature, 387, 299-303.

Lagger, G., Doetzlhofer, A., Schuettengruber, B., Haidweger, E., Simboeck, E., Tischler, J., Chiocca, S., Suske, G., Rotheneder, H., Wintersberger, E. and Seiser, C. (2003) The tumor suppressor p53 and histone deacetylase 1 are antagonistic regulators of the cyclin-dependent kinase inhibitor p21/WAF1/CIP1 gene. Mol Cell Biol, 23, 2669-2679.

Lane, D.P. and Crawford, L.V. (1979) T antigen is bound to a host protein in SV40transformed cells. Nature, 278, 261-263.

Laronga, C., Yang, H.Y., Neal, C. and Lee, M.H. (2000) Association of the cyclindependent kinases and 14-3-3 sigma negatively regulates cell cycle progression. $\mathrm{J}$ Biol Chem, 275, 23106-23112.

Lee, D., Kim, J.W., Seo, T., Hwang, S.G., Choi, E.J. and Choe, J. (2002) SWI/SNF complex interacts with tumor suppressor p53 and is necessary for the activation of p53-mediated transcription. J Biol Chem, 277, 22330-22337.

Leng, R.P., Lin, Y., Ma, W., Wu, H., Lemmers, B., Chung, S., Parant, J.M., Lozano, G., Hakem, R. and Benchimol, S. (2003) Pirh2, a p53-induced ubiquitin-protein ligase, promotes $\mathrm{p} 53$ degradation. Cell, 112, 779-791.

Leppard, K.N. and Shenk, T. (1989) The adenovirus E1B 55 kd protein influences mRNA transport via an intranuclear effect on RNA metabolism. Embo J, 8, 23292336.

Li, M., Brooks, C.L., Wu-Baer, F., Chen, D., Baer, R. and Gu, W. (2003) Mono- versus polyubiquitination: differential control of p53 fate by Mdm2. Science, 302, 19721975.

Li, Y., Graham, C., Lacy, S., Duncan, A.M. and Whyte, P. (1993) The adenovirus E1Aassociated $130-k D$ protein is encoded by a member of the retinoblastoma gene family and physically interacts with cyclins A and E. Genes Dev, 7, 2366-2377.

Li, Z., Day, C.P., Yang, J.Y., Tsai, W.B., Lozano, G., Shih, H.M. and Hung, M.C. (2004) Adenoviral E1A targets Mdm4 to stabilize tumor suppressor p53. Cancer Res, 64, 9080-9085. 
Lill, N.L., Grossman, S.R., Ginsberg, D., DeCaprio, J. and Livingston, D.M. (1997) Binding and modulation of p53 by p300/CBP coactivators. Nature, 387, 823-827.

Lin, H.J., Eviner, V., Prendergast, G.C. and White, E. (1995) Activated H-ras rescues E1A-induced apoptosis and cooperates with E1A to overcome p53-dependent growth arrest. Mol Cell Biol, 15, 4536-4544.

Linzer, D.I. and Levine, A.J. (1979) Characterization of a 54K dalton cellular SV40 tumor antigen present in SV40-transformed cells and uninfected embryonal carcinoma cells. Cell, 17, 43-52.

Liu, F. and Green, M.R. (1994) Promoter targeting by adenovirus E1a through interaction with different cellular DNA-binding domains. Nature, 368, 520-525.

Liu, L., Scolnick, D.M., Trievel, R.C., Zhang, H.B., Marmorstein, R., Halazonetis, T.D. and Berger, S.L. (1999) p53 sites acetylated in vitro by PCAF and p300 are acetylated in vivo in response to DNA damage. Mol Cell Biol, 19, 1202-1209.

Liu, X., Miller, C.W., Koeffler, P.H. and Berk, A.J. (1993) The p53 activation domain binds the TATA box-binding polypeptide in Holo-TFIID, and a neighboring p53 domain inhibits transcription. Mol Cell Biol, 13, 3291-3300.

Logan, J. and Shenk, T. (1984) Adenovirus tripartite leader sequence enhances translation of mRNAs late after infection. Proc Natl Acad Sci U S A, 81, 36553659.

Lohrum, M.A., Woods, D.B., Ludwig, R.L., Balint, E. and Vousden, K.H. (2001) Cterminal ubiquitination of p53 contributes to nuclear export. Mol Cell Biol, 21, 8521-8532.

Lomax, M.E., Barnes, D.M., Hupp, T.R., Picksley, S.M. and Camplejohn, R.S. (1998) Characterization of p53 oligomerization domain mutations isolated from $\mathrm{Li}$ Fraumeni and Li-Fraumeni like family members. Oncogene, 17, 643-649.

Lowe, S.W. and Ruley, H.E. (1993) Stabilization of the p53 tumor suppressor is induced by adenovirus $5 \mathrm{E} 1 \mathrm{~A}$ and accompanies apoptosis. Genes Dev, 7, 535-545.

Luo, J., Li, M., Tang, Y., Laszkowska, M., Roeder, R.G. and Gu, W. (2004) Acetylation of p53 augments its site-specific DNA binding both in vitro and in vivo. Proc Natl Acad Sci U S A, 101, 2259-2264.

Luo, J., Su, F., Chen, D., Shiloh, A. and Gu, W. (2000) Deacetylation of p53 modulates its effect on cell growth and apoptosis. Nature, 408, 377-381.

Luo, R.X., Postigo, A.A. and Dean, D.C. (1998) Rb interacts with histone deacetylase to repress transcription. Cell, 92, 463-473.

MacLachlan, T.K. and El-Deiry, W.S. (2002) Apoptotic threshold is lowered by p53 transactivation of caspase-6. Proc Natl Acad Sci U S A, 99, 9492-9497.

Marchenko, N.D., Wolff, S., Erster, S., Becker, K. and Moll, U.M. (2007) Monoubiquitylation promotes mitochondrial p53 translocation. Embo J, 26, 923934.

Martin, M.E. and Berk, A.J. (1998) Adenovirus E1B 55K represses p53 activation in vitro. J Virol, 72, 3146-3154.

Martin, M.E. and Berk, A.J. (1999) Corepressor required for adenovirus E1B 55,000molecular-weight protein repression of basal transcription. Mol Cell Biol, 19, 3403-3414.

Mattia, M., Gottifredi, V., McKinney, K. and Prives, C. (2007) p53-Dependent p21 mRNA elongation is impaired when DNA replication is stalled. Mol Cell Biol, 27, 13091320. 
Melchior, F. and Hengst, L. (2002) SUMO-1 and p53. Cell Cycle, 1, 245-249.

Mihara, M., Erster, S., Zaika, A., Petrenko, O., Chittenden, T., Pancoska, P. and Moll, U.M. (2003) p53 has a direct apoptogenic role at the mitochondria. Mol Cell, 11, 577-590.

Mihara, M. and Moll, U.M. (2003) Detection of mitochondrial localization of p53. Methods Mol Biol, 234, 203-209.

Miyashita, T., Harigai, M., Hanada, M. and Reed, J.C. (1994a) Identification of a p53dependent negative response element in the bcl-2 gene. Cancer Res, 54, 31313135.

Miyashita, T., Krajewski, S., Krajewska, M., Wang, H.G., Lin, H.K., Liebermann, D.A., Hoffman, B. and Reed, J.C. (1994b) Tumor suppressor p53 is a regulator of bcl-2 and bax gene expression in vitro and in vivo. Oncogene, 9, 1799-1805.

Montes de Oca Luna, R., Wagner, D.S. and Lozano, G. (1995) Rescue of early embryonic lethality in mdm2-deficient mice by deletion of p53. Nature, 378, 203206.

Moroni, M.C., Hickman, E.S., Lazzerini Denchi, E., Caprara, G., Colli, E., Cecconi, F., Muller, H. and Helin, K. (2001) Apaf-1 is a transcriptional target for E2F and p53. Nat Cell Biol, 3, 552-558.

Nakano, K. and Vousden, K.H. (2001) PUMA, a novel proapoptotic gene, is induced by p53. Mol Cell, 7, 683-694.

Nikolaev, A.Y., Li, M., Puskas, N., Qin, J. and Gu, W. (2003) Parc: a cytoplasmic anchor for p53. Cell, 112, 29-40.

O'Shea, C.C. and Fried, M. (2005) Modulation of the ARF-p53 pathway by the small DNA tumor viruses. Cell Cycle, 4, 449-452.

O'Shea, C.C., Johnson, L., Bagus, B., Choi, S., Nicholas, C., Shen, A., Boyle, L., Pandey, K., Soria, C., Kunich, J., Shen, Y., Habets, G., Ginzinger, D. and McCormick, F. (2004) Late viral RNA export, rather than p53 inactivation, determines ONYX-015 tumor selectivity. Cancer Cell, 6, 611-623.

O'Shea, C.C., Soria, C., Bagus, B. and McCormick, F. (2005) Heat shock phenocopies E1B-55K late functions and selectively sensitizes refractory tumor cells to ONYX015 oncolytic viral therapy. Cancer Cell, 8, 61-74.

Oda, E., Ohki, R., Murasawa, H., Nemoto, J., Shibue, T., Yamashita, T., Tokino, T., Taniguchi, T. and Tanaka, N. (2000a) Noxa, a BH3-only member of the Bcl-2 family and candidate mediator of p53-induced apoptosis. Science, 288, 10531058.

Oda, K., Arakawa, H., Tanaka, T., Matsuda, K., Tanikawa, C., Mori, T., Nishimori, H., Tamai, K., Tokino, T., Nakamura, Y. and Taya, Y. (2000b) p53AIP1, a potential mediator of p53-dependent apoptosis, and its regulation by Ser-46phosphorylated p53. Cell, 102, 849-862.

Ohki, R., Nemoto, J., Murasawa, H., Oda, E., Inazawa, J., Tanaka, N. and Taniguchi, T. (2000) Reprimo, a new candidate mediator of the p53-mediated cell cycle arrest at the G2 phase. J Biol Chem, 275, 22627-22630.

Olovnikov, A.M. (1971) [Principle of marginotomy in template synthesis of polynucleotides]. Dokl Akad Nauk SSSR, 201, 1496-1499.

Olovnikov, A.M. (1973) A theory of marginotomy. The incomplete copying of template margin in enzymic synthesis of polynucleotides and biological significance of the phenomenon. J Theor Biol, 41, 181-190. 
Oren, M., Maltzman, W. and Levine, A.J. (1981) Post-translational regulation of the 54K cellular tumor antigen in normal and transformed cells. Mol Cell Biol, 1, 101-110.

Parks, C.L. and Shenk, T. (1997) Activation of the adenovirus major late promoter by transcription factors MAZ and Sp1. J Virol, 71, 9600-9607.

Pilder, S., Moore, M., Logan, J. and Shenk, T. (1986) The adenovirus E1B-55K transforming polypeptide modulates transport or cytoplasmic stabilization of viral and host cell mRNAs. Mol Cell Biol, 6, 470-476.

Putzer, B.M., Stiewe, T., Parssanedjad, K., Rega, S. and Esche, H. (2000) E1A is sufficient by itself to induce apoptosis independent of p53 and other adenoviral gene products. Cell Death Differ, 7, 177-188.

Qin, X.Q., Chittenden, T., Livingston, D.M. and Kaelin, W.G., Jr. (1992) Identification of a growth suppression domain within the retinoblastoma gene product. Genes Dev, 6, 953-964.

Querido, E., Marcellus, R.C., Lai, A., Charbonneau, R., Teodoro, J.G., Ketner, G. and Branton, P.E. (1997) Regulation of p53 levels by the E1B 55-kilodalton protein and E4orf6 in adenovirus-infected cells. J Virol, 71, 3788-3798.

Querido, E., Morrison, M.R., Chu-Pham-Dang, H., Thirlwell, S.W., Boivin, D. and Branton, P.E. (2001) Identification of three functions of the adenovirus e4orf6 protein that mediate p53 degradation by the E4orf6-E1B55K complex. $\mathrm{J}$ Virol, 75, 699-709.

Rekosh, D.M., Russell, W.C., Bellet, A.J. and Robinson, A.J. (1977) Identification of a protein linked to the ends of adenovirus DNA. Cell, 11, 283-295.

Ries, S.J., Brandts, C.H., Chung, A.S., Biederer, C.H., Hann, B.C., Lipner, E.M., McCormick, F. and Korn, W.M. (2000) Loss of p14ARF in tumor cells facilitates replication of the adenovirus mutant dl1520 (ONYX-015). Nat Med, 6, 1128-1133.

Rikhof, B., Corn, P.G. and El-Deiry, W.S. (2003) Caspase 10 levels are increased following DNA damage in a p53-dependent manner. Cancer Biol Ther, 2, 707712.

Ringshausen, I., O'Shea, C.C., Finch, A.J., Swigart, L.B. and Evan, G.I. (2006) Mdm2 is critically and continuously required to suppress lethal p53 activity in vivo. Cancer Cell, 10, 501-514.

Rocha, S., Martin, A.M., Meek, D.W. and Perkins, N.D. (2003) p53 represses cyclin D1 transcription through down regulation of $\mathrm{Bcl}-3$ and inducing increased association of the p52 NF-kappaB subunit with histone deacetylase 1. Mol Cell Biol, 23, 47134727.

Rodriguez, M.S., Desterro, J.M., Lain, S., Lane, D.P. and Hay, R.T. (2000) Multiple Cterminal lysine residues target p53 for ubiquitin-proteasome-mediated degradation. Mol Cell Biol, 20, 8458-8467.

Roth, J. and Dobbelstein, M. (2003) Interaction of p53 with the adenovirus E1B-55 kDa protein. Methods Mol Biol, 234, 135-149.

Roth, J., Konig, C., Wienzek, S., Weigel, S., Ristea, S. and Dobbelstein, M. (1998) Inactivation of p53 but not p73 by adenovirus type 5 E1B 55-kilodalton and E4 34-kilodalton oncoproteins. J Virol, 72, 8510-8516.

Rothmann, T., Hengstermann, A., Whitaker, N.J., Scheffner, M. and zur Hausen, H. (1998) Replication of ONYX-015, a potential anticancer adenovirus, is independent of p53 status in tumor cells. J Virol, 72, 9470-9478. 
Ruley, H.E. (1983) Adenovirus early region $1 \mathrm{~A}$ enables viral and cellular transforming genes to transform primary cells in culture. Nature, 304, 602-606.

Russell, W.C. (2000) Update on adenovirus and its vectors. J Gen Virol, 81, 2573-2604.

Russell, W.C. (2009) Adenoviruses: update on structure and function. J Gen Virol, 90, 120.

Sakaguchi, K., Herrera, J.E., Saito, S., Miki, T., Bustin, M., Vassilev, A., Anderson, C.W. and Appella, E. (1998) DNA damage activates p53 through a phosphorylationacetylation cascade. Genes Dev, 12, 2831-2841.

Sax, J.K., Fei, P., Murphy, M.E., Bernhard, E., Korsmeyer, S.J. and El-Deiry, W.S. (2002) BID regulation by p53 contributes to chemosensitivity. Nat Cell Biol, 4, 842-849.

Scheffner, M., Munger, K., Huibregtse, J.M. and Howley, P.M. (1992) Targeted degradation of the retinoblastoma protein by human papillomavirus E7-E6 fusion proteins. Embo J, 11, 2425-2431.

Scheffner, M., Werness, B.A., Huibregtse, J.M., Levine, A.J. and Howley, P.M. (1990) The E6 oncoprotein encoded by human papillomavirus types 16 and 18 promotes the degradation of p53. Cell, 63, 1129-1136.

Schmidt, M.C., Zhou, Q. and Berk, A.J. (1989) Sp1 activates transcription without enhancing DNA-binding activity of the TATA box factor. Mol Cell Biol, 9, 32993307.

Schnur, N., Seuter, S., Katryniok, C., Radmark, O. and Steinhilber, D. (2007) The histone deacetylase inhibitor trichostatin A mediates upregulation of 5lipoxygenase promoter activity by recruitment of $\mathrm{Sp} 1$ to distinct GC-boxes. Biochim Biophys Acta, 1771, 1271-1282.

Sengupta, S., Vonesch, J.L., Waltzinger, C., Zheng, H. and Wasylyk, B. (2000) Negative cross-talk between p53 and the glucocorticoid receptor and its role in neuroblastoma cells. Embo J, 19, 6051-6064.

Seto, E., Usheva, A., Zambetti, G.P., Momand, J., Horikoshi, N., Weinmann, R., Levine, A.J. and Shenk, T. (1992) Wild-type p53 binds to the TATA-binding protein and represses transcription. Proc Natl Acad Sci U S A, 89, 12028-12032.

Shangary, S., Qin, D., McEachern, D., Liu, M., Miller, R.S., Qiu, S., Nikolovska-Coleska, Z., Ding, K., Wang, G., Chen, J., Bernard, D., Zhang, J., Lu, Y., Gu, Q., Shah, R.B., Pienta, K.J., Ling, X., Kang, S., Guo, M., Sun, Y., Yang, D. and Wang, S. (2008) Temporal activation of p53 by a specific MDM2 inhibitor is selectively toxic to tumors and leads to complete tumor growth inhibition. Proc Natl Acad Sci U S A, 105, 3933-3938.

Shen, Y., Kitzes, G., Nye, J.A., Fattaey, A. and Hermiston, T. (2001) Analyses of singleamino-acid substitution mutants of adenovirus type 5 E1B-55K protein. $J$ Virol, 75, 4297-4307.

Shepherd, S.E., Howe, J.A., Mymryk, J.S. and Bayley, S.T. (1993) Induction of the cell cycle in baby rat kidney cells by adenovirus type $5 \mathrm{E} 1 \mathrm{~A}$ in the absence of E1B and a possible influence of p53. J Virol, 67, 2944-2949.

Sherr, C.J. (2000) The Pezcoller lecture: cancer cell cycles revisited. Cancer Res, 60, 3689-3695.

Shieh, S.Y., Ahn, J., Tamai, K., Taya, Y. and Prives, C. (2000) The human homologs of checkpoint kinases Chk1 and Cds1 (Chk2) phosphorylate p53 at multiple DNA damage-inducible sites. Genes Dev, 14, 289-300. 
Shieh, S.Y., Ikeda, M., Taya, Y. and Prives, C. (1997) DNA damage-induced phosphorylation of p53 alleviates inhibition by MDM2. Cell, 91, 325-334.

Sieber, T. and Dobner, T. (2007) Adenovirus type 5 early region 1B 156R protein promotes cell transformation independently of repression of p53-stimulated transcription. J Virol, 81, 95-105.

Singh, B., Reddy, P.G., Goberdhan, A., Walsh, C., Dao, S., Ngai, I., Chou, T.C., P, O.C., Levine, A.J., Rao, P.H. and Stoffel, A. (2002) p53 regulates cell survival by inhibiting PIK3CA in squamous cell carcinomas. Genes Dev, 16, 984-993.

Sowa, Y., Orita, T., Minamikawa, S., Nakano, K., Mizuno, T., Nomura, H. and Sakai, T. (1997) Histone deacetylase inhibitor activates the WAF1/Cip1 gene promoter through the Sp1 sites. Biochem Biophys Res Commun, 241, 142-150.

Stambolic, V., MacPherson, D., Sas, D., Lin, Y., Snow, B., Jang, Y., Benchimol, S. and Mak, T.W. (2001) Regulation of PTEN transcription by p53. Mol Cell, 8, 317-325.

Steegenga, W.T., Riteco, N., Jochemsen, A.G., Fallaux, F.J. and Bos, J.L. (1998) The large E1B protein together with the E4orf6 protein target p53 for active degradation in adenovirus infected cells. Oncogene, 16, 349-357.

Stommel, J.M. and Wahl, G.M. (2004) Accelerated MDM2 auto-degradation induced by DNA-damage kinases is required for p53 activation. Embo J, 23, 1547-1556.

Sugars, K.L., Budhram-Mahadeo, V., Packham, G. and Latchman, D.S. (2001) A minimal Bcl-x promoter is activated by Brn-3a and repressed by p53. Nucleic Acids Res, 29, 4530-4540.

Sykes, S.M., Mellert, H.S., Holbert, M.A., Li, K., Marmorstein, R., Lane, W.S. and McMahon, S.B. (2006) Acetylation of the p53 DNA-binding domain regulates apoptosis induction. Mol Cell, 24, 841-851.

Taira, N., Nihira, K., Yamaguchi, T., Miki, Y. and Yoshida, K. (2007) DYRK2 is targeted to the nucleus and controls p53 via Ser46 phosphorylation in the apoptotic response to DNA damage. Mol Cell, 25, 725-738.

Takimoto, R. and El-Deiry, W.S. (2000) Wild-type p53 transactivates the KILLER/DR5 gene through an intronic sequence-specific DNA-binding site. Oncogene, 19, 1735-1743.

Tang, Y., Luo, J., Zhang, W. and Gu, W. (2006) Tip60-dependent acetylation of p53 modulates the decision between cell-cycle arrest and apoptosis. Mol Cell, 24, 827-839.

Tanikawa, C., Matsuda, K., Fukuda, S., Nakamura, Y. and Arakawa, H. (2003) p53RDL1 regulates p53-dependent apoptosis. Nat Cell Biol, 5, 216-223.

Taubert, H., Schuster, K., Brinck, U., Bartel, F., Kappler, M., Lautenschlager, C., Bache, M., Trump, C., Schmidt, H., Holzhausen, H.J., Wurl, P. and Schlott, T. (2003) Loss of heterozygosity at 12q14-15 often occurs in stage I soft tissue sarcomas and is associated with MDM2 amplification in tumors at various stages. Mod Pathol, 16, 1109-1116.

Teodoro, J.G., Shore, G.C. and Branton, P.E. (1995) Adenovirus E1A proteins induce apoptosis by both p53-dependent and p53-independent mechanisms. Oncogene, 11, 467-474.

Thomas, M.C. and Chiang, C.M. (2005) E6 oncoprotein represses p53-dependent gene activation via inhibition of protein acetylation independently of inducing p53 degradation. Mol Cell, 17, 251-264. 
Thut, C.J., Chen, J.L., Klemm, R. and Tjian, R. (1995) p53 transcriptional activation mediated by coactivators TAFII40 and TAFII60. Science, 267, 100-104.

Trentin, J.J., Yabe, Y. and Taylor, G. (1962) The quest for human cancer viruses. Science, 137, 835-841.

Truant, R., Xiao, H., Ingles, C.J. and Greenblatt, J. (1993) Direct interaction between the transcriptional activation domain of human p53 and the TATA box-binding protein. J Biol Chem, 268, 2284-2287.

Turnell, A.S., Grand, R.J. and Gallimore, P.H. (1999) The replicative capacities of large E1B-null group A and group C adenoviruses are independent of host cell p53 status. J Virol, 73, 2074-2083.

Turnell, A.S., Grand, R.J., Gorbea, C., Zhang, X., Wang, W., Mymryk, J.S. and Gallimore, P.H. (2000) Regulation of the 26S proteasome by adenovirus E1A. Embo J, 19, 4759-4773.

Vassilev, L.T., Vu, B.T., Graves, B., Carvajal, D., Podlaski, F., Filipovic, Z., Kong, N., Kammlott, U., Lukacs, C., Klein, C., Fotouhi, N. and Liu, E.A. (2004) In vivo activation of the p53 pathway by small-molecule antagonists of MDM2. Science, 303, 844-848.

Weber, J.D., Taylor, L.J., Roussel, M.F., Sherr, C.J. and Bar-Sagi, D. (1999) Nucleolar Arf sequesters Mdm2 and activates p53. Nat Cell Biol, 1, 20-26.

Whyte, P., Buchkovich, K.J., Horowitz, J.M., Friend, S.H., Raybuck, M., Weinberg, R.A. and Harlow, E. (1988) Association between an oncogene and an anti-oncogene: the adenovirus E1A proteins bind to the retinoblastoma gene product. Nature, 334, 124-129.

Wong, K., Sharma, A., Awasthi, S., Matlock, E.F., Rogers, L., Van Lint, C., Skiest, D.J., Burns, D.K. and Harrod, R. (2005) HIV-1 Tat interactions with p300 and PCAF transcriptional coactivators inhibit histone acetylation and neurotrophin signaling through CREB. J Biol Chem, 280, 9390-9399.

Wu, G.S., Burns, T.F., McDonald, E.R., 3rd, Jiang, W., Meng, R., Krantz, I.D., Kao, G., Gan, D.D., Zhou, J.Y., Muschel, R., Hamilton, S.R., Spinner, N.B., Markowitz, S., Wu, G. and el-Deiry, W.S. (1997) KILLER/DR5 is a DNA damage-inducible p53regulated death receptor gene. Nat Genet, 17, 141-143.

Xiong, Y., Hannon, G.J., Zhang, H., Casso, D., Kobayashi, R. and Beach, D. (1993) p21 is a universal inhibitor of cyclin kinases. Nature, 366, 701-704.

Yew, P.R. and Berk, A.J. (1992) Inhibition of p53 transactivation required for transformation by adenovirus early $1 \mathrm{~B}$ protein. Nature, 357, 82-85.

Yew, P.R., Liu, X. and Berk, A.J. (1994) Adenovirus E1B oncoprotein tethers a transcriptional repression domain to p53. Genes Dev, 8, 190-202.

Yu, J., Zhang, L., Hwang, P.M., Kinzler, K.W. and Vogelstein, B. (2001) PUMA induces the rapid apoptosis of colorectal cancer cells. Mol Cell, 7, 673-682.

Yun, J., Chae, H.D., Choy, H.E., Chung, J., Yoo, H.S., Han, M.H. and Shin, D.Y. (1999) p53 negatively regulates cdc2 transcription via the CCAAT-binding NF-Y transcription factor. J Biol Chem, 274, 29677-29682.

Zantema, A., Fransen, J.A., Davis-Olivier, A., Ramaekers, F.C., Vooijs, G.P., DeLeys, B. and Van der Eb, A.J. (1985a) Localization of the E1B proteins of adenovirus 5 in transformed cells, as revealed by interaction with monoclonal antibodies. Virology, 142, 44-58. 
Zantema, A., Schrier, P.I., Davis-Olivier, A., van Laar, T., Vaessen, R.T. and van der, E.A. (1985b) Adenovirus serotype determines association and localization of the large E1B tumor antigen with cellular tumor antigen p53 in transformed cells. Mol Cell Biol, 5, 3084-3091.

Zhan, Q., Antinore, M.J., Wang, X.W., Carrier, F., Smith, M.L., Harris, C.C. and Fornace, A.J., Jr. (1999) Association with Cdc2 and inhibition of Cdc2/Cyclin B1 kinase activity by the p53-regulated protein Gadd45. Oncogene, 18, 2892-2900.

Zhang, H., Xiong, Y. and Beach, D. (1993) Proliferating cell nuclear antigen and p21 are components of multiple cell cycle kinase complexes. Mol Biol Cell, 4, 897-906.

Zhang, X., Krutchinsky, A., Fukuda, A., Chen, W., Yamamura, S., Chait, B.T. and Roeder, R.G. (2005) MED1/TRAP220 exists predominantly in a TRAP/ Mediator subpopulation enriched in RNA polymerase II and is required for ER-mediated transcription. Mol Cell, 19, 89-100.

Zhang, X., Turnell, A.S., Gorbea, C., Mymryk, J.S., Gallimore, P.H. and Grand, R.J. (2004) The targeting of the proteasomal regulatory subunit $S 2$ by adenovirus E1A causes inhibition of proteasomal activity and increased p53 expression. J Biol Chem, 279, 25122-25133.

Zhang, Y. and Xiong, Y. (2001) A p53 amino-terminal nuclear export signal inhibited by DNA damage-induced phosphorylation. Science, 292, 1910-1915.

Zhao, Y., Lu, S., Wu, L., Chai, G., Wang, H., Chen, Y., Sun, J., Yu, Y., Zhou, W., Zheng, Q., Wu, M., Otterson, G.A. and Zhu, W.G. (2006) Acetylation of p53 at lysine $373 / 382$ by the histone deacetylase inhibitor depsipeptide induces expression of p21(Waf1/Cip1). Mol Cell Biol, 26, 2782-2790.

Zheng, L. and Lee, W.H. (2001) The retinoblastoma gene: a prototypic and multifunctional tumor suppressor. Exp Cell Res, 264, 2-18. 


\section{Abbreviations}

Ad

Apaf1

APS

ARF

ARF-BP1

Arg

ATF

ATM

ATR

BAX

Bcl-2

Bid

BSA

CARM1

CBP

Cdc

CDK

CDKN1A

CDNA

ChIP

Chk1,2

$\mathrm{CHX}$

CK2

Cop1

CPT

CR

CT

CtBP

C-terminal

DAPI

DBD

DMEM

DMSO

DNA

DNA-PK

dNTP

DYRK2

E1A

E1B

E2F

E4ORF6

E6AP

EDTA
Adenovirus

Apoptotic protease activating factor 1

Ammonium Persulfate

Alternative Reading Frame

ARF-Binding Protein 1

Arginine

Activating Transcription Factor

Ataxia Telangiectasia Mutated protein

Ataxia Telangiectasia-Related

$\mathrm{Bcl}-2$ Assosciated $\mathrm{X}$ protein

B-Cell CLL/Lymphoma 2

$\mathrm{BH} 3$ Interacting Domain death agonist

Bovine Serum Albumin

Coactivator-Associated arginine Methyltransferase 1

CREB Binding Protein

cell division control protein

Cyclin-Dependent Kinase

Cyclin-Dependent Kinase Inhibitor 1A

complementary Deoxyriboucleic acid

Chromatin Immunoprecipitation

Checkpoint Kinase 1,2

Cycloheximide

Casein Kinase-2

Constitutive photomorphogenic

Camptothecin

Conserved Region

C-terminal domain

C-terminal Binding Protein

Carboxyterminal

4',6'-Diamino-2-phenylindol

DNA-binding domain

Dulbecco's Modified Eagle Medium

Dimethyl sulfoxide

Deoxyribonucleic acid

DNA-dependent Protein Kinase

Deoxynucleotide triphosphate

Dual-Specificity Yak1-Related Kinase 2

Early region $1 \mathrm{~A}$

Early region $1 \mathrm{~B}$

E2 Transcription Factor

E4 region Open Reading Frame 6

E6-associated protein

Ethilene diamine tetraacetate 
FCS

Fig.

$\mathrm{g}$

GADD45

GAPDH

Gly

h

HA

HAT

HDAC

HIPK

hMOF

HPR

HPV

IB

$\lg$

IP

JNK

$\mathrm{K}$

$\mathrm{kb}$

$\mathrm{kDa}$

I

LANA

Lys

$\mathrm{m}$

$M$

Mdm2

$\mathrm{MHC}$

min

MOI

mRNA

MYC

$\mathrm{n}$

Noxa

$\mathrm{N}$-terminal

${ }^{\circ} \mathrm{C}$

p53AIP1

PAGE

PAI-1

PBS

PCAF

PCNA

PCR

PI3K

PIG

Pirh1

PML
Fetal Calf Serum

Figure

gram

Growth Arrest and DNA Damage-45

Glyceraldehyde-3-phosphate-dehydrogenase

Glycine

hours

Hemmaglutinin

Histone Acetyltransferrase

Histone deacetyase

Homeodomain-interacting Protein Kinase

Human ortholog of Drosophila Mof

Horseradish peroxidase

Human papillomavirus

Immunoblot

Immunoglobulin

Immunoprecipitation

Jun-N-terminal Kinase

Lysine

kilobase

kilo Dalton

litre

Latency-associated Nuclear Antigen

Lysine

milli

$\mathrm{Mol} / \mathrm{l}$

Mouse Double Minute 2

Major Histocompatibility Complex

minute(s)

Multiplicity of infection

messenger RNA

Myelocytomatosis oncogene cellular homolog

nano

NADPH oxidase activator 1

aminoterminal

grad Celsius

p53 apoptosis-inducing protein 1

Polyacrilamide Gel Electrophoresis

Plasminogen Activator Inhibitor Type 1

Phosphate Buffered Saline

p300/CBP-associating factor

Proliferating Cell Nuclear Antigen

Polymerase Chain Reaction

Phosphoinositide 3 kinase

p53-induced gene

p53-induced, RING-H2 domain containing

Promyelocytic leucemia protein 


\begin{tabular}{ll} 
pRb & Retinoblastoma protein \\
PRMT1 & Protein arginine N-methyltransferase 1 \\
PRR & Proline Reach Region \\
Pu & Purine \\
PUMA & p53-upregulated Modulator of Apoptosis \\
Py & Pirimidine \\
RNA & Ribonucleic acid \\
rpm & rounds per minute \\
SDS & Sodium Dodecyl Sulfate \\
sec & second(s) \\
Ser & Serine \\
Sp1 & Specificity protein 1 \\
SUMO & Small Ubiquitin like Modifier \\
SV 40 T-ag & Simian Virus 40 T antigen \\
SWI/SNF & Switch/Sucrose Non-Fermentable \\
TAD & Transactivation Domain \\
TAE & Tris-acetic acid \\
TAF & TBP Associated Factor \\
TBP & TATA Binding Protein \\
TEMED & N, N, N', N'Thetramethylendiamine \\
TET & Tetramerization domain \\
TGF- $\beta$ & Transforming Growth Factor $\beta$ \\
Thr & Threonin \\
Tip60 & HIV1 Tat Interacting Protein \\
Tris & 2-amino-2-hydroxymethyl-1,3-propanediol \\
TRRAP & Transformation/transcription domain associated protein \\
TSA & Trichostatin A \\
UV & Ultra Violet \\
V & Volt \\
v/v & volume/volume \\
w/v & weight/volume \\
wt & wild type \\
YY1 & Yin Yang 1 \\
$\Delta$ & delta \\
$\mu$ & micro \\
\hline
\end{tabular}




\section{Curriculum Vitae}

\section{Personal details}

Surname:

Name:

Nationality:

Place of birth:

Marital status:
Savelyeva

Irina

Russian

Saint-Petersburg, Russia

Single

\section{Education}

Since 2005

PhD Thesis in the laboratory of

Prof. Dr. Matthias Dobbelstein

Medical Biotechnology Center, University of Southern Denmark, Odense, Denmark

since December 2005

Göttingen Center for Molecular Biosciences,

Faculty of Medicine, University of Göttingen, Germany

2000-2004

Research laboratory assistant in the laboratory of Dr. Tatiana V. Pospelova Institute of Cytology, Russian Academy of Science Saint-Petersburg, Russia

Graduation from Saint-Petersburg State

Polytechnical University, Saint Petersburg, Russia as a Biophysicist (diploma with honour)

2001-2003

Master of Science in Biophysics

Master thesis in the group of

Dr. Tatiana V. Pospelova

Institute of Cytology, Russian Academy of Science Saint-Petersburg, Russia

Bachelor of Science in Physics

Bachelor thesis in the group of

Dr. Tatiana V. Pospelova

Institute of Cytology, Russian Academy of Science

Saint-Petersburg, Russia 
$1997-2003$

1989-1997

1987-1988
Saint-Petersburg State Polytechnical University, Saint Petersburg, Russia

Secondary school with the extensive learning of English N160

Saint-Petersburg, Russia

Primary school N134

Saint-Petersburg, Russia

\section{Publications}

I. Savelyeva and M. Dobbelstein. Infection with E1B-mutant adenovirus stabilizes p53 but blocks p53 acetylation and activity through E1A, submitted.

C.J. Braun, X. Zhang, I. Savelyeva, S. Wolff, U.M. Moll, T. Schepeler, T.F. Ørntoft, C.L. Andersen and M. Dobbelstein. 2008. p53-Responsive microRNAs 192 and 215 are capable of inducing cell cycle arrest. Cancer Res, 68: 10094-104.

I.A.Savel'eva, T.V. Bykova, N.D. Aksenov, V.A. Pospelov, T.V. Pospelova. 2003. MAP kinase cascades analysis in transformed cells with different abilities to make G1/S block under serum starvation. Tsitologiya, 45: 493-499.

\section{Selected Presentations}

I. Savelyeva and M. Dobbelstein. Multiple mechanisms of p53 inactivation by adenovirus infection. The $2^{\text {nd }}$ Annual Meeting on Cancer and Control of Genomic Integrity, $21^{\text {st }}-23^{\text {rd }}$ August, 2009, Stockholm, Sweeden (oral presentation).

I. Savelyeva and M. Dobbelstein. p53 inactivation by E1B-deleted, oncolytic adenovirus. $15^{\text {th }}$ International AEK Cancer Congress, $18^{\text {th }}-20^{\text {th }}$ March, 2009, Berlin, Germany.

I. Savelyeva and M. Dobbelstein. Beyond E1B - backup mechanisms of p53 inactivation by adenovirus infection. $9^{\text {th }}$ NorFa p53/Cell Cycle Workshop, $15-17^{\text {th }}$ June, 2007, Bergen, Norway (oral presentation). 


\section{Acknowledgements}

The effort and generous help of many people enabled completion of this Doctoral thesis.

Prof. Matthias Dobbelstein, my advisor, was the most important contributor. First of all, I would like to thank Matthias for the opportunity to work in his lab under his supervision. I very much appreciate our long scientific discussions that have helped me to learn a lot and to develop professionally. Our conversations always gave me a lot of inspiration and motivation that are so much important in our business. I must say, I also have been amazingly lucky to have a supervisor who was not only one of the best teachers that I have had in my life, but also very friendly and extremely helpful person. Last, but not the least, I want to thank Matthias for careful reading and correcting this manuscript.

I would like to thank Prof. Tomas Pieler and Prof. Ralf Ficner, the members of my thesis committee, for giving me helpful suggestions on this project. Big thanks to Steve Johnsen for his invaluable ChIP protocol, helpful advices and cheerful character.

This work would not be possible without a help of my dear colleagues. I had an honor to work in two Dobbelsteins' groups: in Odense (Denmark) and in Göttingen (Germany). I would like to thank both teams for being my scientific families during the time of my PhD, for their help in solving research problems and for spiritual support in difficult times. My special thanks go to Magda Morawska-Onyszczuk, Xin Zhang, Muriel Lize, Andrei Shchebet and Andreas Scheel for being always helpful and friendly. I also thank my office mates Ulli Beyer, leva Gailite and Fred Köpper for the lovely everyday working atmosphere.

I am very grateful for the great technical assistance of Anni Peterson, Antje Dickmanns and Cathrin Hippel. I would like also to acknowledge Dr. Joe Mymryk, Dr. Roger Grand and Dr. Xian Zhang for sending the viruses and Dr. Klaus Roemer for the plasmids, used in my study.

Many new friends I have met in Göttingen helped me a lot to integrate and partially substituted me for a family. Special thanks in this regard to Denis Bulatow, Dmitry Bibitchkov, Anton Volkov, and Betina Weege. I sincerely thank them for their warmth, care and believing in me. Very special thanks to my dearest Matthias Theves, whom I was fortunate to meet at the moment of writing this dissertation.

Finally, I want to deeply thank the members of my family. Their love and wise support, their care and believing gave me a lot of energy and courage to start and to finish my study. 
